\title{
Branhamella catarrhalis: an Organism Gaining Respect as a Pathogen
}

\author{
B. WESLEY CATLIN $\dagger$ \\ Department of Microbiology, The Medical College of Wisconsin, Milwaukee, Wisconsin 53226
}

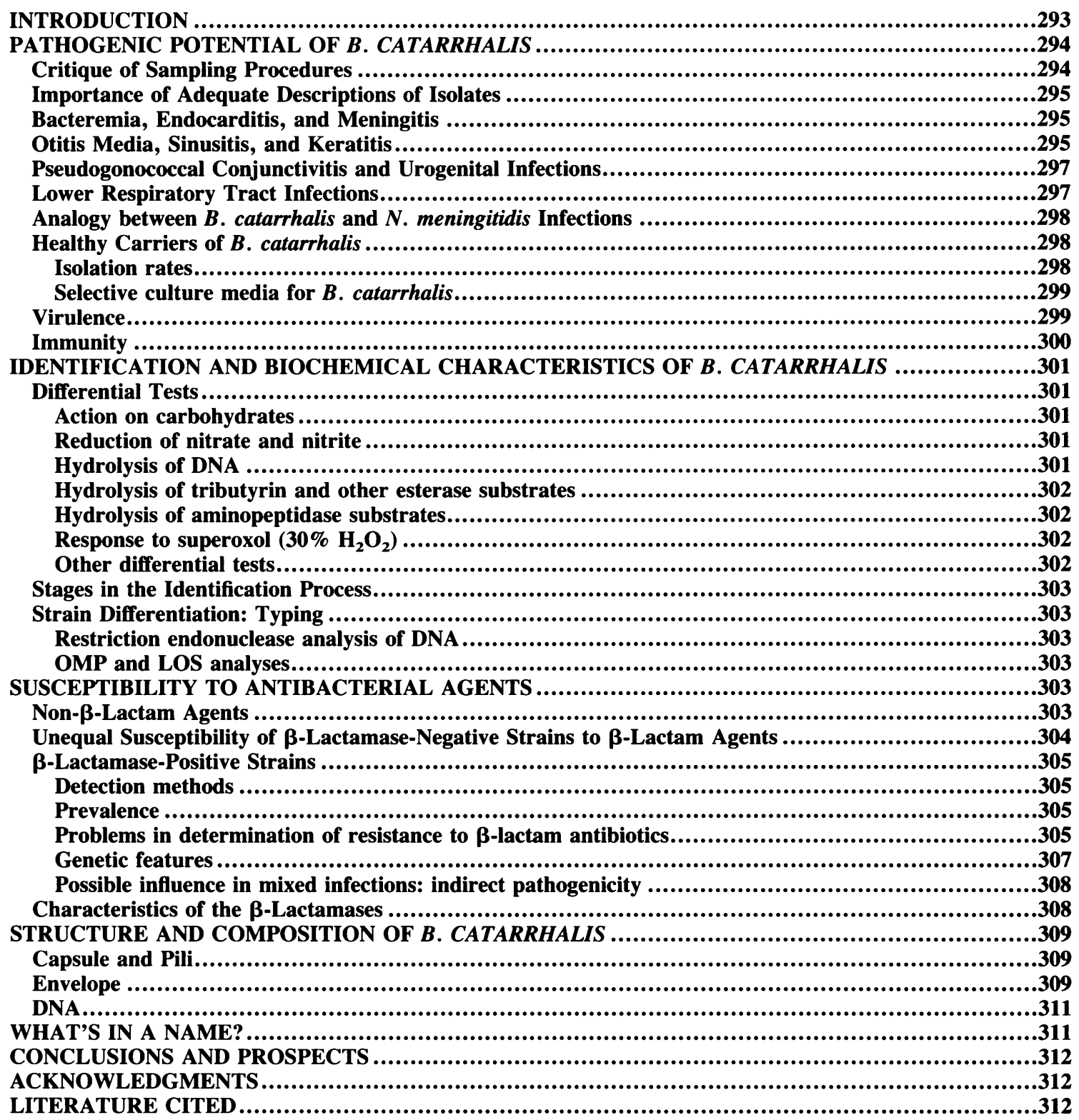

\section{INTRODUCTION}

Branhamella catarrhalis received little respectful attention until recently. Strains isolated from clinical material were often disregarded because of the repeated, confident assertion that the organism is nonpathogenic and commonly

$\dagger$ Present address: 3550 Lebon Drive, no. 6420, San Diego, CA 92122. present in the normal pharynx $(117,209,232,316)$. Consequently, medical technologists usually elected not to identify organisms referred to as nongonococcal, nonmeningococcal neisseriae or normal flora $(58,221,248,262,268)$. In a discussion during a symposium on $B$. catarrhalis held in 1985, C. D. Bluestone [Drugs 31(Suppl. 3):38, 1986] stated his impression that, in non-university hospitals in the United States, "the organism is still frequently called Neisseria catarrhalis and is not considered pathogenic." On the other 
TABLE 1. Chronology of differential biochemical tests developed for Neisseria spp. and B. catarrhalis

\begin{tabular}{lll}
\hline \multicolumn{1}{c}{ Test } & Date & \multicolumn{1}{c}{ Authors (reference) } \\
\hline Acid production from carbohydrates in & & \\
Rich basal medium & 1905 & Dunn and Gordon (108) \\
Low-concn peptone medium & 1983 & Knapp and Holmes (178) \\
Buffered salts solution & 1970 & Catlin (61) \\
Polysaccharide synthesis from sucrose & 1948 & Hehre and Hamilton (142) \\
Nitrate and nitrite reduction & 1961 & Berger (20) \\
& 1959 & Véron et al. (308) \\
Butyrate esterase action on & 1961 & Berger (22) \\
Tributyrin & & \\
Reduced opacity in agar & 1962 & \\
Acid production in fluid & 1981 & Berger and Paepcke (25); Pike et al. (236) \\
4-Methylumbelliferyl butyrate & 1988 & Riou et al. (254) \\
Indoxyl butyrate & 1989 & Vaneechoutte et al. (301) \\
Deoxyribonucleate hydrolysis & 1964 & Dealler et al. (88) \\
& 1977 & Catlin and Cunningham (69) \\
$\gamma$-Glutamyl- $\beta-$ naphthylamide hydrolysis & 1967 & Riou and Guibourdenche (256) \\
& 1978 & Mannheim and Bürger (199) \\
o-Nitrophenyl- $\beta-\mathrm{D}-$ galactopyranoside hydrolysis & 1968 & D'Amato et al. (84) \\
Superoxol (30\% $\mathrm{H}_{2} \mathrm{O}_{2}$ ) decomposition & 1982 & Corbett and Catlin (80) \\
\hline
\end{tabular}

hand, a developing appreciation of the pathogenic potential of $B$. catarrhalis and concern over the increasing prevalence of $\beta$-lactamase-producing $\left(\beta \mathrm{la}^{+}\right)$strains in clinically significant infections are reflected in numerous recent reports. These are summarized in several valuable reviews (e.g., see references 140, 158, 305, and 321). The 1989 symposium, "Branhamella catarrhalis: a Microbiological and Clinical Update," illustrates the rising interest in this organism.

Originally described in German as Mikrokokkus catarrhalis by R. Pfeiffer (cited by Frosch and Kolle [125]) and then in English as Micrococcus catarrhalis (e.g., see reference 108), the species was subsequently classified in the genus Neisseria $(26,41,149)$. In 1970 , it was transferred to the new genus Branhamella (60), named for Sara E. Branham. Her studies (described in a biographical sketch by Pittman [239]) greatly contributed to knowledge of the neisseriae. $B$. $c a$ tarrhalis was accepted in the 1974 edition of Bergey's Manual (245), but was reduced to a subgenus within the genus Moraxella in the 1984 edition of Bergey's Manual (37). My reasons for retaining the name Branhamella catarrhalis will be discussed in a later section. In describing the numerous studies of this organism, however, I shall use the name that was given to the bacteria in each report.

$B$. catarrhalis has been regarded as one of the commonest inhabitants of the pharynx (195). A current textbook (324) estimates its presence as $12 \%$ in the nose and nasopharynx and 10 to $97 \%$ in the oropharynx. Early studies had found "Micrococcus catarrhalis" in 33\% of nasal cultures (9), $18 \%$ of nasopharyngeal cultures (112), and $46 \%$ of nose and throat cultures from healthy persons and $45 \%$ of subjects with the common cold (130). "M. catarrhalis" was recognized as a gram-negative diplococcus, capable of growth at $22^{\circ} \mathrm{C}$, which displays certain well-described colony characteristics and has no action on "fermentable substances" $(9,108,112)$.

Significant advances in our understanding of $B$. catarrhalis awaited the development of additional tests (Table 1). These enabled Berger $(23,25)$ to show that the common, nonsaccharolytic, gram-negative cocci comprised two distinct species, Neisseria cinerea and " $N$. catarrhalis." Described in German and later in French (256), $N$. cinerea usually was overlooked until 1984, when it was further characterized by Knapp et al. (180). Two studies of bacteria isolated from throat cultures on semiselective media showed that the ratios of $N$. cinerea/B. catarrhalis were $26: 1$ (23) and $6: 1$ (179). Accurate species identification together with the application of methods for typing strains and determining their virulence are needed in further studies of carrier and case isolates.

The intent of this review is to provide a critical evaluation of $B$. catarrhalis and its relation to disease, susceptibility to antibiotics, basic biological and differential features, and areas of fundamental research in need of further investigation.

\section{PATHOGENIC POTENTIAL OF B. CATARRHALIS}

Virulence is not an exclusive characteristic of the bacterium, but involves bacterium-host interactions. The process of infection starts with bacterial attachment to mucosal cells and may proceed through several distinguishable steps, possibly ending in dissemination $(204,285)$. The outcome depends on numerous variables, such as the number and characteristics of bacteria and nonspecific and specific immune defenses. Immunodeficiency states and certain chronic debilitating diseases are predisposing factors. My evaluation of the pathogenic potential of $B$. catarrhalis considers the methods used for collecting and processing specimens and bacterial identification as well as clinical observations.

\section{Critique of Sampling Procedures}

The early view that $B$. catarrhalis has no significance in bronchopulmonary infections is due in part to a failure to appreciate that expectorated sputum is contaminated with indigenous pharyngeal bacteria. Transtracheal puncture was introduced as a procedure for collecting uncontaminated material from the lower respiratory tract $(127,158,224,270)$, but it causes patient discomfort. Therefore, Geckler et al. (127) and Aitken and Thornley (5) compared transtracheal aspirates with good-quality sputum specimens plated quantitatively and found good agreement between the results. It is essential to prepare and Gram stain a smear of the expectorated sputum and observe the numbers of host cells and bacteria. Good-quality specimens contain at least 25 leukocytes and no more than 10 squamous epithelial cells per 
low-power $(\times 100$ magnification) field (269). The presence of more than 25 squamous epithelial cells indicates that a specimen is unsatisfactory since these cells are derived from oropharyngeal mucous membranes $(73,127,241)$. The sputum is liquefied with buffered $N$-acetyl-L-cysteine $(28,211)$, dithiothreitol (5), or Sputasol (Oxoid Ltd., London, England) $(200,279)$ and mixed to permit a uniform sampling. For research purposes, many workers then prepare serial dilutions for plating on agar medium since they attach etiological significance to $B$. catarrhalis when its numbers of CFU are $>10^{7} / \mathrm{ml}(28,93,211,218,267)$ or $10^{8} / \mathrm{ml}(5,200$, 277).

Middle-ear fluid (MEF) obtained by tympanocentesis has been the preferred specimen for research on otitis media because the tympanic cavity is normally sterile, but this invasive procedure is not done routinely in pediatric practice (272, 274). Appropriate nasopharyngeal cultures (but not throat cultures) in which $B$. catarrhalis constitutes the majority of colonies were considered by Kamme et al. (168) and Schwartz et al. (272) to be of some help in predicting the middle-ear pathogen in acute otitis media. For maxillary sinus infections, on the other hand, the results of nasopharyngeal cultures from children (309) or nasal cultures from adults $(46,163)$ were of little predictive value; the reliability compared with sinus aspirates was $20 \%$ for $B$. catarrhalis (163).

\section{Importance of Adequate Descriptions of Isolates}

Chapters in the 1974 editions of three widely used manuals $(62,82,245)$ for the first time listed nitrate reduction as a characteristic of $B$. catarrhalis. This test and others developed more recently are needed to differentiate $B$. catarrhalis from other species of gram-negative cocci, such as $N$. cinerea, that do not form acid from carbohydrates.

The characteristics of the isolates from the first five cases of systemic disease listed in Table 2 were compatible with " $N$. catarrhalis" as it was known, but did not include nitrate reduction. For these strains and for others reported in later papers that did not specify the differential tests performed, or at least cite a pertinent reference, I have noted that a particular characteristic was not stated. Such strains are referred to in this review as presumptively identified $B$. catarrhalis since the descriptions were insufficient to establish that the identifications satisfy the criteria currently accepted for determining the species.

This critical approach probably underestimates the percentage of strains adequately characterized in the laboratory, but focuses attention on the necessity that published reports provide sufficient detail to confirm the identification.

\section{Bacteremia, Endocarditis, and Meningitis}

At least 21 cases of meningitis (cited in references 77,113 , 126, and 287) and 1 case of endocarditis (76) which occurred before 1965 were caused by nonsaccharolytic, gram-negative diplococci resembling " $N$. catarrhalis." Confirmed $B$. catarrhalis strains were isolated from patients with bacteremia $(13,50,72,98,140,197,218,268)$ and endocarditis $(300)$, and presumptively identified strains were recovered from other patients with systemic disease (Table 2). Six of the isolates were said to be penicillin resistant $(13,242,268)$ and seven produced $\beta$-lactamase $(11,72,75,98,138,140,306)$. Identical characteristics of the isolates from two or more relevant specimens established their role in the diseases afflicting at least 17 of these patients. Suppurative arthritis in a 3-month- old girl which affected two joints, knee and hip, was caused by a penicillin-susceptible strain (confirmed by nitrate reduction and DNase production) (151); dissemination of the bacteria through the bloodstream probably occurred, although a blood culture was sterile. Similarly, a hematogenous route of infection was presumed for a case of acute purulent pericarditis in a 65-year-old man (183). A case of $B$. catarrhalis septicemia with disseminated intravascular coagulation leading to death in 1983 was cited by McLeod et al. (205).

Petechial rash, ecchymoses, or purpura fulminans (indicated by $P$ in Table 2), occurred in nine children. These cutaneous manifestations are characteristic of meningococcal septicemia (illustrated in Youmans et al. [324]). Two children with $B$. catarrhalis bacteremia, including one who developed purpura, did not appear to be seriously ill and their bacteremia was unsuspected (13).

Immunodeficiency/suppression or neutropenia was conductive to many of these infections $(11,31,50,52,72,75,98$, 144, 268). Septicemia in an infant with acquired immunodeficiency syndrome was caused by $\boldsymbol{B}$. catarrhalis (presumptive identification) (320). Other predisposing conditions mentioned were neurosurgery (113), gynecological surgery (105), inguinal hernia surgery (218), otolaryngological surgery (219), aortic prosthesis and dental extractions (242), hemodialysis $(300)$, chronic obstructive pulmonary disease $(140$, 287), and mouth-to-mouth resuscitation and type $A$ influenza (306). No predisposing condition was evident in seven children $(13,31,75,77,118,232)$ or two adults $(138,197)$.

\section{Otitis Media, Sinusitis, and Keratitis}

"Neisseria sp."' (not identified) was considered a sufficient identification of strains isolated from MEF from 15 children in a study published in 1979 (272) and from 18 children in a 1982 report (129). By 1985, however, a textbook (324) could state that $B$. catarrhalis is "convincingly associated" with acute suppurative otitis media and sinusitis.

Evidence for this comes from bacteriological studies of MEF obtained by needle aspiration through the tympanic membrane. Many cultures yielded " $N$. catarrhalis" (78, $135,141,166,168)$ and $B$. catarrhalis $(30,184,188,189,194$, $265,274,290,305,310)$. The organism also was isolated from aspirates obtained by puncture of the maxillary sinus $(30,46$, $163,225,309$ ).

The identity of $B$. catarrhalis was confirmed by nitrate reduction or DNase production by the strains reported in eight of the foregoing studies $(46,163,166,168,188,225$, $274,305)$, but the other identifications were presumptive. The middle ear and sinuses normally are sterile. Cultures of the external auditory canal did not contain $B$. catarrhalis $(141,166,168,184,274)$, thereby excluding this site as a likely source of MEF specimen contamination (189). External auditory canal cultures from 4 of 72 children were reported as "Neisseria sp." (43); these isolates which had not been identified further were erroneously listed as $B$. catarrhalis in a later review (44).

Additional evidence of the pathogenic role of $B$. catarrhalis in many of these infections was the observation of gram-negative diplococci occurring intracellularly in polymorphonuclear leukocytes in MEF. Also, immunoglobulin A (IgA) class antibodies specific for $B$. catarrhalis were detected in MEF and in sera from some children with otitis media (189).

Otitis media is the most frequent diagnosis made by physicians who provide health care for children $(30,274)$. 
TABLE 2. B. catarrhalis strains (presumptive or confirmed) isolated from patients with systemic disease

\begin{tabular}{|c|c|c|c|c|c|c|c|c|c|c|}
\hline \multirow[b]{2}{*}{$\mathrm{Yr}^{a}$} & \multirow[b]{2}{*}{$\begin{array}{l}\text { Ref- } \\
\text { erence }\end{array}$} & \multicolumn{2}{|l|}{ Patients } & \multirow[b]{2}{*}{ Features of infection ${ }^{b}$} & \multirow[b]{2}{*}{$\begin{array}{l}\text { Positive specimen } \\
\text { (no. })^{c}\end{array}$} & \multicolumn{5}{|c|}{ Characteristics $^{d}$} \\
\hline & & Age & No. & & & $\begin{array}{l}\text { GN } \\
\text { diplo- } \\
\text { cocci }\end{array}$ & $\begin{array}{l}\text { Oxidase } \\
\text { positive }\end{array}$ & $\begin{array}{l}\text { Nonsac- } \\
\text { charo- } \\
\text { lytic }\end{array}$ & $\begin{array}{c}\mathrm{NO}_{3} \\
\text { reduction } \\
\text { to nitrite }\end{array}$ & $\begin{array}{c}\text { DNase } \\
\text { pro- } \\
\text { duced }\end{array}$ \\
\hline 1965 & 232 & $2.5 \mathrm{yr}$ & 1 & Bacteremia, meningitis, $\mathrm{P}$ & Blood, CSF, throat & Yes & Yes & Yes & NS & NS \\
\hline 1967 & 77 & $14 \mathrm{mo}$ & 1 & Meningitis, $\mathrm{P}$ & CSF, throat & Yes & Yes & Yes & NS & NS \\
\hline 1969 & 118 & $6 \mathrm{mo}$ & 1 & Septicemia, meningitis, $\mathrm{P}$ & $\begin{array}{l}\text { Blood, CSF, bone } \\
\text { marrow }\end{array}$ & Yes & Yes & Yes & NS & NS \\
\hline 1970 & 113 & $36 \mathrm{yr}$ & 1 & Meningitis, purulent rhinorrhea & CSF, nasal pus & Yes & Yes & Yes & NS & NS \\
\hline 1974 & 52 & $8 \mathrm{yr}$ & 1 & Septicemia, polyarthropathy, $\mathrm{P}$ & Blood, skin lesion & Yes & Yes & Yes & NS & NS \\
\hline 1976 & 242 & $69 \mathrm{yr}$ & 1 & Endocarditis & Blood (7) & NS & NS & NS & NS & NS \\
\hline 1976 & 105 & $45 \mathrm{yr}$ & 1 & Endocarditis & Blood (6) & NS & NS & NS & NS & NS \\
\hline 1980 & 218 & $11 \mathrm{yr}$ & 1 & Pneumonia & Blood & Yes & Yes & Yes & Yes & NS \\
\hline 1980 & 98 & $19 \mathrm{mo}$ & 1 & Bacteremia, $\mathbf{P}$ & Blood (6) & Yes & Yes & Yes & Yes & NS \\
\hline 1980 & 287 & $64 \mathrm{yr}$ & 1 & Bacteremic pneumonia & Blood (2), ETS & Yes & NS & NS & NS & NS \\
\hline 1983 & 50 & $3 \mathrm{yr}$ & 1 & Septicemia, $\mathrm{P}$ & Blood, CSF, PF, lunge & NS & NS & Yes & Yes & Yes \\
\hline 1983 & 197 & $19 \mathrm{yr}$ & 1 & Bacteremic pneumonia & Blood & Yes & Yes & Yes & Yes & NS \\
\hline 1983 & 11 & $3.5-4 \mathrm{yr}$ & 3 & Bacteremia & Blood & NS & NS & NS & NS & NS \\
\hline 1983 & 144 & $24 \mathrm{yr}$ & 1 & $\begin{array}{l}\text { Septicemia, sinusitis, subcuta- } \\
\text { neous nodules }\end{array}$ & Blood (3) & NS & NS & NS & NS & NS \\
\hline $1976-1985^{f}$ & 268 & $31 \mathrm{mo}$ & 1 & Septicemia, $\mathrm{P}$ & Blood & Yes & Yes & Yes & Yes & NS \\
\hline $1976-1985^{f}$ & 268 & $15,39,41 \mathrm{yr}$ & 3 & Septicemia & Blood & Yes & Yes & Yes & Yes & NS \\
\hline 1985 & 300 & $62 \mathrm{yr}$ & 1 & Endocarditis & Blood (2) & Yes & Yes & Yes & Yes & Yes \\
\hline 1985 & 13 & $11 \mathrm{mo}$ & 1 & $\begin{array}{l}\text { Bacteremia, tonsillar exudate, } \\
\mathrm{P}\end{array}$ & Blood & Yes & Yes & Yes & Yes & Yes \\
\hline 1985 & 13 & $4 \mathrm{yr}$ & 1 & Bacteremia, sinusitis & Blood & Yes & Yes & Yes & Yes & Yes \\
\hline 1985 & 72 & $69 \mathrm{yr}$ & 1 & Bacteremia & Blood & Yes & Yes & Yes & Yes & $\mathrm{NS}^{g}$ \\
\hline 1985 & 306 & $2.5 \mathrm{mo}$ & 1 & Bacteremia & Blood & NS & NS & NS & NS & NS \\
\hline 1987 & 140 & $69 \mathrm{yr}$ & 1 & Bacteremic pneumonia & Blood, ETS & Yes & Yes & Yes & Yes & Yes \\
\hline $1977-1988^{f}$ & 31 & $1-36 \mathrm{mo}$ & 5 & Bacteremia & Blood & NS & NS & NS & NS & NS \\
\hline 1988 & 138 & $40 \mathrm{yr}$ & 1 & Septicemia & Blood (3) & NS & NS & NS & NS & NS \\
\hline 1988 & 219 & $5 \mathrm{yr}$ & 1 & Bacteremia, meningitis & Blood, CSF & Yes & NS & NS & NS & NS \\
\hline 1989 & 75 & $4 \mathrm{yr}$ & 1 & Pneumonia, otitis media, $\mathrm{P}$ & Blood & NS & NS & NS & NS & NS \\
\hline 1989 & 75 & $7 \mathrm{yr}$ & 1 & Tracheitis, bacteremia & Blood, ETS & NS & NS & NS & NS & NS \\
\hline
\end{tabular}

${ }^{a}$ Date of isolation given in text or estimated from the date manuscript was submitted or published.

$b \mathrm{P}$, Petechiae and/or purpura or ecchymoses.

c Number of blood cultures yielding bacterial growth is given in parentheses. CSF, Cerebrospinal fluid; ETS, endotracheal secretion; PF, pleural fluid.

${ }^{d} \mathrm{GN}$ diplococci, Gram-negative diplococci observed; NS, not stated.

e Specimens from all sites yielded mixed cultures of $B$. catarrhalis, the predominant organism, and $\boldsymbol{H}$. influenzae.

$f$ Patient(s) identified by reviewing records for the period indicated.

$g$ Tributyrin hydrolysis was positive (a test substituted for DNase production).

Middle-ear infections are usually caused by microorganisms that originate in the nasopharynx, traverse the Eustachian tube, and invade the tympanic cavity. Recent studies of isolates from MEF show that $B$. catarrhalis is the third most common species, behind Streptococcus pneumoniae and Haemophilus influenzae $(30,189,194,265,305,310)$.

In 1967, Coffey et al. (78) emphasized that " $N$. catarrhalis" shares with pneumococci and $H$. influenzae the ability to invade the tympanic cavity. This insight was based on finding pure cultures in MEF from $49(7 \%)$ of 698 children (mean age, 1 year 10 months) studied during a 2-year period ending in June 1966. Mixed cultures were isolated in three other cases. The otitis media was bilateral in $35 \%$ of the 49 children. Smears of $23(47 \%)$ of the MEF specimens revealed gram-negative diplococci, either extracellular or intracellular in polymorphs. Recent observations indicate that the size of the population in MEF exceeds $10^{4} \mathrm{CFU} / \mathrm{ml}$ when bacteria can be seen in a smear (310). Stenfors and Räisänen (290) developed a method of quantitative microscopy and demonstrated that the bacterial content was $2.6 \times 10^{7} / \mathrm{ml}$ (median value) in MEF characterized as mucopurulent, but only 2.0 $\times 10^{5} / \mathrm{ml}$ in "sticky glue"-type effusion.

Prior to 1980 the reported frequency of $B$. catarrhalis in cultures of MEF obtained from children with acute otitis media was $<10 \%(78,135,166,168,189,274,305)$. Unac- countably, a sharp increase in the percentage was found in a study conducted by Shurin et al. (274) in Cleveland, Ohio, between October 1980 and February 1982. Strains, confirmed by nitrate reduction and DNase activity, were isolated in pure culture from MEF obtained from $20(20 \%)$ of 98 children. In a 2-year extension of this study (305), $B$. catarrhalis was identified in MEF from $15 \%$ of children with otitis media and was more common in fall and winter (20\%) than in spring and summer $(11 \% ; P<0.05)$. The frequencies of the organism in positive MEF cultures examined in other American studies after 1981 were $14 \%$ (310), 16\% (30), and $19 \%$ (184).

On the other hand, in a Finnish study of acute otitis media, Ruuskanen et al. (265) presumptively identified $B$. catarrhalis in $7 \%$ of 3,332 MEF cultures examined over a 6-year period, 1980 to 1985 . This was $12.5 \%$ of all MEF cultures that showed bacterial growth. Coexisting viral infection, especially with respiratory syncytial virus, was detected in children with otitis media (265). A Swedish study of acute otitis media revealed pure cultures of $B$. catarrhalis in $9 \%$ of MEF cultures from 75 children; $43 \%$ of the accompanying nasopharyngeal specimens from these children contained presumptive $B$. catarrhalis (194).

The cause of keratitis reported in 11 patients since 1980 was attributed to B. catarrhalis (196). 


\section{Pseudogonococcal Conjunctivitis and Urogenital Infections}

A case of conjunctivitis in a 5-day-old girl was described in 1987 by Romberger et al. (260). A strain isolated from the purulent eye discharge was reported as $N$. gonorrhoeae resistant to penicillin. The diagnosis of gonorrhea was reported to the public health department and the parents were subjected to intramuscular injections of cefotaxime. This strain subsequently was identified as $\boldsymbol{B}$. catarrhalis by a state laboratory and the Centers for Disease Control in Atlanta, $\mathrm{Ga}$. The stressful implications of the erroneous identification can be imagined.

Historically, ophthalmia neonatorum was attributed to $N$. gonorrhoeae, but the identification often was based solely on the characteristics of bacteria seen in Gram-stained preparations of conjunctival exudate $(248,284,297)$. B . catarrhalis (confirmed by nitrate reduction) as a cause of ophthalmia neonatorum was first reported by Spark et al. (284) in 1979 in an infant with fever of 3-week duration and a conjunctivitis that was partially suppressed by short-term parenteral antibiotic therapy. Righter and Nicol (248) described another case of conjunctivitis in an infant who received only ineffective topical therapy for months because cultures of purulent discharge from both eyes were reported as growing normal flora, not $N$. gonorrhoeae or $N$. meningitidis. Thirteen additional cases of conjunctivitis in infants were reportedly caused by $B$. catarrhalis (cited in references 260,297 , and 317). Furthermore, a confirmed strain was isolated from conjunctival discharge obtained from a previously healthy, 58-year-old woman with acute bilateral conjunctivitis (172).

Confirmed $B$. catarrhalis strains were isolated from urethral exudates from four men with urethritis $(96,278)$ and from urine specimens collected 5 days apart from a woman with chronic pyelonephritis (153). The organism was the only pathogen isolated from a urinary tract infection in a 13-year-old girl (2). Strains provisionally identified as " $N$. catarrhalis" were recovered from four anal canal specimens cultured on selective medium (29). Johnson (158) cited additional cases of urogenital infections associated with " $N$. catarrhalis" and pointed out that their pathogenic role remained speculative because of the possibility of infection with Chlamydia trachomatis or Ureaplasma urealyticum that would not have been detected by conventional bacteriology.

\section{Lower Respiratory Tract Infections}

Pneumonia, acute exacerbations of chronic bronchitis, tracheitis, and empyema are caused by $B$. catarrhalis. The isolates were regarded as primarily opportunistic in many cases. The factors predisposing to infection include underlying disease of the bronchial tree or lung parenchyma, especially chronic obstructive pulmonary disease, and an immunodeficiency state due to chemotherapeutic agents or abnormalities involving the cellular or humoral immune systems $(58,134,140,277)$. Thus, $B$. catarrhalis pneumonia was reported in patients with multiple myeloma $(91,209)$, chronic lymphocytic leukemia (287), or quantitative abnormalities of serum immunoglobulins $(171,192)$. Advanced age appears to be a factor, possibly due to the significant reductions of IgG and IgM seen after age 60 years (51). Viral damage to respiratory tract epithelium, for example, by respiratory syncytial virus infection $(6,319)$, may promote invasion by $B$. catarrhalis. A high risk of aspiration from the oropharynx has been identified as a predisposing factor in some patients $(259,277)$.
B. catarrhalis pneumonia may present a clinical picture similar to other bacterial pneumonias, but generally is a milder illness except in the immunocompromised patient (321). An indication of its relative mildness is found in reports that most blood cultures are negative $(58,85,118$, 209, 221, 241, 259, 313).

The earlier reluctance to accept a pathogenic role for $B$. catarrhalis has diminished in view of evidence of its presence in pure cultures in sites that normally are sterile. Thus, it has been isolated from pericardiocentesis fluid aspirated from a patient with acute pericarditis (183). Pleural effusion specimens obtained by thoracentesis from each of two patients with empyema yielded $B$. catarrhalis on two occasions $(83,313)$. The organism was isolated from transtracheal or endotracheal aspirates from 47 patients with pneumonia or acute bronchopulmonary infections $(5,73,99,171$, $173,192,209,224,270,279,287,316)$. Sections of lung tissue from two patients who died with untreated pneumonia revealed intracellular and extracellular gram-negative diplococci $(209,277)$, and $B$. catarrhalis was isolated in pure culture from postmortem lung secretions (277). Furthermore, elevated antibody titers were detected in convalescent sera from patients with $B$. catarrhalis bronchopulmonary infections $(28,71,197)$.

A sputum culture usually yields clinically significant results if the specimen is of good quality and is inoculated by using quantitative methods (described above). Nevertheless, mixed cultures of $B$. catarrhalis with $H$. influenzae or pneumococci or both are isolated from substantial numbers of sputum specimens $(73,200,241,277)$. Some authors questioned the role of $B$. catarrhalis as a respiratory pathogen in cases of mixed infection with acknowledged pathogens $(134,259)$. Others omitted such cases from consideration $(207,279)$. As expected, sputa from patients with aspiration pneumonia often yielded mixed cultures typical of oropharyngeal flora (259).

Seeking further evidence of the clinical significance of $B$. catarrhalis in bronchopulmonary infection, Yuen et al. (328) conducted a case control study of 26 patients ("cases") whose expectorated sputum yielded pure cultures of confirmed B. catarrhalis and patients ("controls") whose sputum cultures contained only commensal Neisseria spp. (DNase negative). Proportionately more cases than controls $(P<0.05)$ showed three or more clinical features of bronchopulmonary infection (cough with increased purulence of the sputum, fever of $>37.4^{\circ} \mathrm{C}$, leukocytosis, chest X-ray signs, and crepitations and/or dullness of the chest). Furthermore, intracellular gram-negative diplococci were observed in 13 of the 26 sputum specimens containing $B$. catarrhalis and none were detected in the control sputa.

Lower respiratory tract infections caused by $B$. catarrhalis in children tend to differ from those in adults by the absence of underlying respiratory disease (200). Thus, $B$. catarrhalis bronchopneumonia developed in three children who were intubated and on mechanical ventilation following elective surgery or trauma (173) and also was reported in a 15-day-old, prematurely born infant whose lungs had appeared normal 5 days earlier (228). On the other hand, preexisting lung disease was recognized in five children, 6 weeks to 6 months of age, who suffered from $B$. catarrhalis pneumonia. All had been born prematurely, entered a hospital in Phoenix, Ariz., during winter months, and experienced precipitous clinical deterioration requiring emergency intubation and mechanical ventilation (19).

Tracheitis caused by $B$. catarrhalis developed in a previously healthy 11-month-old girl (137) and also in a 4-year-old 
girl following local injury to the trachea by a cuffed endotracheal tube (114). Epithelial damage by respiratory syncytial virus infection was considered a predisposing factor in the development of $\boldsymbol{B}$. catarrhalis tracheitis in a 9-year-old boy (319) and a 6-month-old boy (6).

A nonhealing, thoracic, surgical wound infection was described by Gray et al. (132) in a 59-year-old woman who had undergone an open lung biopsy procedure. B. catarrhalis was isolated from deep thoracotomy wound specimens as well as from tracheal secretions and sputum, and smears of each revealed numerous polymorphonuclear leukocytes and intracellular and extracellular gram-negative diplococci.

The peak incidence of $B$. catarrhalis respiratory infections occurs in winter months. This was found south of the equator in Western Australia (93) and New Zealand (279), as well as in Denmark (269), The Netherlands $(85,86)$, England (200), Scotland (57), Japan (203), and the United States (241).

Davies and Maesen (86) described a remarkable 10-year study at the Regional Public Health Laboratory in Heerlen, The Netherlands. Approximately 1,700 positive cultures from respiratory tract specimens were obtained per year. The frequency of $B$. catarrhalis strains, which in 1977 was $5 \%$, steadily increased until in 1982 it reached $20 \%$ and by 1986 it accounted for $26 \%$ of the respiratory tract pathogens. This inexplicable rise occurred in a relatively constant antibiotic climate and was not merely the result of increased awareness in the laboratory.

Person-to-person transmission of $B$. catarrhalis was thought responsible for some hospital-acquired infections. Pulmonary infections in three premature infants were traced to an attending nurse (139). Acute bronchitis caused by a $\mathrm{Bla}^{+}$strain developed in a previously healthy, 22-year-old nurse who worked in a chest ward (207). Calder et al. (57) undertook an environmental study of chest wards in which clusters of cases were found adjacent to index patients. Nasopharyngeal carriage of $\boldsymbol{B}$. catarrhalis was identified in $7 \%$ of staff members and $8 \%$ of patients. Six B. catarrhalis cultures were isolated from 117 settle plates that were exposed for 6 to $8 \mathrm{~h}$ in a duty room frequented by carriers and in a chest ward. Also, experiments showed that the organism survived for at least 3 weeks in sputum (57). This circumstantial evidence of environmental spread illustrated the need for a means of determining strain relatedness.

The development of restriction endonuclease typing (See subsection, "Strain Differentiation") made it possible to trace the source of an outbreak of respiratory illness due to $\mathrm{Bla}^{+} B$. catarrhalis that occurred in an intermediate care unit. Patterson et al. (230) analyzed isolates from three staff members and ten patients, four with pneumonia, four with bronchitis, and two who were asymptomatic (hospitalized for nonrespiratory conditions). The typing results indicated that the isolates from five patients (including one asymptomatic) and two staff probably had a common origin.

\section{Analogy between $B$. catarrhalis and $N$. meningitidis Infections}

B. catarrhalis resembles $N$. meningitidis in many respects in spite of their very significant genotypic differences. Their natural habitat is believed to be human beings exclusively, and the nasopharynx is the site of initial mucosal colonization $(37,145,204,212,307)$. Presumably this is due to the distribution of specific host cell receptors (16). Both organisms often are carried asymptomatically $(212,292)$. The carriage rates are lower than formerly believed, however, owing to the recognition of distinctions between $B$. catarrhalis and $N$. cinerea and the differentiation of nontypable meningococci from $N$. lactamica and $N$. polysaccharea $(177,258) . N$. meningitidis may be more pathogenic and less dependent than $B$. catarrhalis on predisposing conditions for the manifestation of disease. Nevertheless, both possess capsules and endotoxin which may facilitate later stages of infection.

Systemic infections with both organisms may be accompanied by petechial rashes, purpura, or ecchymoses. Such lesions were found in nine patients (Table 2), all of whom were $\leq 8$ years of age, and in a 64-year-old man with pneumonia from whom $B$. catarrhalis was isolated in pure culture from a transtracheal aspirate (316). Disease caused by either organism may display a rapid onset of symptoms $(118,205)$ or be the cause of an unsuspected bacteremia in young children who present with fever and upper respiratory infections (13).

An unknown number of infections with $B$. catarrhalis have been attributed to $N$. meningitidis $(52,72,77,192,205$, 232). This error would result from the failure to use adequate differential tests because of the belief that gram-negative diplococci seen in purulent spinal fluid or good-quality sputum must be the established pathogen.

The term commensal, which refers to the nondetrimental coexistence of organisms, has frequently been applied to $B$. catarrhalis but not to $N$. meningitidis. Characterizing one organism as a commensal $(205,324)$ or a nonpathogen $(117)$ and another as a pathogen carries unwarranted implications of qualitative differences. Actually, the distinction between their potential pathogenicity appears to be primarily quantitative.

\section{Healthy Carriers of $\boldsymbol{B}$. catarrhalis}

Isolation rates. Various culture media containing selective agents, together with differential tests sufficient to confirm the identity of $B$. catarrhalis, were used in investigations of carrier rates (Table 3). Also, in two of these studies the prevalence of $N$. cinerea was determined as $14.5 \%$ (23) and $28.2 \%$ (177) compared with $<5 \%$ for $B$. catarrhalis. Nasopharyngeal colonization of healthy children in Cleveland, Ohio, was $46 \%$ in fall and winter, but only $9 \%(P<0.005)$ in spring and summer, overall $18 \%(305)$. Higher percentages of $B$. catarrhalis were isolated from children younger than 24 months than from older children (Table 3).

A corresponding age relationship was observed by Arkwright (9) in 1907. "Micrococcus catarrhalis" was isolated "from a much larger proportion of infants under one year than of older children or of adults: the last furnished proportionately the fewest strains" (9). Further evidence came from three studies in the 1980 s of nasopharyngeal specimens taken in fall or winter months from Swedish children who showed no symptoms of respiratory infections. B. catarrhalis was isolated from $45 \%$ of children 2 years or younger, but from only $17 \%$ aged 6 to 7 years (194) and, similarly, from $36 \%$ of children 2 years or younger, but from only $13 \%$ who were 6 to 9 years old (48). Mölstad et al. (210) studied 191 children aged 1 to 7 (mean, 4.5) years who attended day-care nurseries and isolated $B$. catarrhalis from $58 \%$. Selective media were not used in these investigations, and some of the strains possibly were $N$. cinerea since not all identifications were confirmed. In contrast to results with children, B. catarrhalis was recovered from only $3 \%$ of blood agar cultures of posterior nasal specimens from 286 healthy men (mean age, 20 years) who were military service recruits in Finland (163). 
TABLE 3. Isolation of confirmed $B$. catarrhalis strains on semiselective and selective media

\begin{tabular}{|c|c|c|c|c|c|}
\hline Author(s) & $\mathrm{Yr}$ & Place & Subjects (no. in study) & Culture site & B. catarrhalis (\%) \\
\hline Berger (21) & 1961 & Hamburg & Adults (172) & Throat $^{a}$ & 0.6 \\
\hline Knapp (177) & $1982-1983$ & Seattle & Adults (202) & Oropharynx ${ }^{b}$ & 4.5 \\
\hline Calder et al. (57) & 1984 & Edinburgh & Adults $(148)^{\mathrm{c}}$ & Nasopharynx & 7.4 \\
\hline DiGiovanni et al. (93) & 1985 & Perth $^{d}$ & Adults (123) & Nasopharynx & 2.4 \\
\hline \multirow[t]{2}{*}{ Van Hare et al. (305) } & $1982-1983$ & Cleveland & Children $<24$ mo (37) & Nasopharynx & 24.0 \\
\hline & & & Children $\geq 24$ mo (14) & Nasopharynx & 0 \\
\hline \multirow[t]{2}{*}{ Vaneechoutte et al. (302) } & 1988 & Ghent & Children $3-12$ yr (178) & Saliva & 48.9 \\
\hline & & & Children 3-12 yr (75) & Throat & 30.7 \\
\hline
\end{tabular}

"Carriage of " $N$. catarrhalis" was reported by Berger (21) as $15 \%$ ( 26 of 172 subjects); however, after $N$. cinerea was defined in a later study (25), retests of the 26 strains identified $25(14.5 \%)$ as $N$. cinerea and $1(0.6 \%)$ as " $N$. catarrhalis" (23).

${ }^{b} N$. cinerea was identified in $28.2 \%$ of the cultures.

c Hospital staff and patients whose illness was not attributed to $B$. catarrhalis infection. All other study groups were made up of subjects without respiratory symptoms.

${ }^{d}$ Western Australia.

Selective culture media for $\boldsymbol{B}$. catarrhalis. Selective media designed to improve the detection of gonococci and meningococci are inhibitory for many $B$. catarrhalis strains principally due to the action of colistin $(73,81,177,325)$. Thus, only 12 strains were isolated from 1,204 throat cultures on a medium containing colistin $(6 \mu \mathrm{g} / \mathrm{ml})$ and other selective agents (325). However, a good recovery of $B$. catarrhalis and inhibition of various other species are obtained on semiselective media containing vancomycin and trimethoprim, each at final concentrations of $3 \mu \mathrm{g} / \mathrm{ml}(81,179,305)$ or higher $(93,283)$. Other semiselective media contained $25 \mu \mathrm{g}$

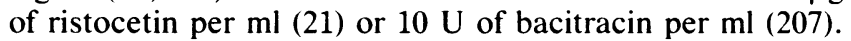
Some investigators added maltose (21), sucrose (179), or DNA (283) to facilitate differentiation of colonies. Corkill and Makin (81) initially added DNA to their semiselective medium, but found that the zone representing DNase activity around single colonies of $\boldsymbol{B}$. catarrhalis was not always easy to detect. Vaneechoutte et al. (302) improved the selective action of a sheep blood agar containing vancomycin $(10 \mu \mathrm{g} / \mathrm{ml})$, trimethoprim $(5 \mu \mathrm{g} / \mathrm{ml})$, and amphotericin B $(2 \mu \mathrm{g} / \mathrm{ml})$ by adding sodium acetazolamide $(10 \mu \mathrm{g} / \mathrm{ml})$. Incubation of this medium in air greatly reduced the growth of Neisseria species due to inhibition of the activity of carbonic anhydrase, an enzyme typically produced by Neisseria species, but not by $B$. catarrhalis $(24,37,302,307)$. The enhanced selectivity of the medium was considered responsible for the high rates of $B$. catarrhalis isolation (Table 3) since rates were far lower on semiselective media or on blood agar (302).

\section{Virulence}

Features associated with virulence in other bacteria are also present in $\boldsymbol{B}$. catarrhalis. Pili may facilitate adherence to mucosal surfaces. An outer coat analogous to a capsule and the tendency of cells to form clusters may reduce the effective actions of host defenses. The spontaneous release of outer membrane blebs provides a mechanism for the dispersal of endotoxin into peripheral tissues (285).

Studies of the virulence of clinical isolates are hampered by the low virulence of $B$. catarrhalis for laboratory animals $(113,125,130)$. Intraperitoneal inoculation of mice with enormous doses proved lethal, but the bacteria were not found in the heart blood, and death was thought to be due to the "toxic effect of the bacterial protein" (130).

Animal models of otitis media secondary to bacterial infection make use of chinchillas and gerbils. Middle-ear inoculations of $B$. catarrhalis resulted in the development of effusions. Nevertheless, viable bacteria were not recovered after $24 \mathrm{~h}(95,106)$, although elevated levels of neutral phosphatase and hexosaminidase were found in 4-day samples of chinchilla effusions (95). Killed B. catarrhalis cultures also produced effusions (106), suggesting the involvement of endotoxin in inflammatory changes seen in the middle ear (89). Experiments in which five $B$. catarrhalis isolates were added to specimens of mucoid effusion material aspirated from middle ears of young children showed that viability was retained for 18 to 36 days (291). However, conditions affecting bacterial viability in MEF from living chinchillas and in MEF following experimental inoculation are hardly comparable.

The mechanisms enabling $B$. catarrhalis to colonize the human nasopharyngeal mucous membrane are virtually unknown, but must involve adherence. Nonadherent bacteria are bathed by secretions containing antibacterial enzymes and products of local immune systems and, moreover, are likely to be swept away by the flushing effects of mucus and ciliary beating (195). Studies of adherence have demonstrated specific interactions between adhesins on bacterial surfaces and receptors on mucosal surfaces (16). The adhesins of gonococci and meningococci include pili and heatmodifiable outer membrane proteins, for example, gonococcal protein II $(285,292)$.

Investigators at Nagasaki University described interesting research on $B$. catarrhalis adherence. The text of one paper (249) is in Japanese, but the abstract, technique, and the labels and legends for figures are in English. A second study (203) is described in English. For the adherence assay, squamous epithelial cells scraped from the oropharynx were washed twice in phosphate-buffered saline to remove loosely attached bacteria and then suspended in phosphate-buffered saline containing $\mathrm{Ca}^{2+}$ and $\mathrm{Mg}^{2+}$ to give $10^{5}$ human cells per $\mathrm{ml}$. Bacteria from overnight cultures in Mueller-Hinton broth were washed, and a suspension was adjusted to an optical density of 0.1 at $620 \mathrm{~nm}$. "These suspensions contained from 1-6 $610^{7} \mathrm{CFU} / \mathrm{ml}$ " (249). The attachment mixture contained equal volumes (249) or a ratio of 1 part cells to 100 bacteria (203). After incubation for $30 \mathrm{~min}$ in a shaking $37^{\circ} \mathrm{C}$ water bath, this mixture was washed four times to eliminate nonadherent bacteria and then collected on a cover glass and Gram stained. Counts were made at $\times 1,000$ magnification of the number of attached bacteria per cell for 50 consecutive epithelial cells. The $B$. catarrhalis strains (identity confirmed by nitrate reduction) were recent isolates from respiratory infections.

Rikitomi et al. (249) studied 60 samples of oropharyngeal cells obtained from 25 patients with chronic bronchopulmo- 
nary infections. $B$. catarrhalis adhered in greater numbers to these cells than to cells from healthy persons $(P<0.001)$; the mean number of bacteria per cell ranged between seven and less than one per oropharyngeal cell from patients compared with less than one per cell from healthy adult controls. In contrast, adherence to cells from patients and control subjects was low and approximately equal for control bacteria characterized as Neisseria sp.

Mbaki et al. (203) investigated the seasonal frequency of B. catarrhalis infections in experiments with oropharyngeal cells from 48 patients who suffered from various types of chronic bronchopulmonary disease involving $B$. catarrhalis and other bacteria. The adherence of $B$. catarrhalis, in terms of mean number of bacteria per oropharyngeal cell, was highest in winter $(3.11 \pm 1.30)$ and lowest in summer $(0.40 \pm$ $0.25)$, with intermediate values in spring $(1.07 \pm 0.45)$ and autumn $(1.84 \pm 1.30)$. The value was $0.70 \pm 0.16$ for adherence to oropharyngeal cells obtained in December (winter) from nine infection-free control subjects. Mbaki et al. (203) considered that high adherence levels in winter were related to low environmental temperatures. However, low humidity in heated rooms may be more relevant since some oropharyngeal cell samples were from hospitalized patients.

A provocative observation by Rikitomi et al. (249) was the possibly greater adherence to oropharyngeal cells of $\mathrm{Bla}^{+}$ cells (two strains tested) than $\beta$-lactamase-negative cells (one strain). Unfortunately, the technical difficulty in adjusting suspensions of these $B$. catarrhalis cells to contain equal numbers of CFU per milliliter raises doubts about the validity of comparisons between strains when data are expressed as mean bacteria per cell. In view of the possibly significant differences between numbers of CFU per milliliter in the initial attachment mixtures, it would have been preferable to express results in terms of (mean number of bacteria per human cell)/(number of bacterial CFU per milliliter).

Studies of the activities of $\boldsymbol{B}$. catarrhalis in human cell cultures are needed to elucidate the complex process of infection. Adherence is required, but is not sufficient for cytotoxicity and invasion (292). $N$. lactamica cells, for example, adhere irreversibly to human cells but are not internalized (273). Upon introduction into human nasopharyngeal organ cultures, piliated meningococci attach to microvilli of nonciliated cells and in 6 to $12 \mathrm{~h}$ become trapped and pulled into membrane-bound vesicles in a manner resembling phagocytosis (204). Nearby ciliated epithelial cells, to which meningococci do not attach, soon lose ciliary activity and undergo sloughing believed due to the action of lipopolysaccharide and peptidoglycan monomers released by the cocci $(204,292)$.

$B$. catarrhalis was shown to produce histamine during growth in broth supplemented with histidine $(1 \mathrm{mg} / \mathrm{ml})$. Devalia et al. (90) speculated that this ability could contribute to the pathogenicity of such strains in the lower respiratory tract.

A mechanism for iron acquisition is a requirement for bacterial growth and, therefore, for pathogenicity (285). Iron-binding proteins present at mucosal surfaces (lactoferrin) and in blood serum (transferrin) of the human host have high association constants for iron resulting in insufficient free iron for bacterial growth. Schryvers and Lee (271) showed that $B$. catarrhalis cells possess membrane-associated proteins that bind human lactoferrin and human transferrin, thereby enabling the bacteria to utilize these sources of iron for growth. On the other hand, lactoferrin and transferrin from nonhuman species apparently are not bound, which may contribute to the specificity of B. catarrhalis for human beings.

Some clinical isolates are resistant to killing by normal human serum and others are susceptible $(46,71,282)$. The molecular basis of this complement-dependent bactericidal action in $B$. catarrhalis has not been investigated, but is presumably multifactoral as in $N$. gonorrhoeae (246).

Prellner (243) demonstrated that $B$. catarrhalis can bind the complement component $\mathrm{C} 1 \mathrm{q}$ with high efficiency without the participation of antibodies. She speculated that, in patients with acute otitis media, C1q binding might contribute to abnormal $\mathrm{C} 1$ complexes leading to impaired complement activation and defective opsonization of bacteria.

IgA1 protease was not produced by any of 45 confirmed strains of $B$. catarrhalis $(208,305)$. Koomey and Falkow (182) showed that this is due to the absence of the IgA1 protease-encoding gene in $B$. catarrhalis rather than to the presence of a silent or defective allele. IgA1 protease has been considered a virulence factor since it specifically cleaves and inactivates human IgA1, but Sparling (285) has questioned its clinical importance. Furthermore, an IgA1 protease-deficient $N$. gonorrhoeae mutant is unimpaired in its attachment to and invasion of human mucosal cells in organ culture (79).

\section{Immunity}

Circumstantial evidence of the importance of immunoglobulins as mediators of defense against $\boldsymbol{B}$. catarrhalis is found in the strong clinical association discussed earlier between various immunodeficiency states and systemic disease or bronchopulmonary infections. Furthermore, the greater susceptibility of older individuals may be due in part to the significant decline of serum IgG and IgM concentrations by the sixth decade of life (51).

The development of antibodies reactive with $B$. catarrhalis has been investigated in patients suffering from maxillary sinusitis (46), acute bronchopulmonary infections $(28,71$, 197), and acute otitis media (189). The serological methods involved immunodiffusion (46), complement fixation (46), an enzyme-linked immunoassay $(189,197)$, a bactericidal assay (71), and an immunofluorescent-antibody test (28). Modest increases of antibody titers between acute and convalescent sera occurred in most, but not all, patients. Antibodies were also detected in control sera from substantial numbers of healthy persons $(28,46,189)$, possibly due to immunogenic stimulation by $B$. catarrhalis present in the pharyngeal normal flora (189).

Leinonen et al. (189) found that IgA class antibody directed against $B$. catarrhalis developed in the sera of eight of nine children, 2 to 6 years old, who suffered from acute otitis media caused by $B$. catarrhalis. IgA antibodies were not detected in control sera from children with otitis media caused by pneumococci and $\boldsymbol{H}$. influenzae. Although half of these control sera contained IgG reactive with $B$. catarrhalis, the titers did not increase during convalescence. Middleear aspirates from which $B$. catarrhalis was cultured contained $\operatorname{IgA}$ and IgG antibodies directed against the pathogen. The presence and titers of both immunoglobulins depended on the age of the child. Using the same enzyme-linked immunoassay, Malkamäki et al. (197) detected high and rising titers of $\mathrm{IgG}$ and $\operatorname{IgA}$ antibodies in serum samples from a 19-year-old man with bacteremic pneumonia caused by $B$. catarrhalis.

B. catarrhalis is recognized as a T-cell-independent mitogen which stimulates DNA synthesis in human B lympho- 
TABLE 4. Differential biochemical reactions of $B$. catarrhalis and possibly confusing Neisseria spp. ${ }^{a}$

\begin{tabular}{|c|c|c|c|c|c|c|c|c|c|}
\hline \multirow{2}{*}{ Species } & \multicolumn{4}{|c|}{ Acid formation from: } & \multirow{2}{*}{$\begin{array}{l}\text { Polysaccharide } \\
\text { from sucrose }\end{array}$} & \multirow{2}{*}{$\begin{array}{l}\text { Reduction } \\
\text { of nitrate }\end{array}$} & \multicolumn{3}{|c|}{ Hydrolysis of: } \\
\hline & Glucose & Maltose & Lactose & Sucrose & & & $\overline{\text { DNA }}$ & Tributyrin & $\overline{\gamma-\mathrm{GNA}^{h}}$ \\
\hline B. catarrhalis & 0 & 0 & 0 & 0 & 0 & + & + & + & 0 \\
\hline N. cinerea & 0 & 0 & 0 & $\mathbf{0}$ & 0 & $\mathbf{0}$ & $\mathbf{0}$ & $\mathbf{0}$ & 0 \\
\hline N. flavescens & 0 & 0 & $\mathbf{0}$ & 0 & + & 0 & $\mathbf{0}$ & 0 & 0 \\
\hline N. gonorrhoeae & + & 0 & 0 & 0 & 0 & 0 & 0 & 0 & 0 \\
\hline$N$. meningitidis & + & + & 0 & 0 & 0 & 0 & $\mathbf{0}$ & $\mathbf{0}$ & + \\
\hline N. caviae $^{c}$ & 0 & 0 & 0 & 0 & 0 & + & + & + & 0 \\
\hline
\end{tabular}

$a+$, Most strains $(>90 \%)$ give positive reactions; 0 , negative reactions in tests with adequate controls.

${ }^{b} \gamma$-GNA, $N$ - $\gamma$-Glutamyl- $\beta$-naphthylamide.

c This organism, designated Neisseria caviae $(257,307)$ ) or Moraxella (Branhamella) caviae (37), is isolated from guinea pigs; if isolated from human sources, it might be called $B$. catarrhalis in spite of differences in DNA base composition, DNA-DNA hybridization reactions (174), genetic transformation frequencies (148), serological (24) and biochemical $(15,74,257,264,298)$ characteristics, and major cellular fatty acids (298).

cytes. This B-cell activation is related to the binding of bacteria to IgD present on the B cell. Forsgren et al. (120) offered the suggestion that B-cell binding may alter the immune response of the host and confer a selective advantage upon $B$. catarrhalis.

\section{IDENTIFICATION AND BIOCHEMICAL CHARACTERISTICS OF B. CATARRHALIS}

The appearance of bacteria in a properly Gram-stained preparation should be evaluated carefully. $B$. catarrhalis is gram negative, but has a tendency to resist decolorization (9, $23,60,245,257)$. This interaction with the crystal violet dye may be responsible for the inhibition of growth on crystal violet medium found for $B$. catarrhalis but not $N$. cinerea (4).

The bacteria characterized in Table 4 are oxidase-positive, nonmotile, gram-negative cocci commonly arranged in pairs with their abutting sides flattened. Division occurs in two planes at right angles to one another, thereby preventing chain formation which occurs when cell division is restricted to one plane (15). The potentially confusing coccobacillary cells of Moraxella and Acinetobacter species elongate into snakelike cells when division is blocked by sublethal concentrations of penicillins or certain other antibacterial agents. Since elongation does not occur with $B$. catarrhalis or Neisseria species, this is an easy way to distinguish them from nonsaccharolytic, short paired rods (63).

B. catarrhalis colonies on blood agar are nonhemolytic, circular, grayish white, opaque, convex, and $\geqq 2 \mathrm{~mm}$ in diameter after $48 \mathrm{~h}$. Colonies when pushed tend to remain intact and slide across the agar like a hockey puck on ice [P. A. Shurin, Drugs 31(Suppl. 3):38-39, 1986].

\section{Differential Tests}

Action on carbohydrates. $B$. catarrhalis does not produce acid from any of $9(69)$ or $10(112)$ carbohydrates. Negative results are observed uniformly with various methods $(9,61$, 178) including the rapid carbohydrate degradation tests designated RIM-N $(94,155,185)$, Gonobio-Test (94), and API QuadFERM ${ }^{+}(109,156)$. Minitek test reactions were correct in some instances (94), but not all (233).

Aberrant reactions in carbohydrate tests more often confuse the identification of Neisseria species. False-positive reactions in rapid glucose utilization tests were recorded for some strains of $N$. cinerea $(40,94,177)$ which led to their presumptive identification as $N$. gonorrhoeae in some cases (317). Rare meningococcal isolates are maltose negative (293). Glucose-negative reactions have been observed with meningococci and gonococci $(73,82,109,177,178,245)$. Such strains often, but not always, give positive reactions after a few subcultures on a favorable medium (212) or in a test with $10 \%$ (wt/vol) glucose, which facilitates transport of the sugar (62).

$N$. flavescens possesses an amylosucrase that builds sucrose into a polysaccharide which reacts with iodine $(20,61$, 142). This reaction differentiates $N$. flavescens from $N$. cinerea (Table 4) and $N$. polysaccharea from $N$. meningitidis $(177,258)$.

Reduction of nitrate and nitrite. $B$. catarrhalis reduces $\mathrm{NO}_{3}$ to $\mathrm{NO}_{2}$ and beyond $(22,24,37,69,73,99,256)$. The absence of both $\mathrm{NO}_{3}$ and $\mathrm{NO}_{2}$ is confirmed by the negative reaction that persists after addition of the $\mathrm{NO}_{2}$ test reagents followed by zinc dust, which reduces $\mathrm{NO}_{3}$ nonenzymatically. Berger (23) found that 0.03 to $0.01 \%$ (wt/vol) $\mathrm{NO}_{3}$, rather than the customary $0.1 \%$, provides a more sensitive test useful for revealing weak $\mathrm{NO}_{3}$ reduction. The test for $\mathrm{NO}_{3}$ reduction, when modified for use as a rapid method, was found difficult to interpret (315) or unreliable (177).

$\mathrm{NO}_{2}$ is denitrified by all species given in Table 4 provided that growth occurs. Because of $\mathrm{NO}_{2}$ toxicity, the customary $0.1 \%(\mathrm{wt} / \mathrm{vol})$ concentration should be reduced for tests of $B$. catarrhalis, $N$. cinerea, $N$. gonorrhoeae, and $N$. meningitidis. Seven $B$. catarrhalis strains were able to grow in the presence of $0.005 \%(\mathrm{wt} / \mathrm{vol}) \mathrm{KNO}_{2}$, but not $0.03 \%$; the type strain ATCC 25238 (Ne 11) tolerated 0.01\% (69). Denitrification of $\mathrm{NO}_{2}$ by $B$. catarrhalis occurs without the formation of gas $(24,25,69)$, whereas nitrogen gas is produced by $N$. cinerea and $N$. flavescens $(24,25,307)$. The test for gas production requires a large volume of broth (e.g., $25 \mathrm{ml}$ ) when $\mathrm{NO}_{2}$ is used at 0.005 or $0.01 \%$ so that enough gas will accumulate in the inverted collection vial.

Hydrolysis of DNA. The original finding of DNase production by $B$. catarrhalis (69) was confirmed by subsequent investigators who also demonstrated the differential value of the characteristic $(4,73,81,226,256)$. The customary DNase test medium contains $0.2 \%$ (wt/vol) DNA. Various reagents detect the zone of hydrolysis that develops around an area of dense bacterial growth. The Frazier reagent used in three studies $(69,73,256)$ contains mercuric chloride, $15 \mathrm{~g}$ dissolved in $100 \mathrm{ml}$ of distilled water, plus $20 \mathrm{ml}$ of concentrated hydrochloric acid. Alternatively, a solution of $0.1 \mathrm{~N} \mathrm{HCl}$ was used $(4,81)$ or toluidine blue, $0.1 \%$ (wt/vol) $(226)$.

The time of incubation can significantly affect the DNase test results. For example, one $B$. catarrhalis strain examined by Corkill and Makin (81) produced no detectable DNase activity after $24 \mathrm{~h}$, whereas an 18 -mm-diameter zone was found with a duplicate culture incubated for $48 \mathrm{~h}$. In my 
experience, the type strains $N$. cinerea ATCC $14685, N$. flavescens ATCC 13120, and N. gonorrhoeae ATCC 19424 produced $1+$ zones of DNase detected by the addition of the Frazier reagent after incubation of cultures for 4 days; $2+$ zones were found with $B$. catarrhalis ATCC 25238 and 4+ zones were found with Staphylococcus aureus (unpublished observations). For definitive results, control cultures of $B$. catarrhalis and a typically negative Neisseria species should be incubated in parallel with test cultures to enable direct comparisons of DNase zone diameters.

Hydrolysis of tributyrin and other esterase substrates. Tributyrin hydrolysis is a valuable differential characteristic $(73,154,201,247,250,257)$. The original test was relatively unsatisfactory, however, because the hydrolysis of $1 \%$ (vol/ vol) tributyrin incorporated in an agar medium (25) produced only a partial reduction of opacity that was difficult to see (256). A micromethod with $0.1 \%$ ( $\mathrm{vol} / \mathrm{vol}$ ) tributyrin in agar revealed hydrolysis by Neisseria species as well as $B$. catarrhalis (238). Recent methods take advantage of the 10 -fold-greater amount of butyric acid liberated from tributyrin by an esterase of $B$. catarrhalis than by enzymes of Neisseria species likely to be isolated from human sources (254). In one method a disk containing tributyrin and phenol red indicator is added to a dense bacterial suspension prepared in buffer solution. A positive reaction is seen as the change from red to yellow (acid $\mathrm{pH}$ ). Disk tests usually give positive results $(154,201,257)$, but negative reactions were reported for 2 of 31 isolates (109) and 1 of 28 (247) $B$. catarrhalis strains.

4-Methylumbelliferyl butyrate and indoxyl butyrate are used in place of tributyrin in other tests for esterase. Release of the 4-methylumbelliferone moiety by hydrolysis is detected by its fluorescence under UV light (301). Hydrolysis of indoxyl butyrate releases indoxyl, which spontaneously forms indigo blue (88).

Hydrolysis of aminopeptidase substrates. $N$ - $\gamma$-Glutamyl- $\beta-$ naphthylamide and L-hydroxyproline- $\beta$-naphthylamide are substrates used in rapid tests of $\gamma$-glutamylaminopeptidase and hydroxyprolylaminopeptidase, respectively. Mannheim and Bürger (199) first demonstrated that $N$ - $\gamma$-glutamyl- $\beta$ naphthylamide was hydrolyzed by $N$. meningitidis but not by $B$. catarrhalis. This was confirmed by other investigators $(84,147,255)$, who also reported negative reactions for $N$. gonorrhoeae. A purified arylamidase from " $N$. catarrhalis" which lacked activity on $N$ - $\gamma$-glutamyl- $\beta$-naphthylamide had strong activity for alanine $\beta$-naphthylamine and several other amino acid $\beta$-naphthylamines (18). The production of hydroxyprolylaminopeptidase by $N$. cinerea, but not by $B$. catarrhalis, is of possible differential value $(147,177)$. This enzyme was produced by all $N$. gonorrhoeae strains examined $(84,147,150)$ and by various percentages of $N$. meningitidis $(84,147,177)$.

Response to superoxol $\left(30 \% \mathbf{H}_{2} \mathbf{O}_{2}\right)$. All species listed in Table 4 produce catalase detected with $3 \% \mathrm{H}_{2} \mathrm{O}_{2}$. The use of $30 \% \mathrm{H}_{2} \mathrm{O}_{2}$ was recommended as a differential test (266). A positive superoxol test is seen as brisk bubbling immediately after dropping $30 \% \mathrm{H}_{2} \mathrm{O}_{2}$ onto a young ( $\left.\leq 24-\mathrm{h}\right)$ culture. Weak bubbling or a reaction delayed for $3 \mathrm{~s}$ or longer is considered negative. Positive reactions were obtained with $99.9 \%$ of $N$. gonorrhoeae isolates $(8,266,326)$. Most $N$. meningitidis strains gave negative reactions, but $98 \%$ of group A meningococci were positive (8). The superoxol test appears to lack differential value for $B$. catarrhalis since both negative and positive reactions have been reported (4, 8, 177, 326).

Other differential tests. Serological tests involving classic agglutination methods were unsuccessful due to the notorious spontaneous agglutination of $B$. catarrhalis in $0.85 \%$ $\mathrm{NaCl}$ solution $(9,24,112,130,143,245)$. Precipitin tests were used to distinguish $B$. catarrhalis from $N$. cinerea $(24$, $25)$. An immunodiffusion technique showed that one $B$. catarrhalis strain (ATCC 8176) was serologically unrelated to $N$. cinerea or to strains of eight other Neisseria species (263). Eliasson (110) investigated a trypsin-sensitive, heatstable $P$ antigen located on the surface of $B$. catarrhalis. He suggested that an antibody specific for $\mathrm{P}$ antigen might serve as a reagent for the identification of $B$. catarrhalis.

A DNA probe of chromosomal origin was developed and found to be $100 \%$ specific for B. catarrhalis $(D$. Beaulieu and P. H. Roy, Abstr. Annu. Meet. Am. Soc. Microbiol. 1989, D249, p. 124). Such a probe will reduce the time required for identification since it can be used on primary cultures with only a short pretreatment to release DNA.

Growth at $22^{\circ} \mathrm{C}$ and growth on nutrient agar have long been considered typical of $B$. catarrhalis $(4,25,82,108,117$, $212,245)$. Unfortunately, the components of nutrient agar are poorly defined and nutritionally variable (62). Additional variables (often unstated) are the inoculum density, which should be low enough to minimize spurious reactions due to carry-over of nutrients in cells grown on an adequate medium, time of incubation, and atmospheric humidity. A dry incubation atmosphere deters growth. B. catarrhalis ATCC 25238 did not grow on nutrient agar (Difco Laboratories) during incubation in an atmosphere of humidified air at either 22 or $36^{\circ} \mathrm{C}$ for 6 days, although sparse growth occurred on blood agar at $22^{\circ} \mathrm{C}$. $N$. cinerea ATCC 14685 failed to grow on either nutrient or blood agar at $22^{\circ} \mathrm{C}$, but moderate growth occurred on nutrient agar at $36^{\circ} \mathrm{C}$ (unpublished findings). The failure of 11 clinical isolates of $B$. catarrhalis to grow on nutrient agar incubated at $22^{\circ} \mathrm{C}$ led Doern and Morse (99) to recommend that this test not be included among the criteria for identification.

Some $\boldsymbol{B}$. catarrhalis strains are able to grow on modified Thayer-Martin agar and other colistin-containing selective media $(29,94,99,109,177,257,325)$. Thus, contrary to earlier findings (212), growth inhibition on these media is not a reliable differential characteristic.

Nutritional requirements were investigated by Riou and Guibourdenche (257). They found that all of 178 strains of $B$. catarrhalis required arginine for growth in Catlin's chemically defined medium (64). On the other hand, $N$. cinerea required cysteine, proline, and arginine $(180,257)$ and also histidine and biotin (unpublished findings). Juni et al. (164) independently showed the arginine requirement in a simpler defined medium and found that most strains could utilize ornithine in place of arginine. An attempt to demonstrate multiple nutritional biotypes used ion-exchange chromatography to detect the use and production of amino acids by $B$. catarrhalis grown in nutrient broth (27). The utilization of various carbon sources and additional physiological reactions were reported $(15,73)$.

Weiner and Penha (314) recently reported the value of Bacto TB Hydrolysis Reagent (Difco) as a means of detecting Tween 80 hydrolysis by $B$. catarrhalis. Negative results were obtained with 152 strains of Neisseria species and 41 strains of Moraxella species. On the other hand, lipase production detected in complex medium supplemented with $0.01 \%$ (wt/vol) Tween 80 was reported as positive for Moraxella lacunata, $M$. liquefaciens, $M$. osloensis, and Acinetobacter strains, as well as for B. catarrhalis (15). Although a potentially useful differential test, Tween 80 hydrolysis needs further evaluation. 


\section{Stages in the Identification Process}

Various commercial enzyme substrate kits for rapid tests have been described $(94,150,155,177,212,233,315)$. Unfortunately, some rapid tests yield only negative reactions for $B$. catarrhalis or, worse, false identifications (40, $94,109,233)$. Rapid tests may be justified provided that the results are rapidly communicated and the physicians fully recognize the possible provisional nature of a bacterial identification. In a survey described by Staneck (289), physicians indicated their willingness to sacrifice some degree of accuracy in return for the prompt delivery of test results. However, it is unacceptable to give a genus and species name to an isolate solely on the basis of negative reactions. A second stage in the identification process is needed.

The identity of $B$. catarrhalis is best confirmed by positive reactions in three differential tests (Table 4) since none of them is $100 \%$ sensitive or specific. Before undertaking these tests, it is important to verify the microscopic appearance and purity of the culture. The coccobacillary form of several Moraxella species that reduce $\mathrm{NO}_{3}(37)$ must be recognized (63). The possible difficulties associated with the use of inocula from a primary culture are well known, but a further example is instructive. A mixed culture obtained from a transtracheal aspirate contained $B$. catarrhalis which provided growth factors that enabled $H$. influenzae, the undetected strain, to grow and form acid in a glucose-containing medium. Accordingly, the diplococcus was initially identified as $N$. gonorrhoeae in three different laboratories (53).

The identification of atypical strains is a third stage. This may require methods used primarily in research. An organism isolated from blood cultures gave aberrant results in four tests, but was identified as an atypical strain of $\boldsymbol{B}$. catarrhalis on the basis of cell wall fatty acid and lipopolysaccharide analyses (322). DNA base composition was determined in an effort to identify oxidase-positive, nonsaccharolytic, gramnegative cocci isolated from urogenital cultures (240). The guanine-plus-cytosine content $(69 \mathrm{~mol} \%)$ proved that the isolates were not related to Branhamella or Neisseria species. Isolates of interest like these should be preserved for possible use in further studies (64).

Survey specimens were sent to "qualified reference laboratories" as part of the proficiency testing program of the College of American Pathologists. B. catarrhalis was correctly identified by $74 \%$ of 685 laboratories in 1983 and $82 \%$ of 688 laboratories in 1985 (162). This represents 125 failures to recognize $B$. catarrhalis in 1985 . (Greater respect is needed!)

\section{Strain Differentiation: Typing}

The profiles of electrophoretic mobilities of soluble proteins are of potential value for identifying and differentiating $B$. catarrhalis strains (122). Following their separation by electrophoresis through gels, proteins were stained nonspecifically with amido black $(122,123)$ or were visualized specifically with substrates for 12 metabolic enzymes (74) or with five substrates specific for esterases (235). Analysis of the profiles of $80 \mathrm{~B}$. catarrhalis strains enabled Picard et al. (235) to identify 34 esterase zymotypes and trace the spread of strains between patients with nosocomial bronchopulmonary infections.

Restriction endonuclease analysis of DNA. In restriction endonuclease typing, DNA obtained by lysis of whole cells is purified and digested with a restriction endonuclease, an enzyme that recognizes and attacks a specific DNA base sequence. This target sequence is relatively uncommon in the DNA of any given strain and is likely to differ for DNAs of unrelated strains. Agarose gel electrophoresis separates the DNA fragments produced by cleavage, and their pattern of bands is revealed by reaction with ethidium bromide.

Patterson et al. (230) used three restriction enzymes (PstI, HindIII, and HaeIII) to analyze isolates from a nosocomial outbreak of $B$. catarrhalis respiratory infections. The DNA fragment patterns were similar for strains isolated from five patients and two staff members, indicating the clonal origin of these seven isolates; different patterns were displayed by four other isolates. The same investigators (229) later examined $14 \mathrm{Bla}^{+} B$. catarrhalis strains collected over a 16-month period from other patients in the same hospital. Twelve distinct DNA fragment patterns were identified, 10 in epidemiologically unrelated strains. Identical fragment patterns were displayed by isolates from two patients located on the same ward for over 2 months.

Dickinson et al. (92) used PstI and ClaI restriction endonucleases in a study of $B$. catarrhalis isolates from the nasopharynx and MEF of seven children who experienced one or two episodes of otitis media. Strains from six of these children were unique in their DNA fragment patterns. However, in seven of eight episodes, the pair of isolates from the pharynx and middle ear had identical DNA fragment patterns, which suggested that the populations had a common origin and that these pharyngeal isolates were virulent.

A method is needed for classifying the DNA fragment patterns and identifying the variable sequences. This will facilitate the consolidation of findings from different studies and evaluation of nucleotide sequence diversity.

OMP and LOS analyses. Eight major outer membrane proteins (OMPs) of $B$. catarrhalis were characterized by Bartos and Murphy (14). The patterns of electrophoretic mobilities were similar for each of 50 strains of diverse origins. Further investigation (216) may show whether the antigenic determinants of these OMPs have the diversity required for serotyping in the way meningococci and gonococci are typed (124). In a preliminary study of lipooligosaccharides (LOS), Murphy $(215,216)$ detected antigenic differences by use of an immunoblot assay. Vaneechoutte et al. (303) developed an inhibition enzyme-linked immunosorbent assay to determine LOS antigenic differences. Three LOS types were distinguished which represented 61,29 , and $5 \%$ of 302 strains tested. No relation was discerned between the LOS type and the clinical or geographical origin of the strains.

\section{SUSCEPTIBILITY TO ANTIBACTERIAL AGENTS}

Susceptibility implies that the antibacterial agent gains access to a cellular target in a concentration sufficient to suppress a particular vital function. Antibiotics penetrate wild-type gram-negative bacteria by two routes. Outer membrane porin channels are permeable to hydrophilic solutes of relatively low molecular weight $(<600$ in enteric bacteria) (223). Tetracyclines, chloramphenicol, and most $\beta$-lactam agents diffuse through porin channels, although passage is impaired by bulky side chains and hydrophobicity $(222,223)$. Diffusion through the phospholipid bilayer regions of the outer membrane is the principal means of entry of rifampin, erythromycin, vancomycin, fatty acids, and various other hydrophobic compounds $(213,223)$.

\section{Non- $\boldsymbol{\beta}$-Lactam Agents}

The high susceptibility to erythromycin and rifampin typical of $B$. catarrhalis is related to the considerable hydro- 
phobicity of its cell surface (131). Rifampin MICs are 0.007 to $0.25 \mu \mathrm{g} / \mathrm{ml}(49,103)$. The range of erythromycin MICs, which was 0.02 to $0.3 \mu \mathrm{g} / \mathrm{ml}$ in 1970 (166), was nearly the same in some recent studies $(7,107,259)$; in two others $(103$, 119), the range extended to $1.0 \mu \mathrm{g} / \mathrm{ml}$. A few erythromycinresistant strains (MICs not stated) were reported $(93,221$, 277, 313). Differences of technique, such as medium $\mathrm{pH}$ and incubation atmosphere $(47,107)$, can account for minor differences between erythromycin test results. However, genuine resistance indicated by MICs in the range 4 to 16 $\mu \mathrm{g} / \mathrm{ml}$ was recorded for a few $B$. catarrhalis strains isolated in Japan (218), The Netherlands (296), Sweden $(165,225)$, and the United States (49).

Gram-negative bacteria can gain increased resistance to erythromycin by at least two mechanisms: alteration of a protein in the $50 \mathrm{~S}$ ribosomal subunit (324) and reduced permeability of the outer membrane which provides a protective barrier against various antibiotics $(191,222)$. The characteristics of two erythromycin-resistant $B$. catarrhalis strains described by Kallings (165) (her strains 1 and 7) suggest to me that their mechanisms of resistance differed. Strain 1 displayed low MICs (micrograms per milliliter) of penicillin V $(\leq 0.125)$, ampicillin $(\leq 0.064)$, cefaclor $(\leq 0.25)$, doxycycline $(\leq 0.125)$, and trimethoprim (TMP)-sulfamethoxazole (SMX; 0.5), but the MIC of erythromycin was 4 $\mu \mathrm{g} / \mathrm{ml}$. These characteristics are compatible with the idea that strain 1 carries a mutation that specifically affects the erythromycin target. Strain 7 , which is also $\beta$-lactamase negative, displays high MICs (micrograms per milliliter) of penicillin $\mathrm{V}(>8)$, ampicillin $(0.5)$, cefaclor (4), doxycycline $(0.5)$, and TMP-SMX (16), in addition to erythromycin $(>8)$. Such multiple resistances suggest that the strain may carry one or more mutations that result in reduced permeability. Unaccountably, these levels of resistance of strain 7 are similar to those of strain 2 which produces $\beta$-lactamase. In this connection, it is important to recognize that $\beta$-lactamase production is a trait that may be superimposed upon genetically atypical strains.

Differences in susceptibility to fatty acids and lipids also indicate outer membrane permeability differences. Free fatty acids naturally present in culture media are inhibitory to the growth of many $N$. gonorrhoeae strains, and this toxicity is neutralized by starch $(64,213)$. Arko and Odugbemi (8) examined seven $B$. catarrhalis strains and observed that the growth of three was suppressed on an area of a starchcontaining medium that had been exposed to alpha-amylase. They suggested that digestion of the starch eliminated its detoxifying action. It would be interesting to determine the response to fatty acids in a more controlled study of additional strains.

Tetracycline resistance (MIC, $16 \mu \mathrm{g} / \mathrm{ml}$ ) was detected in 1988 in two B. catarrhalis isolates from Texans with chronic lung disease (49). Previously, the highest MICs were $\leq 0.5$ $\mu \mathrm{g} / \mathrm{ml}$ reported in three surveys $(7,251,259)$ and $1.0 \mu \mathrm{g} / \mathrm{ml}$ in another (103). For the related drug doxycycline, MICs ranged between $\leq 0.125$ and $4 \mu \mathrm{g} / \mathrm{ml}$ in Sweden $(165,225)$, but were $\leq 1 \mu \mathrm{g} / \mathrm{ml}$ in Spain (119) and 0.06 to $0.25 \mu \mathrm{g} / \mathrm{ml}$ in Australia (251).

Chloramphenicol MICs fell within the range of 0.25 to 1.0 $\mu \mathrm{g} / \mathrm{ml}$ for isolates in the United States $(7,103,259)$ and Spain (119), but were as high as $4 \mu \mathrm{g} / \mathrm{ml}$ in Sweden (165).

TMP MICs have ranged between 4 and $>64 \mu \mathrm{g} / \mathrm{ml}(3,10$, $99,252,294,302)$ and SMX MICs were reported to be 2 to 32 $\mu \mathrm{g} / \mathrm{ml}$ (252). The target of TMP is dihydrofolate reductase, and in $B$. catarrhalis the affinity of TMP for enzyme is weak (10). The TMP/SMX combination is more effective than either agent alone $(3,252)$ due to the inhibitory actions of TMP and SMX on different steps in the vital pathway of folate biosynthesis (reviewed in reference 67). Most strains are susceptible $(103,121,193)$ and display TMP/SMX MICs within the range $0.02 / 0.4$ to $1.6 / 30 \mu \mathrm{g} / \mathrm{ml}(7,49,259,299)$. Rare strains were considered resistant $(86,93,313)$ and MICs of $4.0 / 76 \mu \mathrm{g} / \mathrm{ml}$ were reported (299). Since TMP is less active than SMX, the optimum ratio for most $B$. catarrhalis strains is not $1: 20$, the ratio for a commercially available TMP/SMX combination, but is closer to $2: 1$ or $1: 1$ (252) or $1: 4(165)$.

Vancomycin can be used in selective media for B. catarrhalis because the typical range of MICs is 32 to $128 \mu \mathrm{g} / \mathrm{ml}(99$, 302). Reports from one group $(7,140)$, however, gave the lower limit as a MIC of $<0.5 \mu \mathrm{g} / \mathrm{ml}$. This suggests that some isolates may represent hypersusceptibility mutants, like those of $N$. gonorrhoeae (181), which would fail to grow on vancomycin-containing selective media.

Colistin susceptibility was considered typical of $B$. catarrhalis in the 1970s (99). Although many recent isolates are susceptible $(73,283)$, others are sufficiently resistant to enable them to grow on selective medium containing colistin at $7.5 \mu \mathrm{g} / \mathrm{ml}(81,99,109)$. A correlation between increased resistance to colistin and $\beta$-lactamase production was observed $(81,99)$, but was not confirmed in another study (3).

The inhibitory concentrations of 11 heavy-metal ions for 56 strains of $B$. catarrhalis were determined by an agar dilution method. Riley and Taylor (253) found that only $10 \%$ of the strains were inhibited by $0.1 \mathrm{M}$ molybdenum, whereas $100 \%$ were inhibited by $0.0001 \mathrm{M}$ cadmium ions. The strains were not equally susceptible to a given metal ion, but all strains were inhibited by $0.001 \mathrm{M}$ each silver and mercury, $0.01 \mathrm{M}$ cobalt, and $0.1 \mathrm{M}$ each arsenate, chromium, iron, lead, manganese, and nickel ions. Resistance to multiple metal ions which characterized many strains was unrelated to $\beta$-lactamase production.

\section{Unequal Susceptibility of $\beta$-Lactamase-Negative Strains to $\beta$-Lactam Agents}

As with equality (some individuals are more equal than others), so it is also true of susceptibility that some strains are more susceptible than others. Thus, Kamme (166) found 60-fold differences between ampicillin MICs (range, 0.005 to $0.3 \mu \mathrm{g} / \mathrm{ml}$ ) and penicillin G MICs (range, 0.01 to $0.6 \mu \mathrm{g} / \mathrm{ml}$ ) for confirmed " $N$. catarrhalis" strains isolated in 1969 from children with otitis media and purulent rhinitis. More recent studies of strains lacking $\beta$-lactamase found ampicillin MICs (micrograms per milliliter) as high as $0.5(165), 0.78(267), 1.0$ $(225)$, and $>4(85)$, and Davies et al. (87) recorded a cefuroxime MIC of 16 for one isolate in a study that established the range as 0.25 to $1 \mu \mathrm{g} / \mathrm{ml}$ for 17 other isolates from patients with bronchitis.

The targets of $\beta$-lactam antibiotics are penicillin-binding proteins that catalyze the final stages of peptidoglycan biosynthesis (286). Mutations that reduce the affinity of binding proteins for penicillins lead to increased resistance. Other mutations that affect the outer membrane may increase resistance to penicillin by reducing permeability (191, 222). Although the levels of resistance may not be dramatically increased by these structural modifications, they should not be disregarded. The chromosomally mediated resistance in $N$. gonorrhoeae is a clinically important form of penicillin resistance in $\beta$-lactamase-negative strains (286). Therefore, when analyzing results of $B$. catarrhalis susceptibility tests, it is important to separate $\beta$-lactamase-negative 
strains from those producing $\beta$-lactamase in view of their differing mechanisms of resistance. Furthermore, potentially significant genetic differences between strains may be concealed by MICs considered for clinical purposes to indicate susceptibility.

This is illustrated in the interesting study by Sweeney et al. (299) of $10 \mathrm{~B}$. catarrhalis isolates from patients with pneumonia (referred to as $\mathrm{P}$ strains) and 15 isolates that colonized healthy adults ( $C$ strains). Two $P$ and three $C$ strains were $\beta$-lactamase negative. The MICs of six penicillins and seven cephalosporins, determined by a standard broth macrodilution method, showed that the five strains were susceptible according to the accepted interpretative breakpoints. Combining the results for the $\beta$-lactamasenegative and $\mathrm{Bla}^{+}$strains led to the conclusion that the susceptibilities of the $10 \mathrm{P}$ strains did not differ significantly from those of the $15 \mathrm{C}$ isolates (299).

On the other hand, if the data for the $\beta$-lactamase-negative strains are considered separately, the MICs (expressed as geometric means) reveal susceptibility differences of potential genetic significance. For example, the penicillin G MICs for the $P$ and $C$ isolates were 0.06 and $2.52 \mu \mathrm{g} / \mathrm{ml}$, respectively, a 42-fold difference. For both ampicillin and piperacillin, the MICs were $0.06 \mu \mathrm{g} / \mathrm{ml}$ for the $P$ isolates and 1.59 $\mu \mathrm{g} / \mathrm{ml}$ for $\mathrm{C}$ isolates, a 26 -fold difference. The best example is the 53-fold difference between the MICs of mezlocillin, $0.06 \mu \mathrm{g} / \mathrm{ml}$ for $\mathrm{P}$ and $3.17 \mu \mathrm{g} / \mathrm{ml}$ for $\mathrm{C}$ isolates. Investigations of many more $\beta$-lactamase-negative strains are needed as a basis for definitive conclusions. However, real differences between the geometric mean MICs might indicate differences between the outer membrane compositions of $\mathrm{P}$ and $\mathrm{C}$ isolates that could be of potential medical importance, for example, by affecting the adhesions responsible for adherence to host mucosal surfaces $(249,292)$. It should be noted that Soto-Hernandez et al. (282) reported ampicillin MICs of $0.008 \mu \mathrm{g} / \mathrm{ml}$ for six $\beta$-lactamase-negative isolates: three from patients who met the criteria for bronchopulmonary disease and three from patients who did not meet these criteria (so-called colonizing strains). However, the strains colonizing patients may differ from $\mathrm{C}$ strains isolated from healthy adults.

\section{及-Lactamase-Positive Strains}

Detection methods. Biological methods detect $\beta$-lactamase by its reduction of the antibacterial effectiveness of a penicillin or cephalosporin for a susceptible indicator strain. Biochemical methods detect enzymatic cleavage of the $\beta$-lactam ring (101). Nitrocefin and PADAC are cephalosporins that undergo color changes from yellow to red and purple to yellow, respectively, in positive tests for $\beta$-lactamase. An acidometric method detects the acid $\mathrm{pH}$ that develops when penicillin is hydrolyzed to penicilloic acid. A positive reaction in the iodometric test with penicillin is seen as a color change of the starch-iodine indicator from blue to colorless when iodine is bound by the $\beta$-lactam cleavage product.

The results obtained with these methods are not equally reliable $(101,156,234)$. For example, one $B$. catarrhalis strain that produces a low level of $\beta$-lactamase was sent to laboratories as part of the 1983 proficiency survey by the College of American Pathologists. Only the nitrocefin assay gave an acceptable percentage $(96 \%)$ of positive results. The percentages detected in other tests were as follows: acidometric, 78\%; PADAC, 69\%; iodometric, 64\% (162). The superior performance of the nitrocefin test is related to the higher rate of hydrolysis of nitrocefin compared with that of penicillin by $B$. catarrhalis.

Prevalence. Strains isolated before 1970 were susceptible to penicillin $(12,15,33,69,78,245)$ and did not produce $\beta$-lactamase (4). $\beta$-Lactamase also was not detected in $46 B$. catarrhalis strains isolated between 1970 and 1976 in France (234), 18 isolates from patients in the United States between 1952 and 1975 (311), or 5 from Japanese patients in 1976 to 1979 (218).

Two strains isolated in 1976 (Table 5) produced an enzyme identified as the BRO-1 $\beta$-lactamase (311). In Sweden (198), England (231), France (56), and Belgium (224), 及la $^{+}$strains were detected in 1977. Interestingly, in southern Netherlands, which lies next to Belgium, a $\mathrm{\beta la}^{+}$strain was not isolated until February 1980 in spite of a "constant search" (86), but the frequency rose to over $60 \%$ by 1985 to 1986. $\beta$-Lactamase was detected in $46 \%$ of 250 isolates from Swedish outpatients in 1983 (121). In Nagasaki, Japan, the $\mathrm{Bla}^{+}$strains reached $50 \%$ in 1980 and $1981,61 \%$ in 1982 , and $74 \%$ in 1983 (218). In Beijing, China, 25 (83\%) of 30 isolates were reported in 1988 (329), and in Western Australia the percentage of $\boldsymbol{B}$. catarrhalis $\mathrm{Bla}^{+}$isolates from bronchopulmonary infections doubled between 1982 and 1985 (93). Furthermore, although the prevalence of $B$. catarrhalis in acute otitis media of Finnish children remained approximately $7 \%$, the $\beta_{1 a}{ }^{+}$isolates increased from 30 to $71 \%$ between 1980 and 1985 (265). A national collaborative study of $B$. catarrhalis strains submitted by 15 U.S. medical centers found that $84 \%$ of 378 respiratory isolates were $\mathrm{Bla}^{+}$ in 1987 to 1988 (J. H. Jorgensen, L. A. Maher, A. W. Howell, J. S. Redding, and G. V. Doern, Progr. Abstr. 29th Intersci. Conf. Antimicrob. Agents Chemother., abstr. no. 1286, 1989).

The rising frequency of $\beta_{1 a}^{+}$strains has been attributed to the selective action of $\beta$-lactam agents used for treatment. However, community-acquired $\beta^{+}{ }^{+}$strains are the sources of some bronchopulmonary infections $(86,200,207,229)$ and most cases of acute otitis media. Furthermore, two recent studies show that $\beta \mathrm{Ia}^{+}$B. catarrhalis strains are carried by healthy children. $\beta$-Lactamase was detected in $78 \%$ of 94 isolates from Belgian school children (302) and in $57(54 \%)$ of 105 isolates from day-care children in Sweden (210). Thirtyone of these Swedish $\mathrm{\beta la}^{+}$carriers had not received antibiotics during the previous 6 months.

Problems in determination of resistance to $\beta$-lactam antibiotics. The formation of bacterial clusters is a source of technical difficulty in quantitative susceptibility tests. For example, aberrant killing curves were obtained in a study of the activity of a new cephalosporin against 10 strains of $\mathrm{Bla}^{+}$ $B$. catarrhalis. A massive decline of CFU per milliliter occurred during $6 \mathrm{~h}$ of incubation, but this was followed after 24 and 48 h by "regrowth," i.e., an increase of CFU to reach the number attained by the drug-free control culture (327). One possible explanation for regrowth (66) is that vortex mixing of the broth deposited clusters of cells on the glass above the fluid level, out of reach of the cephalosporin. Subsequent vortexing reintroduced viable cells into the broth in which the effective cephalosporin concentration was reduced by $\beta$-lactamase.

The results of susceptibility tests represent the outcome of complex interactions among (i) the cell, its physiological state, relative permeability, and penicillin-binding proteins; (ii) the concentration and physicochemical characteristics of the $\beta$-lactamase; and (iii) the particular antibiotic.

The outer membrane of $B$. catarrhalis is not an efficient permeability barrier (116). However, the barrier function 
TABLE 5. Prevalence of $\beta$-lactamase-producing $\left(\beta \mathrm{la}^{+}\right)$strains confirmed as $B$. catarrhalis

\begin{tabular}{|c|c|c|c|c|c|c|c|}
\hline \multirow{2}{*}{ Reference } & \multirow{2}{*}{ Place } & \multirow{2}{*}{ Yr } & \multirow{2}{*}{ Source of cultures ${ }^{a}$} & \multirow{2}{*}{ Detection method ${ }^{b}$} & \multicolumn{3}{|c|}{ No. of strains } \\
\hline & & & & & $\overline{\text { Total }}$ & $\mathrm{Bla}^{+}$ & $\%$ \\
\hline 311 & Arizona & 1976 & Sputum & Ncef & $\mathrm{NS}^{c}$ & 1 & \\
\hline 311 & Puerto Rico & 1976 & Conjunctiva & Ncef & NS & 1 & \\
\hline 198 & Sweden & 1977 & Nasopharynx, children & Ncef, iodo & 53 & 2 & 3.8 \\
\hline 224 & Belgium & 1977 & TA, BPI & Ncef & 15 & 1 & 6.7 \\
\hline \multirow[t]{3}{*}{294} & The Netherlands & 1980 & Sputum, BPI & Ncef or biol & 27 & 2 & 7.4 \\
\hline & & 1981 & & & 50 & 19 & 38.0 \\
\hline & & 1982 & & & 42 & 20 & 47.6 \\
\hline \multirow[t]{2}{*}{85} & The Netherlands & 1981 & Sputum, BPI & Ncef & 307 & 66 & 21.5 \\
\hline & & 1983-1984 & & & 737 & 355 & 48.2 \\
\hline 86 & The Netherlands & $1985-1986$ & Sputum, BPI & Ncef & NS & NS & $63-70$ \\
\hline \multirow{3}{*}{206} & Scotland & $1981-1982$ & Sputum, BPI & Ncef & 96 & 42 & 43.8 \\
\hline & & 1983 & & & 116 & 68 & 58.6 \\
\hline & & 1984 & & & 44 & 34 & 77.3 \\
\hline 269 & Denmark & 1986 & TA, sputum, BPI & Biol or Ncef & 106 & 52 & 49.1 \\
\hline 234 & France & $1981-1985$ & Sputum, pharynx & Ncef, iodo, acid & 134 & NS & 56.8 \\
\hline 277 & New Zealand & $1980-1982$ & Sputum, BPI & Acid, Ncef & 99 & 38 & 38.4 \\
\hline \multirow[t]{3}{*}{279} & New Zealand & 1983 & Sputum, BPI & Acid & NS & 2 & 2.7 \\
\hline & & 1984 & & & NS & 13 & 18.6 \\
\hline & & 1985 & & & 22 & 11 & 50.0 \\
\hline 313 & Australia & 1984 & Sputum, BPI & Ncef & 13 & 7 & 53.8 \\
\hline 267 & Japan & $1983-1984$ & Sputum, BPI & Ncef, acid & 47 & 29 & 61.7 \\
\hline 160 & California & 1978-1979 & Sputum, BPI & Ncef & 7 & 5 & 71.4 \\
\hline 274 & Ohio & $1980-1982$ & MEF, children & Biol & 26 & 20 & 76.9 \\
\hline \multirow[t]{2}{*}{305} & Ohio & 1982-1984 & MEF, children & Ncef & 61 & 46 & 75.4 \\
\hline & & & Throat, children & & 63 & 46 & 73.0 \\
\hline 7 & Tennessee & $1982-1983^{d}$ & TA, sputum, BPI & Ncef & 53 & 46 & 86.8 \\
\hline 283 & Tennessee & $1983-1986$ & Sputum & Ncef & 31 & 24 & 77.4 \\
\hline 241 & Texas & 1983-1985 & TA, sputum, BPI & Ncef & 220 & 158 & 71.8 \\
\hline 119 & Spain & $1986-1987^{d}$ & TA, sputum, BPI & Iodo & 61 & 47 & 77.0 \\
\hline \multirow[t]{2}{*}{302} & Belgium & 1987 & BPI & Ncef & 83 & NS & 69.8 \\
\hline & & 1988 & Oral, school children & & 94 & 73 & 77.7 \\
\hline
\end{tabular}

${ }^{a}$ TA, Transtracheal or endotracheal aspirates; BPI, bronchopulmonary infections; MEF, middle-ear fluid.

${ }^{b}$ Ncef, Nitrocefin; iodo, iodometric; biol, biological; acid, acidometric.

c NS, Not stated.

${ }^{d}$ Date of isolation given in related paper or estimated from the date manuscript was submitted.

may be increased by mutation, and the ensuing reduced permeability will limit entry of antibiotics into the periplasmic space and lead to increased resistance. A second barrier is provided by $\beta$-lactamase which amplifies the resistance to $\beta$-lactam agents (222). The result is the maintenance of a periplasmic concentration low enough to permit the continuing action of peptidoglycan-synthesizing enzymes in spite of a potentially inhibitory $\beta$-lactam concentration in the external environment.

Susceptibility test results are affected by the physiological state of the inoculum and the composition of the antibioticcontaining medium. These factors may partly explain the differences shown in Table 6 between the ranges of benzylpenicillin MICs in tests with media containing or lacking blood which were recorded by Doern and colleagues (100, 103) and Dunkin et al. (107). The use of media supplemented with cysteine resulted in reduced activity of amoxicillin/ clavulanic acid (281).

Inoculum density is another factor that significantly affects the MIC determined for $\mathrm{Bla}^{+}$strains $(102,111,160,184$, 231). Differences between the number of cells spot inoculated on agar media may account to some extent for differences between the results reported by Doern and Tubert (103) (Table 6) and Yokota et al. (323) (Table 7) for antibiotics that are readily hydrolyzed. A better correspondence is seen in the values reported by these authors for MICs of cefotaxime and other antibiotics that are comparatively resistant to inactivation by $\beta$-lactamase. The inoculum effect in broth (2-ml final volume) dilution tests was most conspicuous with relatively susceptible $\beta_{1 a^{+}}$strains tested at high densities (102). For example, in tests of five strains with ampicillin, inocula of $10^{4} \mathrm{CFU} / \mathrm{ml}$ gave MICs of $0.025 \mu \mathrm{g} / \mathrm{ml}$, whereas with $10^{7} \mathrm{CFU} / \mathrm{ml}$ the MICs ranged between 0.4 and $3.2 \mu \mathrm{g} / \mathrm{ml}$.

B. catarrhalis strains characterized by an ampicillin MIC of $\leq 0.25 \mu \mathrm{g} / \mathrm{ml}$ were considered susceptible (162) or, more recently, MICs ranging between 0.125 and $0.5 \mu \mathrm{g} / \mathrm{ml}$ were defined as moderately susceptible (97). A peculiarity of $\mathrm{\beta la}^{+}$ strains is that some appear to be susceptible. Ampicillin MICs of $0.03(103), 0.06(101),<0.125(7)$, and $\leq 0.125(85$, $184,259,267) \mu \mathrm{g} / \mathrm{ml}$ were reported for $\beta_{1 a}^{+}$strains. Significantly, two strains with ampicillin MICs of $0.064 \mu \mathrm{g} / \mathrm{ml}$ hydrolyzed nitrocefin at only $60 \%$ of the mean value found for 13 strains with ampicillin MICs of $\geq 0.25 \mu \mathrm{g} / \mathrm{ml}$ (295). Two other aberrant $B$. catarrhalis strains were $\beta$-lactamase negative by the nitrocefin disk test, but were recognized as $\beta \mathrm{la}^{+}$when cell extracts were tested with nitrocefin solution (193). Both strains produced a $\beta$-lactamase identified as the 1908 type (now designated BRO-2; see below) and were more susceptible to six $\beta$-lactam antibiotics than strains that produced $\beta$-lactamases of the Ravasio (BRO-1) type.

The idea (193) that cellular production of BRO-2 activity might be less than that of BRO-1 was confirmed by Wallace et al. (311). The mean activity of BRO-1 $\beta$-lactamase in cell-free extracts from 11 clinical strains was $149.1 \pm 56.5$ (standard deviation) $\mathrm{nmol}$ of nitrocefin per min per $\mathrm{mg}$ of 
TABLE 6. MICs of $\beta$-lactam antibiotics reported for $\beta$-lactamase-positive $\left(\beta \mathrm{a}^{+}\right) B$. catarrhalis

\begin{tabular}{|c|c|c|c|c|c|c|}
\hline \multirow{2}{*}{ Authors (reference) } & \multirow{2}{*}{$\begin{array}{l}\text { No. of } \\
\text { strains }\end{array}$} & \multirow{2}{*}{ Test medium ${ }^{a}$} & \multirow{2}{*}{$\mathrm{CFU}$ in inoculum } & \multirow{2}{*}{ Antibiotic $^{b}$} & \multicolumn{2}{|c|}{$\operatorname{MIC}(\mu \mathrm{g} / \mathrm{ml})$} \\
\hline & & & & & Range & Geometric mean \\
\hline \multirow[t]{2}{*}{ Doern et al. (100) } & 11 & M-H agar with $5 \%$ heated blood & $10^{4 c} / \mathrm{spot}$ & Pen & $1.25-40$ & 10.1 \\
\hline & & & & Ampicillin & $0.32-5.0$ & 1.5 \\
\hline \multirow[t]{10}{*}{ Doern and Tubert (103) } & 58 & M-H agar & $104 /$ spot & Pen & $0.015-4.0$ & 0.74 \\
\hline & & & & Ampicillin & $0.03-4.0$ & 0.89 \\
\hline & & & & Carbenicillin & $0.25-16$ & 2.0 \\
\hline & & & & Ticarcillin & $0.5-4.0$ & 1.4 \\
\hline & & & & Piperacillin & $0.125-1.0$ & 0.25 \\
\hline & & & & Cephalothin & $1.0-8.0$ & 4.1 \\
\hline & & & & Cefuroxime & $0.5-4.0$ & 1.5 \\
\hline & & & & Cefotaxime & $0.06-2.0$ & 0.38 \\
\hline & & & & Cefoxitin & $0.125-1.0$ & 0.23 \\
\hline & & & & Amox/Clav (2:1) & $0.007-0.25$ & 0.06 \\
\hline Dunkin et al. (107) & 35 & Agar with $4 \%$ lysed blood & $10^{4} /$ spot & Pen & $0.06-16$ & $\mathrm{NS}^{d}$ \\
\hline \multirow{6}{*}{ Philippon et al. (234) } & 49 & Agar & $3 \times 10^{3}-5 \times 10^{3} / \mathrm{spot}$ & Pen & $2.0-32$ & 9.78 \\
\hline & 46 & & & Amox & $0.5-32$ & 2.86 \\
\hline & & & & Clav & $8-128$ & 30.27 \\
\hline & & & & Sulbac & $1-32$ & 5.38 \\
\hline & & & & Amox/Clave & $0.12-0.5$ & 0.14 \\
\hline & & & & Amox/Sulbac ${ }^{e}$ & $0.12-0.5$ & 0.15 \\
\hline
\end{tabular}

\footnotetext{
a M-H, Mueller-Hinton.

b Pen. Benzylpenicillin; Amox, amoxicillin; Clav, clavulanate: Sulbac, sulbactam.

c Bacteria were incubated in Mueller-Hinton broth for several hours, thereby generating log-phase cells for inoculation.

d NS, Not stated.

- Fixed concentration of inhibitor, $5 \mu \mathrm{g} / \mathrm{ml}$.
}

protein, with a range of 60.4 to 217.4 . The mean value for BRO-2 extracted from nine isolates was $65.5 \pm 43.1 \mathrm{nmol}$ of nitrocefin per min per $\mathrm{mg}$ of protein (range, 29.0 to 167.7; but only one extract had activity in excess of 100 ).

The production of $\beta$-lactamase does not necessarily translate into resistance in the host (97). Infections by some $\beta$ la ${ }^{+}$ $B$. catarrhalis strains have been treated successfully with benzylpenicillin, ampicillin, or amoxicillin $(98,160,200)$. On the other hand, failures in the treatment of children with acute otitis media occurred in some cases of $B$. catarrhalis infection with $>10^{4} \mathrm{CFU} / \mathrm{ml}$ (310). Johnsson and Brorson (161) found significant differences among the relative rates of hydrolysis of ampicillin, cefaclor, and cefuroxime by intact $\mathrm{\beta la}^{+}$cells tested at $\mathrm{pH} 6$ and 8 . This might affect the outcome of treatment of an infection of the maxillary sinus or middle ear where the $\mathrm{pH}$ may be nonphysiological (47). In view of the uncertainties regarding the number of bacteria, the concentrations of $\beta$-lactamases and antibiotic, and the environmental conditions at the site of infection, it is expedient in the clinical situation to consider that a $\beta \mathrm{la}^{+}$strain is likely to be unaffected by $\beta$-lactam agents that can be cleaved by the $\beta$-lactamase.

Genetic features. The production of $\beta$-lactamase is apparently constitutive in $B$. catarrhalis $(56,115,276,295)$. The precautions needed to confirm the absence of induction are given by Bush and Sykes (55).

The genetic determinant of $\beta$-lactamase, bla, is thought to be located on the chromosome. This conclusion was originally based on the inability of investigators to visualize plasmid DNA in lysates of various ${\beta \mathrm{la}^{+}}^{+}$strains $(56,100,160$, $229,230,237,294,304)$. These negative findings may have been due to preparative difficulties (17) and the low percentage of plasmid-carrying strains $(17,311)$. Recently, bands of extrachromosomal DNA have been detected in B. catarrhalis $(17,167,170,311)$ and also in several Moraxella species $(167,311)$.

It is important to note, however, that many $\beta^{+}{ }^{+} B$. catarrhalis strains lack plasmids and strains carrying plas- mids may not produce $\beta$-lactamase $(17,167,311)$. As yet, the title of the 1986 communication, "Plasmid-Mediated $\beta$-Lactamase in Branhamella catarrhalis" (167), is not justified.

A 12.2-kilobase plasmid, designated pLQ510, was isolated from the $\mathrm{Bla}^{+}$strain E22 (17). Radiolabeled, purified pLQ510 DNA, which was used as a molecular probe to screen $17 \mathrm{~B}$. catarrhalis strains, gave a positive signal with only three: strain E22, a second known plasmid carrier, and E7. The $\mathrm{Bla}^{+}$strain E7 was found in repeated tests to lack plasmid DNA. Homology was detected between the pLQ510 probe and chromosomal DNA of strain E7, but no homology was found with 11 other $\beta_{1 a}^{+}$strains. Beaulieu et al. (17) concluded that the homology did not come from the bla gene.

The $\boldsymbol{H}$. influenzae gene that encodes $\beta$-lactamase is plasmid associated, but in the majority of $\mathrm{Bla}^{+}$strains the plasmid genome is integrated into the chromosome. A possible correlation between integration and virulence was suggested by the observation that ampicillin-resistant $H$. influenzae strains carrying extrachromosomal bla displayed reduced virulence in the infant rat model compared with resistant strains carrying integrated bla sequences (214).

Kamme and co-workers in Sweden reported successful intraspecific (169) and intergeneric transfer of $\beta$-lactamase production by conjugation (170). The bla genes of $B$. $c a$ tarrhalis and $M$. nonliquefaciens donor strains were transferred to a $B$. catarrhalis recipient strain that was $\beta$-lactamase negative and resistant to rifampin and novobiocin. Recombinants were selected on a medium containing benzylpenicillin and rifampin (167). An unusual feature of $\mathrm{Bla}^{+}$ $B$. catarrhalis donor strains was their loss of ability to transfer bla unless they were subcultured on penicillincontaining medium immediately after primary isolation (170). Wallace et al. (311) confirmed the transfer of bla from donor strains of $B$. catarrhalis and $M$. nonliquefaciens to the same two $B$. catarrhalis recipient strains that had been used by Kamme et. al. (167).

The addition of $100 \mu \mathrm{g}$ of DNase I to the filter membranes that hold the mating populations and the absence of inten- 
tionally added DNA were considered sufficient to identify the mechanism of transfer as conjugation. I suggest the alternative possibility, transformation. Transformation of streptomycin resistance is known to occur between $B$. catarrhalis and strains originally designated $M$. nonliquefaciens $(33,59)$ but more recently assigned to the new species $M$. osloensis $(15,37)$.

Three testable considerations support my argument that the mechanism of the reported bla transfers could be transformation. (i) DNase activity may be lost due to proteolysis and diffusion from the filter membrane into the underlying medium. A fraction of the cells crowded on the membrane may remain competent for transformation which can occur before the end of the overnight incubation period allowed for mating and phenotypic expression. (ii) DNA released from cells spontaneously can elicit transformation. I (65) showed that the cell-to-cell transfer of $N$. gonorrhoeae chromosomal genes occurred during cocultivation of a competent recipient strain with a donor strain that lacked a conjugative plasmid; DNA was not added experimentally, but DNase abolished this transfer. Dorward et al. (104) found that a vehicle for DNA transfer was naturally elaborated membrane vesicles (blebs). Such blebs, which are also produced by $B$. catarrhalis during growth $(143,159,217)$, may provide a natural mechanism for transfer of transforming DNA between cells. (iii) The tendency of donor cells to transfer DNA may be enhanced by growth on penicillin-containing medium. $\beta$-Lactam antibiotics are known to disorganize the wall structure of gram-negative bacteria, thereby increasing permeability (191) and, possibly, the tendency for the formation of membrane blebs.

Is the worldwide increase of $\mathrm{\beta la}^{+} B$. catarrhalis since the late 1970 s due to the dissemination of one highly communicable progenitor strain? Apparently it is not. Differences between $\mathrm{Bla}^{+}$strains were demonstrated by restriction endonuclease typing $(229,230)$. Patterson et al. (229) identified 12 distinct HaeIII digestion patterns of chromosomal DNA among a group of $\beta^{+}{ }^{+}$strains.

How, then, did $B$. catarrhalis gain the ability to produce $\beta$-lactamase when historically the species was penicillin susceptible? Mutations of a preexisting, functional bla gene can produce minor changes of the enzyme product. However, interbacterial transfer must be responsible for the recent, sudden appearance of an efficient $\beta$-lactamase. The large increase in $\mathrm{Bla}^{+}$strains does not imply that large numbers of bla gene transfers occurred. Continued multiplication of the recipients of occasional transfers, especially in the presence of $\beta$-lactam agents, the genetic stability of bla in its chromosomal location, and person-to-person spread within the community and between regions by international travel can account for the high prevalence of $\mathrm{Bla}^{+}$strains.

Possible influence in mixed infections: indirect pathogenicity. In localized, mixed infections with a penicillin-susceptible pathogen and a $\beta \mathrm{la}^{+}$commensal, the $\beta$-lactamase is thought to protect the pathogen by inactivating a penicillin used for therapy. This effect has been referred to as indirect pathogenicity $(44,85,165,205,312)$. Wardle (312) found suggestive evidence of protection in a few patients with bronchopulmonary infections who showed no clinical or radiological improvement during treatment with ampicillin or amoxicillin. Penicillin-susceptible strains of pneumococci or $H$. influenzae together with $\beta_{a^{+}} B$. catarrhalis were identified in sputum specimens and $\beta$-lactamase was detected, but the antibacterial activity expected of the penicillin was absent. Subsequently, favorable therapeutic re- sponses were obtained with antibiotics to which each of the organisms was susceptible.

A mouse model was used by Renneberg and Walder (244) to study the survival of a penicillin-susceptible pneumococcal strain mixed with either of two $B$. catarrhalis strains, one $\mathrm{Bla}^{+}$and the other (control) $\beta$-lactamase negative. Threads impregnated with bacteria were implanted subcutaneously on the backs of mice, which were then treated with ampicillin by periodic injection into the hind leg. Threads were removed after $8 \mathrm{~h}$ and immersed in phosphate-buffered saline, which was immediately used for assays of CFU and ampicillin concentrations. The $\beta$-lactamase produced during the mixed infection greatly reduced the antibacterial effect of the ampicillin.

The probability of ampicillin failure in mixed infections depends in part on the characteristics and the magnitude of the populations and the $\beta$-lactamase. $B$. catarrhalis $\beta$-lactamases are membrane associated and released only in minimal amounts $(100,115,116)$. Thus, many $\beta a^{+}$strains may not release enough $\beta$-lactamase to protect other bacteria in a localized site.

\section{Characteristics of the $\beta$-Lactamases}

A recent classification placed the Ravasio and BRO-1 $\beta$-lactamases of $B$. catarrhalis in group 2c (54). Enzymes in $2 c$ hydrolyze carbenicillin at least $75 \%$ as fast as benzylpenicillin and hydrolyze cloxacillin and many cephalosporins at relatively low rates; the isoelectric point (pI) typically falls below neutrality. Investigators have characterized $\beta$-lactamases of strains isolated from patients in England $(231,276)$, France $(56,234)$, Belgium (115), The Netherlands $(294,295)$, Sweden (111), the United States $(220,305,311)$, and Japan (323). These enzymes are distinct from the plasmid genomeencoded TEM-1 $\beta$-lactamase found in $N$. gonorrhoeae, $\boldsymbol{H}$. influenzae, and Escherichia coli $(56,111,115,234,294,311)$.

A large proportion of the $\beta$-lactamase remains associated with the cell debris obtained by ultrasonication of $B$. catarrhalis cells $(111,115)$. However, the presence of $0.5 \%$ Triton $\mathrm{X}-100$ during ultrasonication results in $>90 \%$ solubilization of enzyme (116). This indicates that this $\beta$-lactamase is strongly membrane associated.

Different methods used for enzyme extraction yield different amounts of $\beta$-lactamase (275) and other cellular proteins. Crude extracts are known to contain substances that affect enzyme activity either by interacting with the enzyme itself or by interfering with its reaction with substrate compounds (276). The use of crude extracts with weak enzyme activity in many of the studies may account in part for the diversity of substrate profiles and pIs reported and for the inference by some investigators that there are a number of distinct types of $B$. catarrhalis $\beta$-lactamase, perhaps as many as five (294) or six (295). On the other hand, with the exception of strain 939 described by Stobberingh et al. (294), Kamme et al. (167) found no evidence that $B$. catarrhalis possesses more than the one type of $\beta$-lactamase which they designated BRO-1. More recently, Wallace et al. (311) classified the Ravasio-type $\beta$-lactamase as BRO- 1 and the related 1908 type as BRO-2.

Isoelectric focusing separates proteins by aligning them as sharp bands at their isoelectric points in a $\mathrm{pH}$ gradient produced electrophoretically. The $\beta$-lactamase bands are detected with nitrocefin overlays (275). Multiple, "satellite" bands often appear which are believed to represent biologically active molecules with altered net charges resulting from the loss and/or modification of specific amino acid 
TABLE 7. $\beta$-Lactam antibiotics and the $\beta$-lactamase of B. catarrhalis NNBR-8303 ${ }^{a}$

\begin{tabular}{lrcc}
\hline \multicolumn{1}{c}{ Substrate } & $V_{\max }{ }^{b}$ & $K_{m}(\mu \mathrm{M})$ & $\mathrm{MIC}(\mu \mathrm{g} / \mathrm{ml})^{c}$ \\
\hline Benzylpenicillin & 100 & 75 & 100 \\
Ampicillin & 66 & 11 & 50 \\
Carbenicillin & 77 & 3.7 & 50 \\
Ticarcillin & 51 & 26 & 25 \\
Piperacillin & 85 & 29 & 100 \\
Cloxacillin & 6 & 2.2 & 50 \\
Cephaloridine & 4 & 1.5 & 12.5 \\
Cephalothin & 8 & 2.9 & 25 \\
Cefuroxime & 18 & 155 & 0.78 \\
Cefotaxime & 8 & 147 & 0.20 \\
Cefoxitin & 1 & 7.4 & 0.20 \\
\hline
\end{tabular}

${ }^{a}$ The $\beta$-lactamase was purified by column chromatography on DEAESepharose. (Data taken from Yokota et al. [323] with permission of the publisher.)

${ }^{b}$ Maximum rate of hydrolysis of $\beta$-lactam substrate relative to that of benzylpenicillin, which is assigned a value of 100 .

c Determined in tests of one loopful (approximately $5 \mu \mathrm{l}$ ) of an overnight broth culture on sensitivity disk agar-N containing twofold dilutions of antibiotic; inoculum estimated as $10^{8} \mathrm{CFU} / \mathrm{ml}$.

residues, possibly by enzymatic action (276). The $\beta$-lactamase in a crude extract (parent enzyme) of $B$. catarrhalis $2001 \mathrm{E}$ focused as four major bands, A, B, C, and D, with pI values of $7.2,6.4,6.0$, and 5.6 , respectively (276). The activity of band A was not sufficient to permit further analyses, but B, C, and D were isolated and found to have similar substrate profiles. These differed somewhat, however, from the profile displayed by the less purified parent enzyme. Gel filtration of the parent enzyme gave a single peak of activity, corresponding to a molecular weight of 41,000. Molecular weights estimated for bands B, C, and D were $41,000,41,000$, and 36,500 , respectively.

Kinetic constants of the $\beta$-lactamase purified from strain NNBR-8303 are given in Table 7. The data also show the correlation between the antibacterial activity (MIC) of the various $\beta$-lactam substrates and their resistance to cleavage by the $\beta$-lactamase. Not shown are diffusibility differences between the antibiotics which may also affect the MIC (222). The enzyme efficiently inactivates ampicillin as shown by the high rate of hydrolysis $\left(V_{\max }\right.$ of 66$)$ and the fairly high affinity for this substrate $\left(K_{m}\right.$ of $\left.11 \mu \mathrm{M}\right)$. With cefotaxime as substrate, on the other hand, both the maximum rate of hydrolysis $\left(V_{\max }\right.$ of 8) and the substrate affinity $\left(K_{m}\right.$ of 147 $\mu M)$ are low, indicating the relative inability of the enzyme to attack cefotaxime. This is consistent with the low MIC of cefotaxime $(0.2 \mu \mathrm{g} / \mathrm{ml})$ compared with that of ampicillin $(50$ $\mu \mathrm{g} / \mathrm{ml})$. This purified $\beta$-lactamase had a pI of 5.4 and an approximate molecular weight of 33,000 (323).

$M$. nonliquefaciens strains isolated in Sweden $(111,170)$ and the United States (311) also produce $\beta$-lactamase, a trait that appears to have been acquired in the recent past. The $\beta$-lactamases from $M$. nonliquefaciens and $B$. catarrhalis resemble each other (111). Wallace et al. (311) identified isoelectric focusing patterns characteristic of BRO-1 and BRO-2 in both organisms and found that relatively similar substrate profiles were displayed by the $\beta$-lactamases from both organisms. Benzylpenicillin, ampicillin, and methicillin were hydrolyzed at approximately equal rates. The hydrolysis rates for cefaclor and nitrocefin were higher and that for cephaloridine was much lower than that for benzylpenicillin.

Clavulanic acid and sulbactam are examples of active-sitedirected, irreversible inhibitors called suicide inhibitors (55). Low concentrations of these agents inactivate $B$. catarrhalis $\beta$-lactamases $(115,234,294,323)$, including both BRO-1 and BRO-2 (116). Since suicide inhibitors protect amoxicillin from the hydrolytic action of $\beta$-lactamase, the MIC of amoxicillin plus clavulanate is lower than the MIC of either agent alone (Table 6).

The important work of sequencing the gene encoding the BRO-1 $\beta$-lactamase is under way (D. Beaulieu, L. Piche, and P. H. Roy, Progr. Abstr. 29th Intersci. Conf. Antimicrob. Agents Chemother., abstr. no. 1120, 1989). Comparisons of this sequence with those of genes encoding BRO-2 and other possibly different $\beta$-lactamases will show the extent of their divergence.

\section{STRUCTURE AND COMPOSITION OF B. CATARRHALIS}

\section{Capsule and Pili}

B. catarrhalis, like $N$. gonorrhoeae (227), produces capsules visible by electron microscopy as a fibrillar coat. The fuzzy appearance is seen in an ultrathin section of $B$. catarrhalis stained with magnesium uranyl acetate and lead citrate (illustrated in plate 10.2, Fig. 1, of the 1974 edition of Bergey's Manual [245]). Hellio et al. (143) used ruthenium red staining to show the polysaccharide composition of this fibrillar coat, which is seen here (Fig. 1c and d) as spiculelike material $(\mathrm{sp})$ projecting from the outer membrane. The aggregated (autoagglutinated) cells appear to be held by their spicules.

Pili, also called fimbriae, are filamentous appendages that extend from the outer membrane and serve as adhesins (16). Pili were not observed in electron micrographs of $B$. catarrhalis ATCC $25238^{\mathrm{T}}$ (143), ATCC 8176 (318), or ATCC 8193 (318). Preliminary observations of four clinical isolates revealed piliation (215). Wistreich and Baker (318) reported in 1971 that a strain identified as " $N$. catarrhalis" was piliated and agglutinated erythrocytes from rabbit and mouse, but not human $\left(\mathrm{O}, \mathrm{Rh}_{\mathrm{0}}+\right)$, sources. Scanning electron microscopy revealed adhesion of these cells and their pili to agglutinated mouse erythrocytes. Soto-Hernandez et al. (282) observed $4+$ hemagglutination of human group $\mathrm{O} \mathrm{Rh}^{+}$ erythrocytes by $16 \mathrm{~B}$. catarrhalis clinical isolates. Further work is needed to determine whether this disagreement concerning erythrocytes is due to structural differences of pili or of human erythrocyte receptors.

Hemagglutination was not observed with strain ATCC 25238 (282) as expected from its lack of pili (143). A feature of strain ATCC 25238 (earlier designated Ne 11) which is valuable for genetic studies is its high frequency of intraspecific transformation $(33,68)$. The absence of piliation is interesting in view of the association between piliation (indicated by distinctive colony types $[39,64]$ ) and transformability of $N$. gonorrhoeae $(65,181)$ and $M$. nonliquefaciens (39).

\section{Envelope}

The envelope or cell wall (Fig. 1a and b) resembles that of $N$. gonorrhoeae (227). Two trilaminar structures $(\mathrm{cm}$ and om) can be seen between which lie a periplasmic space and the dense peptidoglycan-containing layer (pg). The cytoplasmic membrane $(\mathrm{cm})$, which is the innermost layer, carries penicillin-binding proteins (PBPs) at its outer face (286). PBPs 1,2 , and 3 of $B$. catarrhalis have molecular weights of $77,000,68,000$, and 39,000, respectively (128). PBP 3, like $E$. coli PBP $5 / 6$, possesses a weak $\beta$-lactamase activity.

Proteins, LOS, and phospholipids are found in the outer 

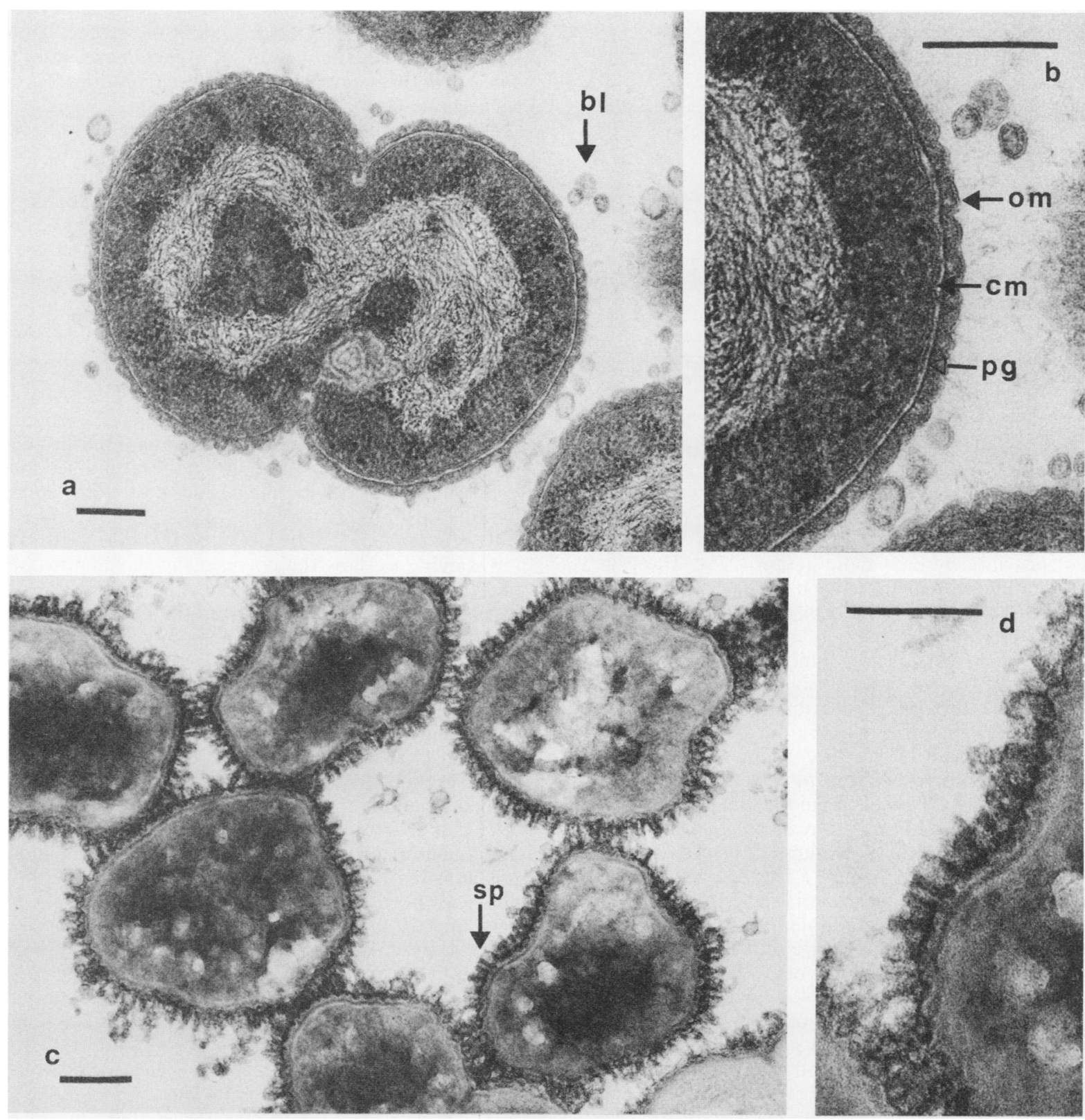

FIG. 1. Ultrastructure of B. catarrhalis ATCC $25238^{\mathrm{T}}$ seen in thin sections. (a and b) Fixation with OsO ${ }_{4}$; (c and d) ruthenium red staining. Abbreviations: bl, blebs; om, outer membrane; $\mathrm{cm}$, cytoplasmic membrane; pg, peptidoglycan-containing layer; sp, spicule-like material. Bars, $0.2 \mu \mathrm{m}$. (Reprinted from Annales de l'Institut Pasteur/Microbiology [143] with permission of the publisher.)

membrane. It should be noted that LOS is a variety of lipopolysaccharide that lacks the long, surface-exposed polysaccharide constituting the $\mathrm{O}$ antigen of smooth enteric bacteria $(133,159,303)$. The absence of $\mathrm{O}$ antigen increases outer membrane permeability, resulting in enhanced susceptibility to erythromycin, rifampin, and other hydrophobic agents $(222,223)$.

Outer membrane vesicles or blebs are released spontaneously during growth $(159,217,264)$. Their membranous appearance is evident in Fig. 1 (bl) and in the electron micrograph of outer membrane vesicles that Murphy and Loeb (217) obtained from the supernatant of a $B$. catarrhalis broth culture. Such preparations contain LOS and have a protein-binding pattern similar to that of outer membranes prepared by other methods $(159,217,264)$.
$N$. gonorrhoeae blebs are highly toxic for embryonated eggs (227). In the early literature, blebs were referred to as free endotoxin $(227,264)$ and, indeed, they function as a packaging system for the distribution of endotoxin. The toxicity is due to the biological activity of lipid A, the glycolipid component of LOS. Lipid A is anchored in the outer membrane and is covalently bound to core oligosaccharides (133). The compositions of the $B$. catarrhalis "lipopolysaccharide" and its lipid A and core oligosaccharides were reported $(1,159)$.

Eight major OMPs (OMP-A to OMP-H) whose approximate molecular weights ranged between 98,000 and 21,000 were identified in $B$. catarrhalis $(14,216,217)$. OMP-F has a molecular weight of 43,000 that is not altered by $100^{\circ} \mathrm{C}$ 
TABLE 8. DNA base compositions

\begin{tabular}{|c|c|c|c|c|c|c|}
\hline \multirow{3}{*}{ Species } & \multicolumn{6}{|c|}{$\mathrm{G}+\mathrm{C}$ content $(\mathrm{mol} \%)$ determined by: } \\
\hline & \multirow{2}{*}{$\begin{array}{l}\text { Chromatography } \\
\qquad(68,69)^{a}\end{array}$} & \multirow{2}{*}{$\begin{array}{l}\text { Buoyant density in } \mathrm{CsCl} \\
\text { (38) }\end{array}$} & \multicolumn{4}{|c|}{$T_{m}$ (thermal denaturation midpoint) } \\
\hline & & & $202^{b}$ & 148 & 261 & 258 \\
\hline \multicolumn{7}{|l|}{ B. catarrhalis } \\
\hline Strain ATCC $25238^{\mathrm{T} c}$ & $40.8^{d}$ & 41.0 & 41 & 41.3 & 41.0 & \\
\hline Other strains $e^{e}$ & $40.0-43.0$ & $41.0-42.0$ & & 41.6 & & \\
\hline$N$. cinerea & & 49.0 & & 50.9 & & 50.5 \\
\hline N. flavescens & $50.2^{d}$ & $46.5-47.5$ & 49 & & 49.6 & 50.1 \\
\hline N. gonorrhoeae & & & & 53.3 & & 53.2 \\
\hline N. meningitidis & $51.3^{d}$ & & 51.5 & 52.0 & 52.8 & 53.2 \\
\hline N. caviae & & 44.5 & & 47.3 & 46.9 & \\
\hline
\end{tabular}

${ }^{a}$ Numbers in parentheses are reference numbers.

${ }^{b}$ Reference number.

c Type strain of the species, originally designated $\mathrm{Ne} 11$

${ }^{d} \mathrm{G}+\mathrm{C}$ content was derived from the $\mathrm{A}+\mathrm{T} / \mathrm{G}+\mathrm{C}$ ratio.

e Excludes " $N$. catarrhalis" NCTC 4103, which deviates enough to suggest that the species designation may be incorrect (15, 33, 59, 69).

treatment, in contrast to OMP-C, -D, -E, -G, and $-\mathrm{H}$ which are heat modifiable (217).

Porins are proteins that typically exist as trimers forming channels through the outer membrane for passive diffusion of small hydrophilic nutrients and antibiotics (223). OMP 2 of $N$. meningitidis is a porin characterized by a molecular weight of 40,000 to 42,000 (124). In view of the relationship between response to hydrophilic antibiotics and porin function, it will be of interest to investigate the $B$. catarrhalis porin(s). I speculate that OMP-F may be a porin.

The fatty acid profiles of members of the family Neisseriaceae have been determined in various laboratories (45, $147,157,187,190,298)$, but caution is needed in comparing the results. The fatty acid content is greatly affected by the culture medium components and incubation temperature $(157,187)$. For $B$. catarrhalis cells grown on supplemented GC medium base agar, $20 \%$ of the total fatty acids were recorded as 17:1 acid (where the number left of the colon indicates the number of carbon atoms and that on the right is the number of double bonds). However, 17:1 acid was not detected in cells grown on Trypticase soy agar (187). Various authors $(147,157,187,298)$ agree that the $16: 0,16: 1$, and $18: 1$ acids are abundant in $B$. catarrhalis and several species from animals, including $N$. caviae (this species is described in Table 4 , footnote $c$ ). Nevertheless, the fatty acid profiles differ. By determining the double-bond positions $(\Delta)$ in 18:1 acids, Sugimoto et al. (298) distinguished $B$. catarrhalis $(\Delta 11$ $18: 1,64 \%$ of total fatty acids) from $N$. caviae ( $\Delta 918: 1$, $42 \%)$.

\section{DNA}

The guanine-plus-cytosine $(\mathrm{G}+\mathrm{C})$ contents of DNA preparations from $B$. catarrhalis and possibly confusing Neisseria species are given in Table 8 . The findings for a given species were in agreement, except for several values (especially for $N$. flavescens) determined by the $\mathrm{CsCl}$ gradient centrifugation method. Also, divergent $\mathbf{G}+\mathrm{C}$ values determined by a chromatographic method were reported (186) for 11 strains of $N$. caviae (range, 47.7 to $50.4 \mathrm{~mol} \%$; not included in Table 8).

Differences between the $\mathrm{G}+\mathrm{C}$ contents of $B$. catarrhalis and $N$. meningitidis DNA, for example, indicate base sequence differences sufficient to explain the absence of DNAmediated transformation of streptomycin resistance between transformable strains of these species (68), their low degree of DNA relatedness shown by DNA-DNA hybridization (174), and their lack of stable DNA duplexes (176). The " $N$. catarrhalis" genome contains approximately $2.3 \times 10^{6} \mathrm{nu}$ cleotide pairs (175). They must encode several thousand gene products. In view of the DNA differences, it is not surprising that a two-dimensional polyacrylamide gel electrophoresis system which separated 200 polypeptides from cellular extracts revealed only $9 \%$ similarity between the locations of polypeptide spots on electrophoretograms of a $B$. catarrhalis strain and a reference $N$. gonorrhoeae strain (152).

\section{WHAT'S IN A NAME?}

A scientific bacterial name should be unambiguous, recognizable in all languages, and stable $(42,280)$. "One of the annoying problems facing the practicing physician is the constant reclassification and changing names of microorganisms" (324). Although aware of the inconvenience of the name change, investigators working before 1970 recognized that substantial differences between " $N$. catarrhalis" and the "true neisseriae" mandated their separation into different genera $(1,15,33,68,146,174,190)$. This separation was validated by subsequent studies $(147,152,159,261$, 288).

Ideally, a genus is composed of species that are relatively similar phenotypically and show 50 to $65 \%$ DNA relatedness determined under conditions optimal for DNA reassociation (42). The "true neisseriae" associated with human hosts include $N$. gonorrhoeae, $N$. meningitidis, and the less pathogenic $N$. flavescens, $N$. cinerea, $N$. sicca, $N$. subflava, $N$. mucosa, and $N$. polysaccharea $(177,258,307)$. Their levels of DNA relatedness are appropriate for membership in a single genus. On the other hand, relations between these organisms and $B$. catarrhalis are minimal or absent as determined by (i) genetic transformation of streptomycin resistance $(33,68,148)$; (ii) DNA base composition (Table 8$)$; (iii) DNA homologies determined by several techniques (136, 148, 174, 176); and (iv) rRNA binding to DNA (261).

In spite of the widespread agreement that it is inappropriate to include " $N$. catarrhalis" in the genus Neisseria, the name of the genus to which the species should be transferred is controversial. Two names have been proposed: Branhamella catarrhalis (Catlin in 1970 [60]) and Moraxella (Branhamella) catarrhalis (Bøvre in 1979 [35]). The latter is an emended version of the name Moraxella catarrhalis 
which was suggested in 1968 (146) in consideration of the genetic relatedness demonstrated independently by $B \varnothing v$ re $(32,34)$ and by Catlin $(59,70)$. The extensive work of the Oslo group and their rationale for including bacterial rods and cocci in the genus Moraxella are summarized in two reviews $(39,145)$. B $\emptyset v r e$ found it expedient to divide the genus Moraxella into the subgenus Branhamella (to contain coccal organisms) and the subgenus Moraxella (to contain rod-shaped organisms). This is an awkward arrangement, however, since subgenus names are now rarely used (280), Moraxella (Branhamella) catarrhalis is unnecessarily long, and deletion of the subgenus name leaves the possibly confusing $M$. catarrhalis. The name Branhamella catarrhalis served to distinguish the organism from the so-called nonpathogenic neisseriae and focused attention on their differing potentials for pathogenicity. The proposed association with moraxellae, most of which possess only limited pathogenicity $(39,145)$, would relegate $B$. catarrhalis to an unfamiliar conglomerate of cocci and rods.

The differences revealed by DNA-rRNA hybridization are so great that Rossau et al. (261) recommended the removal of Branhamella and Moraxella from the family Neisseriaceae in which they were classified $(36,39,146)$. The genus Neisseria is now placed in the beta group of the new class Proteobacteria (a taxonomic category higher than the family), whereas Branhamella and Moraxella are in the gamma group (288). The genetic relatedness between Branhamella and Moraxella is genuine, but it can be acknowledged adequately, I believe, by assigning these genera to a new family, Branhamaceae.

\section{CONCLUSIONS AND PROSPECTS}

B. catarrhalis has finally gained respect as a pathogen thanks to the many recent reports of its causal role in a variety of infections. Much has been learned about its structural, biochemical, and differential characteristics, responses to antibacterial agents, and $\beta$-lactamases. Future studies must use strains precisely identified by standard methods. Research is needed to enhance the molecular and genetic respectability of the organism. Initial strategies may use transformation to develop isogenic strains carrying auxotrophic and antibacterial resistance markers. The possible cell-to-cell transmission of chromosomal loci mediated by DNA associated with blebs should be investigated. Knowledge of the genes and their organization in B. catarrhalis, $N$. caviae, and $M$. nonliquefaciens is needed. This will provide a sounder basis for judgment concerning the relatedness and evolution of these organisms, permit comparisons with the genetic markers of $N$. gonorrhoeae, and aid the identification of gene products.

A multifactoral problem centers around the genetic loci encoding bla, their origin, mode of transfer, features of chromosomal integration, and phenotypic effects, in addition to $\beta$-lactamase production, possibly associated with their acquisition. The rapid, worldwide increase in the percentage of $\mathrm{Bla}^{+}$strains is remarkable. In some regions this has been accompanied by rising numbers of $B$. catarrhalis infections. The increasing incidence of bronchopulmonary infections may be due in part to the greater use of immunosuppressive agents. However, this could not account for the documented increases of childhood otitis media caused by $B$. catarrhalis. Possibly the success of $\mathrm{Bla}^{+}$strains is associated with an improved mechanism of adherence to mucous membranes, especially of children, or some other virulence-associated property. Further investigations of this problem as well as the virulence of case and carrier strains and the molecular basis of pathogenesis await the development of organ cultures or animal models. The recent logarithmic increase of publications illustrates the increased awareness of $B$. $c a$ tarrhalis and growth of interest in the multitude of significant questions now apparent.

\section{ACKNOWLEDGMENTS}

Information and preprints received from D. Beaulieu, G. V. Doern, T. F. Murphy, and R. J. Wallace, Jr., are gratefully acknowledged. I especially thank Jean-Yves Riou for providing me original photographs for Fig. 1.

\section{LITERATURE CITED}

1. Adams, G. A., T. G. Tornabene, and M. Yaguchi. 1969. Cell wall lipopolysaccharides from Neisseria catarrhalis. Can. J. Microbiol. 15:365-374.

2. Ahmad, F., M. A. Calder, M. J. Croughan, and T. G. Marshall. 1985. Urinary tract infection caused by Branhamella catarrhalis. J. Infect. 10:176-177.

3. Ahmad, F., D. T. McLeod, M. J. Croughan, and M. A. Calder. 1984. Antimicrobial susceptibility of Branhamella catarrhalis isolates from bronchopulmonary infections. Antimicrob. Agents Chemother. 26:424-425.

4. Ahmad, F., H. Young, D. T. McLeod, M. J. Croughan, and M. A. Calder. 1987. Characterisation of Branhamella catarrhalis and differentiation from Neisseria species in a diagnostic laboratory. J. Clin. Pathol. 40:1369-1373.

5. Aitken, J. M., and P. E. Thornley. 1983. Isolation of Branhamella catarrhalis from sputum and tracheal aspirate. J. Clin. Microbiol. 18:1262-1263.

6. Alligood, G. A., and J. F. Kenny. 1989. Tracheitis and supraglottis associated with Branhamella catarrhalis and respiratory syncytial virus. Pediatr. Infect. Dis. J. 8:190-191.

7. Alvarez, S., M. Jones, S. Holtsclaw-Berk, J. Guarderas, and S. L. Berk. 1985. In vitro susceptibilities and $\beta$-lactamase production of 53 clinical isolates of Branhamella catarrhalis. Antimicrob. Agents Chemother. 27:646-647.

8. Arko, R. J., and T. Odugbemi. 1984. Superoxol and amylase inhibition tests for distinguishing gonococcal and nongonococcal cultures growing on selective media. J. Clin. Microbiol. 20:1-4.

9. Arkwright, J. A. 1907. On the occurance of the Micrococcus catarrhalis in normal and catarrhal noses and its differentiation from other Gram-negative cocci. J. Hyg. 7:145-154.

10. Averett, D. R., B. Roth, J. J. Burchall, and D. P. Baccanari. 1979. Dihydrofolate reductase from Neisseria sp. Antimicrob. Agents Chemother. 15:428-435.

11. Bannatyne, R. M., and V. Kolodej. 1985. Branhamella catarrhalis bacteremia and immunosuppression-part of a larger problem? Diagn. Microbiol. Infect. Dis. 3:65-67.

12. Barber, M., and P. M. Waterworth. 1962. Antibacterial activity of the penicillins. Br. Med. J. i:1159-1164.

13. Baron, J., and E. D. Shapiro. 1985. Unsuspected bacteremia caused by Branhamella catarrhalis. Pediatr. Infect. Dis. J. 4:100-101.

14. Bartos, L. C., and T. F. Murphy. 1988. Comparison of the outer membrane proteins of 50 strains of Branhamella catarrhalis. J. Infect. Dis. 158:761-765.

15. Baumann, P., M. Doudoroff, and R. Y. Stanier. 1968. Study of the Moraxella group. I. Genus Moraxella and the Neisseria catarrhalis group. J. Bacteriol. 95:58-73.

16. Beachey, E. H. 1981. Bacterial adherence: adhesin-receptor interactions mediating the attachment of bacteria to mucosal surfaces. J. Infect. Dis. 143:325-345.

17. Beaulieu, D., M. Quellette, M. G. Bergeron, and P. H. Roy. 1988. Characterization of a plasmid isolated from Branhamella 
catarrhalis and detection of plasmid sequences within the genome of a Branhamella catarrhalis strain. Plasmid 20:158162.

18. Behal, F. J., and J. D. Folds. 1967. Arylamidase of Neisseria catarrhalis. Arch. Biochem. Biophys. 121:364-371.

19. Berg, R. A., and D. L. Bartley. 1987. Pneumonia associated with Branhamella catarrhalis in infants. Pediatr. Infect. Dis. J. 6:569-573

20. Berger, U. 1961. Polysaccharidbildung durch saprophytische Neisserien. Zentralbl. Bakteriol. Parasitenkd. Infektionskr. Hyg. Abt. 1 Orig. 181:345-349.

21. Berger, U. 1961. Ein Elektivnährboden für Neisseria catarrhalis. Zentralbl. Bakteriol. Parasitenkd. Infektionkr. Hyg. Abt. 1 Orig. 183:135-138.

22. Berger, U. 1961. Reduktion von Nitrat und Nitrit durch Neisseria. Z. Hyg. Infektionskr. 148:45-50.

23. Berger, U. 1963. Die anspruchslosen Neisserien. Ergeb. Mikrobiol. Immunitaetsforsch. Exp. Ther. 36:97-167.

24. Berger, U. 1984. Serology of non-gonococcal, non-meningococcal Neisseria and Branhamella species. Methods Microbiol. 16:225-245.

25. Berger, U., and E. Paepcke. 1962. Untersuchungen über die asaccharolytischen Neisserien des menschlichen Nasopharynx. Z. Hyg. Infektionskr. 148:269-281.

26. Bergey, D. H., F. C. Harrison, R. S. Breed, B. W. Hammer, and F. M. Huntoon. 1923. Bergey's manual of determinative bacteriology, p. 43. The Williams \& Wilkins Co., Baltimore.

27. Bezjak, V., H. N. Shah, and J. Barley. 1988. Profiles of amino-acid utilisation and production amongst strains of $\mathrm{Bra}$ nhamella catarrhalis. J. Med. Microbiol. 26:143-146.

28. Black, A. J., and T. S. Wilson. 1988. Immunoglobulin G (IgG) serological response to Branhamella catarrhalis in patients with acute bronchopulmonary infections. J. Clin. Pathol. 41: 329-333.

29. Blackwell, C., H. Young, and S. S. R. Bain. 1978. Isolation of Neisseria meningitidis and Neisseria catarrhalis from the genitourinary tract and anal canal. Br. J. Vener. Dis. 54:41-44.

30. Bluestone, C. D. 1986 . Otitis media and sinusitis in children: role of Branhamella catarrhalis. Drugs 31(Suppl. 3):132-141.

31. Bonadio, W. A. 1988. Branhamella catarrhalis bacteremia in children. Pediatr. Infect. Dis. J. 7:738-739.

32. Bøvre, K. 1963. Affinities between Moraxella spp. and a strain of Neisseria catarrhalis as expressed by transformation. Brief report. Acta Pathol. Microbiol. Scand. 58:528.

33. Bøvre, K. 1965. Studies on transformation in Moraxella and organisms assumed to be related to Moraxella. 4. Streptomycin resistance transformation between asaccharolytic Neisseria strains. Acta Pathol. Microbiol. Scand. 64:229-242.

34. Bøvre, K. 1967. Transformation and DNA base composition in taxonomy, with special reference to recent studies in Moraxella and Neisseria. Acta Pathol. Microbiol. Scand. 69:123-144

35. Bøvre, K. 1979. Proposal to divide the genus Moraxella Lwoff 1939 emend. Henriksen and Bøvre 1968 into two subgenera, subgenus Moraxella (Lwoff 1939) Bøvre 1979 and subgenus Branhamella (Catlin 1970) Bøvre 1979. Int. J. Syst. Bacteriol. 29:403-406.

36. Bøvre, K. 1984. Family VIII. Neisseriaceae Prévot 1933, p. 288-290. In N. R. Krieg and J. G. Holt (ed.), Bergey's manual of systematic bacteriology, vol. 1. The Williams \& Wilkins Co., Baltimore.

37. Bøvre, K. 1984. Genus II. Moraxella Lwoff 1939, emend. Henriksen and Bøvre 1968, p. 296-303. In N. R. Krieg and J. G. Holt (ed.), Bergey's manual of systematic bacteriology, vol. 1. The Williams \& Wilkins Co., Baltimore.

38. Bøvre, K., M. Fiandt, and W. Szybalski. 1969. DNA base composition of Neisseria, Moraxella, and Acinetobacter, as determined by measurement of buoyant density in $\mathrm{CsCl}$ gradients. Can. J. Microbiol. 15:335-338.

39. Bøvre, K., and N. Hagen. 1981. The family Neisseriaceae: rod-shaped species of the genera Moraxella, Acinetobacter Kingella, and Neisseria, and the Branhamella group of cocci, p. 1506-1529. In M. P. Starr, H. Stolp, H. G. Trüper, A. Balows, and H. G. Schlegel (ed.), The prokaryotes, vol. 2.
Springer-Verlag, Berlin.

40. Boyce, J. M., and E. B. Mitchell, Jr. 1985. Difficulties in differentiating Neisseria cinerea from Neisseria gonorrhoeae in rapid systems used for identifying pathogenic Neisseria species. J. Clin. Microbiol. 22:731-734.

41. Branham, S. E., and M. J. Pelczar. 1957. Family VIII. Neisseriaceae Prévot 1933, p. 480-485. In R. S. Breed, E. G. D. Murray, and N. R. Smith (ed.), Bergey's manual of determinative bacteriology, 7th ed. The Williams \& Wilkins Co., Baltimore.

42. Brenner, D. J. 1985. Taxonomy, classification, and nomenclature of bacteria, p. 1-7. In E. H. Lennette, A. Balows, W. J. Hausler, Jr., and H. J. Shadomy (ed.), Manual of clinical microbiology, 4th ed. American Society for Microbiology, Washington, D.C.

43. Brook, I. 1981. Microbiological studies of the bacterial flora of the external auditory canal in children. Acta Oto Laryngol. 91:285-287.

44. Brook, I. 1986. Direct and indirect pathogenicity of Branhamella catarrhalis. Drugs 31(Suppl. 3):97-102.

45. Brooks, J. B., D. S. Kellogg, L. Thacker, and E. M. Turner. 1971. Analysis by gas chromatography of fatty acids found in whole cultural extracts of Neisseria species. Can. J. Microbiol. 17:531-543.

46. Brorson, J.-E., A. Axelsson, and S. E. Holm. 1976. Studies on Branhamella catarrhalis (Neisseria catarrhalis) with special reference to maxillary sinusitis. Scand. J. Infect. Dis. 8:151155.

47. Brorson, J.-E., and P. Larsson. 1985. $\mathrm{pH}$ and incubation atmosphere influence erythromycin activity against $\mathrm{Bra}$ nhamella catarrhalis. J. Antimicrob. Chemother. 15:644-645.

48. Brorson, J.-E., and B.-E. Malmvall. 1981. Branhamella catarrhalis and other bacteria in the nasopharynx of children with longstanding cough. Scand. J. Infect. Dis. 13:111-113.

49. Brown, B. A., R. J. Wallace, Jr., C. W. Flanagan, R. W. Wilson, J. I. Luman, and S. D. Redditt. 1989. Tetracycline and erythromycin resistance among clinical isolates of $\mathrm{Bra}$ nhamella catarrhalis. Antimicrob. Agents Chemother. 33: 1631-1633.

50. Bryant, J. 1983. Fatal sepsis due to Branhamella catarrhalis and Haemophilus influenzae in a child with selective IgG deficiency. Arch. Pathol. Lab. Med. 107:442.

51. Buckley, C. E., III, and F. C. Dorsey. 1970. The effect of aging on human serum immunoglobulin concentrations. J. Immunol. 105:964-972.

52. Burnett, A. K., D. J. Easton, A. M. Gordon, and R. M. Rowan. 1975. Neisseria catarrhalis septicaemia in acute lymphoblastic leukaemia. Scot. Med. J. 20:37-38.

53. Busch, D. F., D. M. Citron, and D. A. Casciato. 1979. False identification of Neisseria gonorrhoeae in lower respiratory tract secretions-result of mixed culture. Curr. Microbiol. 2:299-300

54. Bush, K. 1989. Classification of $\beta$-lactamases: groups $2 c, 2 d$, 2e, 3, and 4. Antimicrob. Agents Chemother. 33:271-276.

55. Bush, K., and R. B. Sykes. 1986. Methodology for the study of $\beta$-lactamases. Antimicrob. Agents Chemother. 30:6-10.

56. Buu Hoi-Dang Van, A., C. Brive-Le Bouguenec, M. Barthelemy, and R. Labia. 1978. Novel $\beta$-lactamase from Branhamella catarrhalis. Ann. Microbiol. (Paris) 129B:397-406.

57. Calder, M. A., M. J. Croughan, D. T. McLeod, and F. Ahmad. 1986. The incidence and antibiotic susceptibility of Branhamella catarrhalis in respiratory infections. Drugs 31(Suppl. 3):11-16.

58. Capewell, S., D. T. McLeod, M. J. Croughan, F. Ahmad, M. A. Calder, and A. Seaton. 1988. Pneumonia due to Branhamella catarrhalis. Thorax 43:929-930.

59. Catlin, B. W. 1964. Reciprocal genetic transformation between Neisseria catarrhalis and Moraxella nonliquefaciens. J. Gen. Microbiol. 37:369-379.

60. Catlin, B. W. 1970. Transfer of the organism named Neisseria catarrhalis to Branhamella gen. nov. Int. J. Syst. Bacteriol. 20:155-159.

61. Catlin, B. W. 1970. Neisseria meningitidis (meningococcus), p. 
76-81. In J. E. Blair, E. H. Lennette, and J. P. Truant (ed.), Manual of clinical microbiology. American Society for Microbiology, Washington, D.C.

62. Catlin, B. W. 1974. Neisseria meningitidis (meningococcus), p. 116-123. In E. H. Lennette, E. H. Spalding, and J. P. Truant (ed.), Manual of clinical microbiology, 2nd ed. American Society for Microbiology, Washington, D.C.

63. Catlin, B. W. 1975. Cellular elongation under the influence of antibacterial agents: way to differentiate coccobacilli from cocci. J. Clin. Microbiol. 1:102-105.

64. Catlin, B. W. 1978. Characteristics and auxotyping of Neisseria gonorrhoeae, p. 345-380. In T. Bergan and J. R. Norris (ed.), Methods in microbiology, vol. 10. Academic Press, Inc. (London), Ltd., London.

65. Catlin, B. W. 1982. Cell-to-cell transmission of chromosomal loci in Neisseria gonorrhoeae, p. 311-321. In U. N. Streips, S. H. Goodgal, W. R. Guild, and G. A. Wilson (ed.), Genetic exchange. Marcel Dekker, Inc., New York.

66. Catlin, B. W. 1984. Probenecid: antibacterial action against Neisseria gonorrhoeae and interaction with benzylpenicillin. Antimicrob. Agents Chemother. 25:676-682.

67. Catlin, B. W. 1989. Genetic basis of the association of sulphonamide resistance with methionine auxotrophy in Neisseria gonorrhoeae. J. Gen. Microbiol. 135:1101-1111.

68. Catlin, B. W., and L. S. Cunningham. 1961. Transforming activities and base contents of deoxyribonucleate preparations from various neisseriae. J. Gen. Microbiol. 26:303-312.

69. Catlin, B. W., and L. S. Cunningham. 1964. Genetic transformation of Neisseria catarrhalis by deoxyribonucleate preparations having different average base compositions. J. Gen. Microbiol. 37:341-352.

70. Catlin, B. W., and L. S. Cunningham. 1964. Transforming activities and base composition of deoxyribonucleates from strains of Moraxella and Mima. J. Gen. Microbiol. 37:353-367.

71. Chapman, A. J., Jr., D. M. Musher, S. Jonsson, J. E. Clarridge, and R. J. Wallace, Jr. 1985. Development of bactericidal antibody during Branhamella catarrhalis infection. J. Infect. Dis. 151:878-882.

72. Christensen, J. J., and B. Bruun. 1985. Bacteremia caused by a beta-lactamase producing strain of Branhamella catarrhalis. Acta Pathol. Microbiol. Immunol. Scand. Sect B 93:273-275.

73. Christensen, J. J., O. Gadeberg, and B. Bruun. 1986. Branhamella catarrhalis: significance in pulmonary infections and bacteriological features. Acta Pathol. Microbiol. Immunol. Scand. Sect. B 94:89-95.

74. Chun, P. K., G. F. Sensabaugh, and N. A. Vedros. 1985. Genetic relationships among Neisseria species assessed by comparative enzyme electrophoresis. J. Gen. Microbiol. 131: 3105-3115

75. Cimolai, N., and R. J. Adderley. 1989. Branhamella catarrhalis bacteremia in children. Acta Pediatr. Scand. 78:465-468.

76. Clarke, R. M., and R. B. Haining. 1936. Neisseria catarrhalis endocarditis. Ann. Intern. Med. 10:117-121.

77. Cocchi, P., and A. Ulivelli. 1968. Meningitis caused by Neisseria catarrhalis. Acta Pediatr. Scand. 57:451-453.

78. Coffey, J. D., Jr., A. D. Martin, and H. N. Booth. 1967. Neisseria catarrhalis in exudate otitis media. Arch. Otolaryngol. 86:403-406.

79. Cooper, M. D., Z. A. McGee, M. H. Mulks, J. M. Koomey, and T. L. Hindman. 1984. Attachment to and invasion of human fallopian tube mucosa by an IgA1 protease-deficient mutant of Neisseria gonorrhoeae and its wild-type parent. J. Infect. Dis. 150:737-744.

80. Corbett, W. P., and B. W. Catlin. 1968. Galactosidase activity of lactose-positive Neisseria. J. Bacteriol. 95:52-57.

81. Corkill, J. E., and T. Makin. 1982. A selective medium for non-pathogenic aerobic Gram negative cocci from the respiratory tract: with special reference to Branhamella catarrhalis. Med. Lab. Sci. 39:3-10.

82. Cowan, S. T. 1974. Cowan and Steel's manual for the identification of medical bacteria, 2nd ed., p. 80-83. University Press, Cambridge.

83. Cox, P. M., Jr., and E. Colloff. 1979. Neisseria catarrhalis empyema in an immunodeficient host. Am. Rev. Respir. Dis. 120:471-472.

84. D'Amato, R. F., L. A. Eriquez, K. M. Tomfohrde, and E. Singerman. 1978. Rapid identification of Neisseria gonorrhoeae and Neisseria meningitis by using enzymatic profiles. $\mathrm{J}$. Clin. Microbiol. 7:77-81.

85. Davies, B. I., and F. P. V. Maesen. 1986. Epidemiological and bacteriological findings on Branhamella catarrhalis respiratory infections in The Netherlands. Drugs 31(Suppl. 3):28-33.

86. Davies, B. I., and F. P. V. Maesen. 1988. The epidemiology of respiratory tract pathogens in Southern Netherlands. Eur. Respir. J. 1:415-420.

87. Davies, B. I., F. P. V. Maesen, and J. P. Teengs. 1987. Cefuroxime axetil in acute purulent exacerbations of chronic bronchitis. Infection 15:253-256.

88. Dealler, S. F., M. Abbott, M. J. Croughan, and P. M. Hawkey. 1989. Identification of Branhamella catarrhalis in $2.5 \mathrm{~min}$ with an indoxyl butyrate strip test. J. Clin. Microbiol. 27:1390-1391.

89. DeMaria, T. F. 1988. Endotoxin and otitis media. Ann. Otol. Rhinol. Laryngol. 97:31-33.

90. Devalia, J. L., D. Grady, Y. Harmanyeri, S. Tabaqchali, and R. J. Davies. 1989. Histamine synthesis by respiratory tract micro-organisms: possible role in pathogenicity. J. Clin. Pathol. 42:516-522.

91. Diamond, L. A., and B. Lorber. 1984. Branhamella catarrhalis pneumonia and immunoglobulin abnormalities: a new association. Am. Rev. Respir. Dis. 129:876-878.

92. Dickinson, D. P., B. G. Loos, D. M. Dryja, and J. M. Bernstein. 1988. Restriction fragment mapping of Branhamella catarrhalis: a new tool for studying the epidemiology of this middle ear pathogen. J. Infect. Dis. 158:205-208.

93. DiGiovanni, C., T. V. Riley, G. F. Hoyne, R. Yeo, and P. Cooksey. 1987. Respiratory tract infections due to Branhamella catarrhalis: epidemiological data from Western Australia. Epidemiol. Infect. 99:445-453.

94. Dillon, J. R., M. Carballo, and M. Pauzé. 1988. Evaluation of eight methods for identification of pathogenic Neisseria species: Neisseria-Kwik, RIM-N, Gonobio-Test, Minitek, Gonochek II, GonoGen, Phadebact Monoclonal GC OMNI Test, and Syva MicroTrak Test. J. Clin. Microbiol. 26:493-497.

95. Diven, W. F., W. J. Doyle, and B. Vietmeier. 1988. Hydrolytic enzymes in otitis media pathogenesis. Ann. Otol. Rhinol. Laryngol. 97:6-9.

96. Doern, G. V., and N. M. Gantz. 1982. Isolation of Branhamella (Neisseria) catarrhalis from men with urethritis. Sex. Transm. Dis. 9:202-204.

97. Doern, G. V., and R. N. Jones. 1988. Antimicrobial susceptibility testing of Haemophilus influenzae, Branhamella catarrh alis, and Neisseria gonorrhoeae. Antimicrob. Agents Chemother. 32:1747-1753.

98. Doern, G. V., M. J. Miller, and R. E. Winn. 1981. Branhamella (Neisseria) catarrhalis systemic disease in humans. Case reports and review of the literature. Arch. Intern. Med. 141: $1690-1692$.

99. Doern, G. V., and S. A. Morse. 1980. Branhamella (Neisseria) catarrhalis: criteria for laboratory identification. J. Clin. Microbiol. 11:193-195.

100. Doern, G. V., K. G. Siebers, L. M. Hallick, and S. A. Morse. 1980. Antibiotic susceptibility of beta-lactamase-producing strains of Branhamella (Neisseria) catarrhalis. Antimicrob. Agents Chemother. 17:24-29.

101. Doern, G. V., and T. A. Tubert. 1987. Detection of $\beta$-lactamase activity among clinical isolates of Branhamella catarrhalis with six different $\beta$-lactamase assays. J. Clin. Microbiol. 25:1380-1383.

102. Doern, G. V., and T. A. Tubert. 1987. Effect of inoculum size on results of macrotube broth dilution susceptibility tests with Branhamella catarrhalis. J. Clin. Microbiol. 25:1576-1578.

103. Doern, G. V., and T. A. Tubert. 1988. In vitro activities of 39 antimicrobial agents for Branhamella catarrhalis and comparison of results with different quantitative susceptibility test methods. Antimicrob. Agents Chemother. 32:259-261.

104. Dorward, D. W., C. F. Garon, and R. C. Judd. 1989. Export 
and intercellular transfer of DNA via membrane blebs of Neisseria gonorrhoeae. J. Bacteriol. 171:2499-2505.

105. Douer, D., Y. Danziger, and J. Pinkhas. 1977. Neisseria catarrhalis endocarditis. Ann. Intern. Med. 86:116.

106. Doyle, W. J. 1989. Animal models of otitis media: other pathogens. Pediatr. Infect. Dis. J. 8(Suppl.):S45-S47.

107. Dunkin, K. T., S. Jones, and A. J. Howard. 1988. The in-vitro activity of CP-62,993 against Haemophilus influenzae, Branhamella catarrhalis, staphylococci and streptococci. J. Antimicrob. Chemother. 21:405-411.

108. Dunn, R. A., and M. H. Gordon. 1905. Clinical and bacteriological aspects of an epidemic simulating influenza. Br. Med. J. ii:421-427.

109. Durussel, C., and H. H. Siegrist. 1988. Evaluation of three commercial systems for the identification of pathogenic Neisseria and Branhamella species against the conventional method. Zentralbl. Bakteriol. Mikrobiol. Hyg. Reihe A 268: 318-324.

110. Eliasson, I. 1980. A protein antigen characteristic of Branhamella catarrhalis. Acta Pathol. Microbiol. Scand. Sect. B 88:281-286.

111. Eliasson, I., and C. Kamme. 1985. Characterization of the plasmid-mediated $\beta$-lactamase in Branhamella catarrhalis, with special reference to substrate affinity. J. Antimicrob. Chemother. 15:139-149.

112. Elser, W. J., and F. M. Huntoon. 1909. Studies on meningitis. J. Med. Res. 20:373-541.

113. Elston, H. R., H. J. Quigley, Jr., and D. M. Fitch. 1970. Meningitis due to Neisseria catarrhalis. Nebr. State Med. J. 55:369-371.

114. Ernst, T. N., and M. Philp. 1987. Bacterial tracheitis caused by Branhamella catarrhalis. Pediatr. Infect. Dis. J. 6:574.

115. Farmer, T., and C. Reading. 1982. $\beta$-Lactamases of Branhamella catarrhalis and their inhibition by clavulanic acid. Antimicrob. Agents Chemother. 21:506-508.

116. Farmer, T., and C. Reading. 1986. Inhibition of the $\beta$-lactamases of Branhamella catarrhalis by clavulanic acid and other inhibitors. Drugs 31(Suppl. 3):70-78.

117. Feder, H. M., Jr., and R. A. Garibaldi. 1984. The significance of nongonococcal, nonmeningococcal Neisseria isolates from blood cultures. Rev. Infect. Dis. 6:181-188.

118. Feigin, R. D., V. San Joaquin, and J. N. Middelkamp. 1969. Pupura fulminans associated with Neisseria catarrhalis septicema and meningitis. Pediatrics 44:120-123.

119. Fernández-Roblas, R., M. J. Arriero, J. L. Rodriguez-Tudela, and $\mathbf{F}$. Soriano. 1988. In-vitro activity of amoxycillin/clavulanic acid and five other oral antibiotics against clinical isolates of Haemophilus influenzae and Branhamella catarrhalis. J. Antimicrob. Chemother. 22:867-872.

120. Forsgren, A., A. Penta, S. F. Schlossman, and T. F. Tedder. 1988. Branhamella catarrhalis activates human B lymphocytes following interactions with surface IgD and class 1 major histocompatibility complex antigens. Cell. Immunol. 112:7888.

121. Forsgren, A., and M. Walder. 1984. Activity of common antibiotics against Branhamella catarrhalis, Haemophilus influenzae, pneumococci, group A streptococci and Staphylococcus aureus in 1983. Acta Oto Laryngol. Suppl. 407:43-49.

122. Fox, R. H., and D. E. McClain. 1974. Evaluation of the taxonomic relationship of Micrococcus cryophilus, Branhamella catarrhalis, and neisseriae by comparative polyacrylamide gel electrophoresis of soluble proteins. Int. J. Syst. Bacteriol. 24:172-176.

123. Fox, R. H., and D. E. McClain. 1975. Enzyme electrophoretograms in the analysis of taxon relatedness of Micrococcus cryophilus, Branhamella catarrhalis and atypical neisserias. J. Gen. Microbiol. 86:210-216.

124. Frasch, C. E., W. D. Zollinger, and J. T. Poolman. 1985. Proposed scheme for identification of serotypes of Neisseria meningitidis, p. 519-524. In G. K. Schoolnik, G. F. Brooks, S. Falkow, C. E. Frasch, J. S. Knapp, J. A. McCutchan, and S. A. Morse (ed.), The pathogenic neisseriae. American Society for Microbiology, Washington, D.C.
125. Frosch, P., and W. Kolle. 1896. Die Mikrokokken, p. 154-155. In C. Flügge (ed.), Die Mikroorganismen, vol. 2. Verlag von Vogel, Leipzig.

126. Garland, J. 1923. A case of meningitis due to Micrococcus catarrhalis. Am. J. Dis. Child. 26:600-602.

127. Geckler, R. W., D. H. Gremillion, C. K. McAllister, and C. Ellenbogen. 1977. Microscopic and bacteriological comparison of paired sputa and transtracheal aspirates. J. Clin. Microbiol. 6:396-399.

128. Georgopapadakou, N. H., and R. B. Sykes. 1983. Bacterial enzymes interacting with $\beta$-lactam antibiotics, p. 1-77. In A. L. Demain and N. A. Soloman (ed.), Antibiotics containing the beta-lactam structure. part II. Springer-Verlag, Berlin.

129. Giebink, G. S., S. K. Juhn, M. L. Weber, and C. T. Le. 1982. The bacteriology and cytology of chronic otitis media with effusion. Pediatr. Infect. Dis. 1:98-103.

130. Gordon, J. E. 1921. The Gram-negative cocci in "colds" and influenza. J. Infect. Dis. 29:462-494.

131. Gotoh, N., S. Tanaka, and T. Nishino. 1989. Supersusceptibility to hydrophobic antimicrobial agents and cell surface hydrophobicity in Branhamella catarrhalis. FEMS Microbiol. Lett. 59:211-214.

132. Gray, L. D., R. E. Van Scoy, J. P. Anhalt, and P. K. W. Yu. 1989. Wound infection caused by Branhamella catarrhalis. J. Clin. Microbiol. 27:818-820.

133. Griffiss, J. M., H. Schneider, R. E. Mandrell, R. Yamasaki, G. A. Jarvis, J. J. Kim, B. W. Gibson, R. Hamadeh, and M. A. Apicella. 1988. Lipooligosaccharides: the principal glycolipids of the neisserial outer membrane. Rev. Infect. Dis. 10(Suppl. 2):S287-S298

134. Griffiths, L. R., S. Purohit, and P. A. Leonard. 1986. Increase in bronchopulmonary infection due to Branhamella catarrhalis. Br. Med. J. 292:1461.

135. Grönroos, J. A., A. E. Kortekangas, L. Ojala, and M. Vuori. 1964. The aetiology of acute middle ear infection. Acta Otolaryngol. 58:149-158.

136. Guibourdenche, M., M. Y. Popoff, and J. Y. Riou. 1986. Deoxyribonucleic acid relatedness among Neisseria gonorrhoeae, $N$. meningitidis, $N$. lactamica, $N$. cinerea, and "Neisseria polysaccharea." Ann. Inst. Pasteur (Paris) 137B:177185.

137. Gunnarsson, M., and L. Grip. 1982. Atypical croup and Branhamella catarrhalis. Lancet ii:156.

138. Guthrie, R., K. Bakenhaster, R. Nelson, and R. Woskobnick. 1988. Branhamella catarrhalis sepsis: a case report and review of the literature. J. Infect. Dis. 158:907-908.

139. Haddad, J., A. Lefaou, U. Simeoni, and J. Messer. 1985. Branhamella catarrhalis en pathologie infectieuse pulmonaire neonatale. Pediatrie 40:553-556.

140. Hager, H., A. Verghese, S. Alvarez, and S. L. Berk. 1987. Branhamella catarrhalis respiratory infections. Rev. Infect. Dis. 9:1140-1149.

141. Halsted, C., M. L. Lepow, N. Balassanian, J. Emmerich, and E. Wolinsky. 1968. Otitis media: clinical observations, microbiology, and evaluation of therapy. Amer. J. Dis. Child. 115:542551 .

142. Hehre, E. J., and D. M. Hamilton. 1948. The conversion of sucrose to a polysaccharide of the starch-glycogen class by Neisseria from the pharynx. J. Bacteriol. 55:197-208.

143. Hellio, R., M. Guibourdenche, E. Collatz, and J. Y. Riou. 1988. The envelope structure of Branhamella catarrhalis as studied by transmission electron microscopy. Ann. Inst. Pasteur (Paris) 139:515-525.

144. Henny, F. C., C. J. J. Mulder, A. S. Lampe, and J. W. M. van der Meer. 1984. Branhamella catarrhalis septicemia in a granulocytopenic patient. Infection 12:208-209.

145. Henriksen, S. D. 1976. Moraxella, Neisseria, Branhamella, and Acinetobacter. Annu. Rev. Microbiol. 30:63-83.

146. Henriksen, S. D., and K. Bøvre. 1968. The taxonomy of the genera Moraxella and Neisseria. J. Gen. Microbiol. 51:387392.

147. Hoke, C., and N. A. Vedros. 1982. Taxonomy of the neisseriae: fatty acid analysis, aminopeptidase activity, and pigment ex- 
traction. Int. J. Syst. Bacteriol. 32:51-56.

148. Hoke, C., and N. A. Vedros. 1982. Taxonomy of the neisseriae: deoxyribonucleic acid base composition, interspecific transformation, and deoxyribonucleic acid hybridization. Int. J. Syst. Bacteriol. 32:57-66.

149. Holland, D. F. 1920. Generic index of the commoner forms of bacteria. J. Bacteriol. 5:215-229.

150. Hosmer, M. E., M. A. Cohenford, and P. D. Ellner. 1986. Preliminary evaluation of a rapid colorimetric method for identification of pathogenic Neisseria. J. Clin. Microbiol. 24: 141-142.

151. Izraeli, S., B. Flasterstein, R. Shamir, A. Rachmel, M. Nitzan, M. Drucker, and Z. Samra. 1989. Branhamella catarrhalis as a cause of suppurative arthritis. Pediatr. Infect. Dis. J. 8:256257.

152. Jackson, P., M. J. Thornley, and R. J. Thompson. 1984. A study by high-resolution two-dimensional polyacrylamide gel electrophoresis of relationships between Neisseria gonorrhoeae and other bacteria. J. Gen. Microbiol. 130:3189-3201.

153. Jacobson, S. H., and A. Björklind. 1989. Symptomatic bacteriuria caused by Branhamella catarrhalis. J. Infect. 18:192193.

154. Janda, W. M., and P. Ruther. 1989. B.CAT CONFIRM, a rapid test for confirmation of Branhamella catarrhalis. J. Clin. Microbiol. 27:1130-1131.

155. Janda, W. M., M. G. Ulanday, M. Bohnhoff, and L. J. LeBeau. 1985. Evaluation of the RIM-N, Gonochek II, and Phadebact systems for the identification of pathogenic Neisseria spp. and Branhamella catarrhalis. J. Clin. Microbiol. 21:734-737.

156. Janda, W. M., K. L. Zigler, and J. J. Bradna. 1987. API QuadFERM + with rapid DNase for identification of Neisseria spp. and Branhamella catarrhalis. J. Clin. Microbiol. 25:203206.

157. Jantzen, E. 1984. Analysis of cellular components in bacterial classification and diagnosis, p. 257-302. In G. Odham, L. Larsson, and P.-A. Mårdh (ed.), Gas chromatography, mass spectrometry: applications in microbiology. Plenum Publishing Corp., New York.

158. Johnson, A. P. 1983. The pathogenic potential of commensal species of Neisseria. J. Clin. Pathol. 36:213-223.

159. Johnson, K. G., I. J. McDonald, and M. B. Perry. 1976. Studies on the cellular and free lipopolysaccharides from Branhamella catarrhalis. Can. J. Microbiol. 22:460-467.

160. Johnson, M. A., W. L. Drew, and M. Roberts. 1981. Branhamella (Neisseria) catarrhalis - a lower respiratory tract pathogen? J. Clin. Microbiol. 13:1066-1069.

161. Johnsson, J., and J.-E. Brorson. 1983. Influence of $\beta$-lactamase-producing strains of Branhamella catarrhalis and Haemophilus influenzae on certain $\beta$-lactam antibiotics. J. Antimicrob. Chemother. 12:269-271.

162. Jones, R. N., and H. M. Sommers. 1986. Identification and antimicrobial susceptibility testing of Branhamella catarrhalis in United States laboratories, 1983-1985. Drugs 31(Suppl. 3):34-37.

163. Jousimies-Somer, H. R., S. Savolainen, and J. S. Ylikoski. 1989. Comparison of the nasal bacterial floras in two groups of healthy subjects and in patients with acute maxillary sinusitis. J. Clin. Microbiol. 27:2736-2743.

164. Juni, E., G. A. Heym, and M. Avery. 1986. Defined medium for Moraxella (Branhamella) catarrhalis. Appl. Environ. Microbiol. 52:546-551.

165. Kallings, I. 1986. Sensitivity of Branhamella catarrhalis to oral antibiotics. Drugs 31(Suppl. 3):17-22.

166. Kamme, C. 1970. Evaluation of the in vitro sensitivity of Neisseria catarrhalis to antibiotics with respect to acute otitis media. Scand. J. Infect. Dis. 2:117-120.

167. Kamme, C., I. Eliasson, B. K. Knutson, and M. Vang. 1986. Plasmid-mediated $\beta$-lactamase in Branhamella catarrhalis. Drugs 31(Suppl. 3):55-63.

168. Kamme, C., K. Lundgren, and P.-A. Märdh. 1971. The aetiology of acute otitis media in children. Scand. J. Infect. Dis. 3:217-223.

169. Kamme, C., M. Vang, and S. Ståhl. 1983. Transfer of $\beta$-lacta- mase production in Branhamella catarrhalis. Scand. J. Infect. Dis. 15:225-226.

170. Kamme, C., M. Vang, and S. Ståhl. 1984. Intrageneric and intergeneric transfer of Branhamella catarrhalis $\beta$-lactamase production. Scand. J. Infect. Dis. 16:153-155.

171. Karnad, A., S. Alvarez, and S. L. Berk. 1986. Branhamella catarrhalis pneumonia in patients with immunoglobulin abnormalities. South. Med. J. 79:1360-1362.

172. Kawakami, Y., K. Segawa, and M. Kanai. 1983. A case of acute catarrhal conjunctivitis due to Branhamella catarrhalis. Microbiol. Immunol. 27:641-643.

173. Keren, G., B. Bogokowsky, and Z. Barzilay. 1989. Branhamella catarrhalis pneumonia in non-immunocompromised pediatric patients: report of three cases and review of the literature. $\mathbf{J}$. Med. 20:65-71.

174. Kingsbury, D. T. 1967. Deoxyribonucleic acid homologies among species of the genus Neisseria. J. Bacteriol. 94:870-874.

175. Kingsbury, D. T. 1969 . Estimate of the genome size of various organisms. J. Bacteriol. 98:1400-1401.

176. Kingsbury, D. T., G. R. Fanning, K. E. Johnson, and D. J. Brenner. 1969. Thermal stability of interspecies Neisseria DNA duplexes. J. Gen. Microbiol. 55:201-208.

177. Knapp, J. S. 1988. Historical perspectives and identification of Neisseria and related species. Clin. Microbiol. Rev. 1:415-431.

178. Knapp, J. S., and K. K. Holmes. 1983. Modified oxidationfermentation medium for detection of acid production from carbohydrates by Neisseria spp. and Branhamella catarrhalis. J. Clin. Microbiol. 18:56-62.

179. Knapp, J. S., and E. W. Hook III. 1988. Prevalence and persistence of Neisseria cinerea and other Neisseria spp. in adults. J. Clin. Microbiol. 26:896-900.

180. Knapp, J. S., P. A. Totten, M. H. Mulks, and B. H. Minshew. 1984. Characterization of Neisseria cinerea, a nonpathogenic species isolated on Martin-Lewis medium selective for pathogenic Neisseria spp. J. Clin. Microbiol. 19:63-67.

181. Koelbl, J. A., and B. W. Catlin. 1986. Vancomycin hypersusceptibility in Neisseria gonorrhoeae isolated from patients involves diverse mutations. Antimicrob. Agents Chemother. 29:687-695.

182. Koomey, J. M., and S. Falkow. 1984. Nucleotide sequence homology between the immunoglobulin A1 protease genes of Neisseria gonorrhoeae, Neisseria meningitidis, and Haemophilus influenzae. Infect. Immun. 43:101-107.

183. Kostiala, A. A. I., and T. Honkanen. 1989. Branhamella catarrhalis as a cause of acute purulent pericarditis. J. Infect. 19:291-292.

184. Kovatch, A. L., E. R. Wald, and R. H. Michaels. 1983. $\beta$-Lactamase-producing Branhamella catarrhalis causing otitis media in children. J. Pediatr. 102:261-264.

185. Lairscey, R. C., and M. T. Kelly. 1985. Evaluation of a one-hour test for identification of Neisseria species. J. Clin. Microbiol. 22:238-240.

186. LaMacchia, E. H., and M. J. Pelczar, Jr. 1966. Analyses of deoxyribonucleic acid of Neisseria caviae and other Neisseria. J. Bacteriol. 91:514-516.

187. Lambert, M. A., D. G. Hollis, C. W. Moss, R. E. Weaver, and M. L. Thomas. 1971. Cellular fatty acids of nonpathogenic Neisseria. Can. J. Microbiol. 17:1491-1502.

188. Lee, W.-S., T. Fordham, and J. Alban. 1981. Otitis media caused by beta-lactamase-producing Branhamella (Neisseria) catarrhalis. J. Clin. Microbiol. 13:222-223.

189. Leinonen, M., J. Luotonen, E. Herva, K. Valkonen, and P. H. Mäkelä. 1981. Preliminary serologic evidence for a pathogenic role of Branhamella catarrhalis. J. Infect. Dis. 144:570-574.

190. Lewis, V. J., R. E. Weaver, and D. G. Hollis. 1968. Fatty acid composition of Neisseria species as determined by gas chromatography. J. Bacteriol. 96:1-5.

191. Livermore, D. M. 1988 . Permeation of $\beta$-lactam antibiotics into Escherichia coli, Pseudomonas aeruginosa, and other gramnegative bacteria. Rev. Infect. Dis. 10:691-698.

192. Louie, M. H., E. L. Gabay, G. E. Mathisen, and S. M. Finegold. 1983. Branhamella catarrhalis pneumonia. West. J. Med. 138:47-49. 
193. Luman, I., R. W. Wilson, R. J. Wallace, Jr., and D. R. Nash. 1986. Disk diffusion susceptibility of Branhamella catarrhalis and relationship of $\beta$-lactam zone size to $\beta$-lactamase production. Antimicrob. Agents Chemother. 30:774-776.

194. Lundgren, K., and L. Ingvarsson. 1986. Acute otitis media in Sweden: role of Branhamella catarrhalis and the rationale for choice of antimicrobial therapy. Drugs 31(Suppl. 3):125-131.

195. Mackowiak, P. A. 1982. The normal microbial flora. N. Engl. J. Med. 307:83-93.

196. Macsai, M. S., D. S. Hillman, and J. B. Robin. 1988. Branhamella keratitis resistant to penicillin and cephalosporins. Arch. Ophthalmol. 106:1506-1507.

197. Malkamäki, M., E. Honkanen, M. Leinonen, and P. H. Mäkelä. 1983. Branhamella catarrhalis as a cause of bacteremic pneumonia. Scand. J. Infect. Dis. 15:125-126.

198. Malmvall, B.-E., J.-E. Brorsson, and J. Johnsson. 1977. In vitro sensitivity to penicillin $\mathrm{V}$ and $\beta$-lactamase production of $\mathrm{Bra}$ nhamella catarrhalis. J. Antimicrob. Chemother. 3:374-375.

199. Mannheim, W., and H. Bürger. 1967. The taxonomic significance of some bacterial hydrolase reactions-preliminary results, p. 199-202. In Reports from the conference on the taxonomy of bacteria held in the Czechoslovak Collection of Microorganisms, September 1967, Brno. Spisy, University J. E. Purkyne Publications, Brno, Czechoslovakia.

200. Mannion, P. T. 1987. Sputum microbiology in a district general hospital: the role of Branhamella catarrhalis. Br. J. Dis. Chest 81:391-396.

201. Mannion, P. T. 1989. Tributyrin hydrolysis for identifying Branhamella catarrhalis. J. Clin. Pathol. 42:115.

202. Marmur, J., and P. Doty. 1962. Determination of the base composition of deoxyribonucleic acid from its thermal denaturation temperature. J. Mol. Biol. 5:109-118.

203. Mbaki, N., N. Rikitomi, T. Nagatake, and K. Matsumoto. 1987. Correlation between Branhamella catarrhalis adherence to oropharyngeal cells and seasonal incidence of lower respiratory tract infections. Tohoku J. Exp. Med. 153:111-121.

204. McGee, Z. A., D. S. Stephens, L. H. Hoffman, W. F. Schlech, III, and R. G. Horn. 1983. Mechanisms of mucosal invasion by pathogenic Neisseria. Rev. Infect. Dis. 5(Suppl. 4):S708-S714.

205. McLeod, D. T., F. Ahmad, and M. A. Calder. 1985. Infection and Branhamella catarrhalis. Biomed. Pharmacother. 39:170 173.

206. McLeod, D. T., F. Ahmad, S. Capewell, M. J. Croughan, M. A. Calder, and A. Seaton. 1986. Increase in bronchopulmonary infection due to Branhamella catarrhalis. Br. Med. J. 292: 1103-1105.

207. McLeod, D. T., F. Ahmad, J. T. Power, M. A. Calder, and A. Seaton. 1983. Bronchopulmonary infection due to Branhamella catarrhalis. Br. Med. J. 287:1446-1447.

208. McLeod, D. T., M. J. Croughan, F. Ahmad, R. P. Brettle, and M. A. Calder. 1986. Lack of immunoglobulin A1 protease production by Branhamella catarrhalis. Infect. Immun. 52: $631-632$.

209. McNeely, D. J., C. S. Kitchens, and R. M. Kluge. 1976. Fatal Neisseria (Branhamella) catarrhalis pneumonia in an immunodeficient host. Am. Rev. Respir. Dis. 114:399-402.

210. Mölstad, S., I. Eliasson, B. Hovelius, C. Kamme, and C. Schalén. 1988. Beta-lactamase production in the upper respiratory tract flora in relation to antibiotic consumption: a study in children attending day nurseries. Scand. J. Infect. Dis. 20:329334.

211. Monroe, P. W., H. G. Muchmore, F. G. Felton, and J. K. Pirtle. 1969. Quantitation of microorganisms in sputum. Appl. Microbiol. 18:214-220.

212. Morello, J. A., W. M. Janda, and M. Bohnhoff. 1985. Neisseria and Branhamella, p. 176-192. In E. H. Lennette, A. Balows, W. J. Hausler, Jr., and H. J. Shadomy (ed.). Manual of clinical microbiology, 4th ed. American Society for Microbiology, Washington, D.C.

213. Morse, S. A., P. G. Lysko, L. McFarland, J. S. Knapp, E. Sandstrom, C. Critchlow, and K. K. Holmes. 1982. Gonococcal strains from homosexual men have outer membranes with reduced permeability to hydrophobic molecules. In- fect. Immun. 37:432-438.

214. Murphey-Corb, M., M. Nolan-Willard, and R. S. Daum. 1984. Integration of plasmid DNA coding for $\beta$-lactamase production in the Haemophilus influenzae chromosome. J. Bacteriol. 160:815-817.

215. Murphy, T. F. 1989. The surface of Branhamella catarrhalis: a systematic approach to the surface antigens of an emerging pathogen. Pediatr. Infect. Dis. J. 8(Suppl.):S75-S77.

216. Murphy, T. F., and L. C. Bartos. 1989. Surface-exposed and antigenically conserved determinants of outer membrane proteins of Branhamella catarrhalis. Infect. Immun. 57:29382941.

217. Murphy, T. F., and M. R. Loeb. 1989. Isolation of the outer membrane of Branhamella catarrhalis. Microb. Pathogen. 6:159-174

218. Nagatake, T. 1985. Clinical significance of respiratory infection caused by Branhamella catarrhalis with special reference to $\beta$-lactamase producing strains. Tohoku J. Exp. Med. 147:1-13.

219. Naqvi, S. H., B. Kilpatrick, and J. Bouhasin. 1988. Branhamella catarrhalis meningitis following otolaryngologic surgery. APMIS Suppl. 3:74-75.

220. Nash, D. R., R. J. Wallace, Jr., V. A. Steingrube, and P. A. Shurin. 1986. Isoelectric focusing of $\beta$-lactamases from sputum and middle ear isolates of Branhamella catarrhalis recovered in the United States. Drugs 31(Suppl. 3):48-54.

221. Nicotra, B., M. Rivera, J. I. Luman, and R. J. Wallace, Jr. 1986. Branhamella catarrhalis as a lower respiratory tract pathogen in patients with chronic lung disease. Arch. Intern. Med. 146:890-893.

222. Nikaido, H. 1989. Outer membrane barrier as a mechanism of antimicrobial resistance. Antimicrob. Agents Chemother. 33: 1831-1836

223. Nikaido, H., and M. Vaara. 1985. Molecular basis of bacterial outer membrane permeability. Microbiol. Rev. 49:1-32.

224. Ninane, G., J. Joly, and M. Kraytman. 1978. Bronchopulmonary infection due to Branhamella catarrhalis: 11 cases assessed by transtracheal puncture. Br. Med. J. 1:276-278.

225. Nord, C. E. 1988. Efficacy of penicillin treatment in purulent maxillary sinusitis: a European multicenter trial. Infection 16:209-214.

226. Norrod, E. P., L. Bartenstein, and S. A. Morse. 1981. Comparison of the superoxide dismutases of Branhamella catarrhalis, Neisseria ovis, and Neisseria caviae. Int. J. Syst. Bacteriol. 31:392-395.

227. Novotny, P., J. A. Short, and P. D. Walker. 1975. An electronmicroscope study of naturally occurring and cultured cells of Neisseria gonorrhoeae. J. Med. Microbiol. 8:413-427.

228. Ohlsson, A., and T. Bailey. 1985. Neonatal pneumonia caused by Branhamella catarrhalis. Scand. J. Infect. Dis. 17:225-228.

229. Patterson, J. E., T. F. Patterson, P. Farrel, W. J. Hierholzer, Jr., and M. J. Zervos. 1989. Evaluation of restriction endonuclease analysis as an epidemiologic typing system for $\mathrm{Bra}$ nhamella catarrhalis. J. Clin. Microbiol. 27:944-946.

230. Patterson, T. F., J. E. Patterson, B. L. Masecar, G. E. Barden, W. J. Hierholzer, Jr., and M. J. Zervos. 1988. A noscomial outbreak of Branhamella catarrhalis confirmed by restriction endonuclease analysis. J. Infect. Dis. 157:996-1001.

231. Percival, A., J. E. Corkill, J. Rowlands, and R. B. Sykes. 1977. Pathogenicity of and B-lactamase production by Branhamella (Neisseria) catarrhalis. Lancet ii: 1175.

232. Pfister, L. E., M. V. Gallagher, T. G. Potterfield, and D. W. Brown. 1965. Neisseria catarrhalis bacteremia with meningitis. J. Am. Med. Assoc. 193:399-401.

233. Philip, A., and G. C. Garton. 1985. Comparative evaluation of five commercial systems for the rapid identification of pathogenic Neisseria species. J. Clin. Microbiol. 22:101-104.

234. Philippon, A., J. Y. Riou, M. Guibourdenche, and F. Sotolongo. 1986. Detection, distribution and inhibition of Branhamella catarrhalis $\beta$-lactamases. Drugs 31(Suppl. 3):64-69.

235. Picard, B., P. Goullet, E. Denamur, and G. Suermondt. 1989. Esterase electrophoresis: a molecular tool for studying the epidemiology of Branhamella catarrhalis nosocomial infection. Epidemiol. Infect. 103:547-554. 
236. Pike, E. B., J. H. Freer, G. H. G. Davis, and K. A. Bisset. 1962 The taxonomy of micrococci and neisseriae of oral origin. Arch. Oral. Biol. 7:715-726.

237. Pintado, C., C. Salvador, R. Rotger, and C. Nombela. 1985. Multiresistance plasmid from commensal Neisseria species. Antimicrob. Agents Chemother. 27:120-124.

238. Piotrowski, H. D., and U. Berger. 1973. Weitere Untersuchungen über die lipolytische Aktivität der Neisserien. Zentralbl. Bakteriol. Parasitenkd. Infektionskr. Hyg. Abt. 1 Orig. Reihe A 225:466-470.

239. Pittman, M. 1986. Sara Elizabeth Branham (Matthews). A biographical sketch. Drugs 31(Suppl. 3):ix-xi.

240. Platt, D. J., and J. J. S. Snell. 1976. Isolation of oxidasepositive Gram-negative cocci not belonging to the genus Neisseria from the urogenital tract. J. Clin. Pathol. 29:537-542.

241. Pollard, J. A., R. J. Wallace, Jr., D. R. Nash, J. I. Luman, and R. W. Wilson. 1986. Incidence of Branhamella catarrhalis in the sputa of patients with chronic lung disease. Drugs 31(Suppl. 3):103-108.

242. Pollock, A. A., and R. S. Holzman. 1976. Neisseria catarrhalis endocarditis. Ann. Intern. Med. 85:206-207.

243. Prellner, K. 1980. Bacteria associated with acute otitis media have high $\mathrm{Clq}$ binding capacity. Acta Pathol. Microbiol. Scand. Sect. C 88:187-190.

244. Renneberg, J., and M. Walder. 1989. The role of $\beta$-lactamase in mixed infections in mice in relation to treatment with ampicillin. J. Infect. Dis. 160:337-341.

245. Reyn, A. 1974. Family I. Neisseriaceae Prévot 1933, p. $427-$ 433, 442-443. In R. E. Buchanan and N. E. Gibbons (ed.), Bergey's manual of determinative bacteriology, 8th ed. The Williams \& Wilkins Co., Baltimore

246. Rice, P. A. 1989. Molecular basis for serum resistance in Neisseria gonorrhoeae. Clin. Microbiol. Rev. 2(Suppl.):S112S117.

247. Richards, J. 1988. Evaluation of a rapid method for identifying Branhamella catarrhalis. J. Clin. Pathol. 41:462-464.

248. Righter, J., and G. Nicol. 1983. Branhamella catarrhalis conjunctivitis. Can. Med. Assoc. J. 128:955-956.

249. Rikitomi, N., N. Mbaki, T. Nagatake, and K. Matsumoto. 1986. Adherence of Branhamella catarrhalis to human pharyngeal cells: relationship between adherence in vitro and chronic respiratory infections. Nippon Kyobu Shikkan Gakkai Zasshi 24:633-638. (In Japanese.)

250. Riley, T. V. 1987. A note on hydrolysis of tributyrin by Branhamella and Neisseria. J. Appl. Bacteriol. 62:539-542.

251. Riley, T. V., and C. DiGiovanni. 1989. Susceptibility of Branhamella catarrhalis to tetracyclines. J. Antimicrob. Chemother. 23:802-804.

252. Riley, T. V., C. DiGiovanni, and G. F. Hoyne. 1987. Susceptibility of Branhamella catarrhalis to sulphamethoxazole and trimethoprim. J. Antimicrob. Chemother. 19:39-43.

253. Riley, T. V., and M. L. Taylor. 1989. A note on susceptibility of Branhamella catarrhalis to heavy metals. J. Appl. Bacteriol. 67:185-189.

254. Riou, J. Y., J. Buissière, M. Guibourdenche, G. Brault, and J. P. Carlier. 1981. Hydrolyse de la tributyrine pas les Neisseria et les Branhamella. Ann. Microbiol. (Paris) 132A:159169.

255. Riou, J. Y., J. Buissière, C. Richard, and M. Guibourdenche. 1982. Intèrêt de la recherche de la $\gamma$-glutamyl-transférase chez les Neisseriaceae. Ann. Microbiol. (Paris) 133A:387-392.

256. Riou, J. Y., and M. Guibourdenche. 1977. Diagnostic bactériologique des espèces des genres Neisseria et Branhamella. Ann. Biol. Clin. 35:73-87.

257. Riou, J. Y., and M. Guibourdenche. 1986. Branhamella catarrhalis: new methods of bacterial diagnosis. Drugs 31(Suppl. $3): 1-6$.

258. Riou, J.-Y., and M. Guibourdenche. 1987. Neisseria polysaccharea sp. nov. Int. J. Syst. Bacteriol. 37:163-165.

259. Robinson, A., P. C. Johnson, and S. B. Griffith. 1987. Clinical interpretation of beta-lactamase-producing strains of $\mathrm{Bra}$ nhamella catarrhalis in sputum Gram's stain and culture. Am. J. Clin. Pathol. 87:498-503.
260. Romberger, J. A., E. R. Wald, and P. F. Wright. 1987. Branhamella catarrhalis conjunctivitis. South. Med. J. 80:926928.

261. Rossau, R., A. Van Landschoot, W. Mannheim, and J. De Ley. 1986. Inter- and intrageneric similarities of ribosomal ribonucleic acid cistrons of the Neisseriaceae. Int. J. Syst. Bacteriol. 36:323-332.

262. Roth, R. M., R. A. Gleckman, and D. M. Hibert. 1984. Branhamella catarrhalis: an unappreciated pulmonary pathogen. Am. Fam. Physician 30:169-173.

263. Russell, R. R. B., K. G. Johnson, and I. J. McDonald. 1978. Immunological relationships of some non-pathogenic Neisseria. Can. J. Microbiol. 24:189-191.

264. Russell, R. R. B., and I. J. McDonald. 1976. Comparison of the cell envelope proteins of Micrococcus cryophilus with those of Neisseria and Branhamella species. Can. J. Microbiol. 22:309312 .

265. Ruuskanen, O., M. Arola, A. Putto-Laurila, J. Mertsola, O. Meurman, M. K. Viljanen, and P. Halonen. 1989. Acute otitis media and respiratory virus infections. Pediatr. Infect. Dis. J. 8:94-99.

266. Saginur, R., B. Clecner, J. Portnoy, and J. Mendelson. 1982. Superoxol (catalase) test for identification of Neisseria gonorrhoeae. J. Clin. Microbiol. 15:475-477.

267. Saito, A., K. Yamaguchi, Y. Shigeno, S. Kohno, H. Shigeno, N. Kusano, Y. Dotsu, and K. Hara. 1986. Clinical and bacteriological evaluation of Branhamella catarrhalis in respiratory infections. Drugs 31(Suppl. 3):87-92.

268. Saito, H., E. J. Anaissie, N. Khardori, and G. P. Bodey. 1988. Branhamella catarrhalis septicemia in patients with leukemia. Cancer 61:2315-2317.

269. Schønheyder, H., and T. Ejlertsen. 1989. Branhamella catarrhalis in lower respiratory tract secretions in adults. Eur. J. Clin. Microbiol. Infect. Dis. 8:299-300.

270. Schreiner, A., G. Bjerkestrand, A. Digranes, F. J. Halvorsen, and T. M. Kommedal. 1978. Bacteriological findings in the transtracheal aspirate from patients with acute exacerbation of chronic bronchitis. Infection 6:54-56.

271. Schryvers, A. B., and B. C. Lee. 1989. Comparative analysis of the transferrin and lactoferrin binding proteins in the family Neisseriaceae. Can. J. Microbiol. 35:409-415.

272. Schwartz, R., W. J. Rodriguez, R. Mann, W. Kahn, and S. Ross. 1979. The nasopharyngeal culture in acute otitis media: a reappraisal of its usefulness. J. Am. Med. Assoc. 421:2170 2173.

273. Shaw, J. H., and S. Falkow. 1988. Model for invasion of human tissue culture cells by Neisseria gonorrhoeae. Infect. Immun. 56:1625-1632.

274. Shurin, P. A., C. D. Marchant, C. H. Kim, G. F. Van Hare, C. E. Johnson, M. A. Tutihasi, and L. J. Knapp. 1983. Emergence of beta-lactamase-producing strains of Branhamella catarrhalis as important agents of acute otitis media. Pediatr. Infect. Dis. J. 2:34-38.

275. Simpson, I. N., and P. B. Harper. 1981. Isoelectric focusing of B-lactamases. J. Antimicrob. Chemother. 7:307.

276. Simpson, I. N., and S. J. Plested. 1983. The origin and properties of $\beta$-lactamase satellite bands seen in isoelectric focusing. J. Antimicrob. Chemother. 12:127-131.

277. Slevin, N. J., J. Aitken, and P. E. Thornley. 1984. Clinical and microbiological features of Branhamella catarrhalis bronchopulmonary infections. Lancet i:782-783.

278. Smith, G. L. 1987. Branhamella catarrhalis infection imitating gonorrhea in a man. N. Engl. J. Med. 316:1277.

279. Smith, J. M. B., and B. M. Lockwood. 1986. A 2-year survey of Branhamella catarrhalis in a general hospital. J. Hosp. Infect. 7:277-283.

280. Sneath, P. H. A. 1984. Bacterial nomenclature, p. 19-23. In N. R. Krieg and J. G. Holt (ed.), Bergey's manual of systematic bacteriology, vol. 1. The Williams \& Wilkins Co., Baltimore.

281. Soriano, F., M. Jiménez-Arriero, and R. Fernández-Roblas. 1987. The influence of culture medium on the comparative in-vitro activity of amoxycillin and amoxycillin/clavulanic acid 
against Branhamella catarrhalis. J. Antimicrob. Chemother. 20:285-286.

282. Soto-Hernandez, J. L., S. Holtsclaw-Berk, L. M. Harvill, and S. L. Berk. 1989. Phenotypic characteristics of Branhamella catarrhalis strains. J. Clin. Microbiol. 27:903-908.

283. Soto-Hernandez, J. L., D. Nunley, S. Holtsclaw-Berk, and S. L. Berk. 1988. Selective medium with DNase test agar and a modified toluidine blue $\mathrm{O}$ technique for primary isolation of Branhamella catarrhalis in sputum. J. Clin. Microbiol. 26:405408.

284. Spark, R. P., P. W. Dahlberg, and J. W. LaBelle. 1979. Pseudogonococcal ophthalmia neonatorum: Branhamella (Neisseria) catarrhalis conjunctivitis. Am. J. Clin. Pathol. 72:471-473.

285. Sparling, P. F. 1983. Bacterial virulence and pathogenesis: an overview. Rev. Infect. Dis. 5(Suppl. 4):S637-S646.

286. Spratt, B. G., and K. D. Cromie. 1988. Penicillin-binding proteins of gram-negative bacteria. Rev. Infect. Dis. 10:699 711.

287. Srinivasan, G., M. J. Raff, W. C. Templeton, S. J. Givens, R. C. Graves, and J. C. Melo. 1981. Branhamella catarrhalis pneumonia. Report of two cases and review of the literature. Am. Rev. Respir. Dis. 123:553-555.

288. Stackebrandt, E., R. G. E. Murray, and H. G. Trüper. 1988. Proteobacteria classis nov., a name for the phylogenetic taxon that includes the "purple bacteria and their relatives." Int. J. Syst. Bacteriol. 38:321-325.

289. Staneck, J. L. 1985. Screening tests and "rapid" identification: is anybody out there listening? Diagn. Microbiol. Infect. Dis. 3(Suppl.):51S-57S.

290. Stenfors, L.-E., and S. Räisänen. 1988. Quantification of bacteria in middle ear effusions. Acta Oto Laryngol. 106:435-440.

291. Stenfors, L.-E., and S. Räisänen. 1989. How long do middle ear pathogens survive in mucoid effusion material? Acta Oto Laryngol. 107:244-248.

292. Stephens, D. S. 1989. Gonococcal and meningococcal pathogenesis as defined by human cell, cell culture, and organ culture assays. Clin. Microbiol. Rev. 2(Suppl.):S104-S111.

293. Stirland, R. M., J. A. Tooth, and J. A. Meigh. 1984. Acute bacterial conjunctivitis and maltose negative meningococci. J. Clin. Pathol. 37:1416.

294. Stobberingh, E. E., B. I. Davies, and C. P. A. van Boven. 1984. Branhamella catarrhalis: antibiotic sensitivities and $\beta$-lactamases. J. Antimicrob. Chemother. 13:55-64.

295. Stobberingh, E. E., H. J. van Eck, A. W. Houben, and C. P. A. van Boven. 1986. Analysis of the relationship between ampicillin resistance and $\beta$-lactamase production in Branhamella catarrhalis. Drugs 31(Suppl. 3):23-27.

296. Stobberingh, E. E., M. Wunderink, M. Philips, and A. Houben. 1987. Branhamella catarrhalis $\beta$-lactamase production and sensitivity to oral antibiotics, including new cephalosporins. J. Antimicrob. Chemother. 20:765-766.

297. Stull, T. L., and E. J. Stanford. 1986. Pseudogonococcal ophthalmia neonatorum caused by Branhamella catarrhalis. Pediatr. Infect. Dis. 5:104-105.

298. Sugimoto, C., E. Miyagawa, M. Nakazawa, K. Mitani, and Y. Isayama. 1983. Cellular fatty acid composition comparisons of Haemophilus equigenitalis and Moraxella species. Int. J. Syst. Bacteriol. 33:181-187.

299. Sweeney, K. G., A. Verghese, and C. A. Needham. 1985. In vitro susceptibilities of isolates from patients with $\mathrm{Bra}$ nhamella catarrhalis pneumonia compared with those of colonizing strains. Antimicrob. Agents Chemother. 27:499-502.

300. Turner, H. R., M. R. Taylor, and W. R. Lockwood. 1985. Branhamella catarrhalis endocarditis in a patient receiving hemodialysis. South. Med. J. 78:1021-1022.

301. Vaneechoutte, M., G. Verschraegen, G. Claeys, and P. Flamen. 1988. Rapid identification of Branhamella catarrhalis with 4-methylumbelliferyl butyrate. J. Clin. Microbiol. 26:12271228.

302. Vaneechoutte, M., G. Verschraegen, G. Claeys, and A.-M. Van Den Abeele. 1988. Selective medium for Branhamella catarrhalis with acetazolamide as a specific inhibitor of Neisseria spp.
J. Clin. Microbiol. 26:2544-2548.

303. Vaneechoutte, M., G. Verschraegen, G. Claeys, and A.-M. Van Den Abeele. 1990. Serological typing of Branhamella catarrhalis strains on the basis of lipopolysaccharide antigens. J. Clin. Microbiol. 28:182-197.

304. van Embden, J. D. A., B. van Klingeren, M. Dessens-Kroon, and L. J. van Wijngaarden. 1980. Penicillinase-producing Neisseria gonorrhoeae in The Netherlands: epidemiology and genetic and molecular characterization of their plasmids. Antimicrob. Agents Chemother. 18:789-797.

305. Van Hare, G. F., P. A. Shurin, C. D. Marchant, N. A. Cartelli, C. E. Johnson, D. Fulton, S. Carlin, and C. H. Kim. 1987. Acute otitis media caused by Branhamella catarrhalis: biology and therapy. Rev. Infect. Dis. 9:16-27.

306. Van Lierde, S., J. M. Puck, J. M. Campos, and S. A. Plotkin. 1985. Branhamella catarrhalis sepsis. Pediatr. Infect. Dis. J. 4:562-563.

307. Vedros, N. A. 1984. Genus I. Neisseria Trevisan 1885, p. 290-296. In N. R. Krieg and J. G. Holt (ed.), Bergey's manual of systematic bacteriology, vol. 1. The Williams \& Wilkins Co., Baltimore.

308. Véron, M., P. Thibault, and L. Second. 1959. Neisseria mucosa (Diplococcus mucosus Lingelsheim). 1. Description bactériologique et étude du pouvoir pathogène. Ann. Inst. Pasteur (Paris) 97:497-510.

309. Wald, E. R., G. J. Milmoe, A. D. Bowen, J. Ledesma-Medina, N. Salamon, and C. D. Bluestone. 1981. Acute maxillary sinusitis in children. N. Engl. J. Med. 304:749-754.

310. Wald, E. R., D. D. Rohn, D. M. Chiponis, M. M. Blattner, K. S. Reisinger, and F. P. Wucher. 1983. Quantitative cultures of middle-ear fluid in acute otitis media. J. Pediatr. 102:259261.

311. Wallace, R. J., Jr., V. A. Steingrube, D. R. Nash, D. G. Hollis, C. Flanagan, B. A. Brown, A. Labidi, and R. E. Weaver. 1989. BRO $\beta$-lactamases of Branhamella catarrhalis, and Moraxella subgenus Moraxella, including evidence for chromosomal $\beta$-lactamase transfer by conjugation in $B$. catarrhalis, $M$. nonliquefaciens, and $M$. lacunata. Antimicrob. Agents Chemother. 33:1845-1854.

312. Wardle, J. K. 1986. Branhamella catarrhalis as an indirect pathogen. Drugs 31(Suppl. 3):93-96.

313. Waters, M. J., C. L. Steinfort, and J. H. Andrew. 1985. Branhamella catarrhalis, a respiratory tract pathogen. Aust. N. Z. J. Med. 15:579-584.

314. Weiner, M., and P. D. Penha. 1990. Evaluation of Bacto TB Hydrolysis Reagent (Tween 80) for the identification of Branhamella catarrhalis. J. Clin. Microbiol. 28:126-127.

315. Welborn, P. P., C. T. Uyeda, and N. Ellison-Birang. 1984. Evaluation of Gonochek-II as a rapid identification system for pathogenic Neisseria species. J. Clin. Microbiol. 20:680-683.

316. West, M., S. L. Berk, and J. K. Smith. 1982. Branhamella catarrhalis pneumonia. South. Med. J. 75:1021-1023.

317. Whittington, W. L., R. J. Rice, J. W. Biddle, and J. S. Knapp. 1988. Incorrect identification of Neisseria gonorrhoeae from infants and children. Pediatr. Infect. Dis. J. 7:3-10.

318. Wistreich, G. A., and R. F. Baker. 1971. The presence of fimbriae (pili) in three species of Neisseria. J. Gen. Microbiol. 65:167-173.

319. Wong, V. K., and W. H. Mason. 1987. Branhamella catarrhalis as a cause of bacterial tracheitis. Pediatr. Infect. Dis. J. 6:945-946.

320. Wong, V. K., and L. A. Ross. 1988. Branhamella catarrhalis septicemia in an infant with AIDS. Scand. J. Infect. Dis. 20:559-560.

321. Wright, P. W., and R. J. Wallace, Jr. 1989. Pneumonia due to Moraxella (Branhamella) catarrhalis. Semin. Respir. Infect. 4:40-46.

322. Wüst, J., G. V. Doern, and A. von Graevenitz. 1988. Branhamella catarrhalis: fatty acid and lipopolysaccharide analysis of an atypical strain from blood culture. Diagn. Microbiol. Infect. Dis. 10:131-134.

323. Yokota, E., T. Fujii, K. Sato, M. Inoue, and S. Mitsuhashi. 1986. Purification and properties of $\beta$-lactamase produced by 
Branhamella catarrhalis. Antimicrob. Agents Chemother. 29: 696-698.

324. Youmans, G. P., P. Y. Paterson, and H. M. Sommers. 1985. The biologic and clinical basis of infectious diseases, 3rd ed., p. $67,71-72 ; 237 ; 572-579 ; 756-780$. The W. B. Saunders Co., Philadelphia.

325. Young, H., and S. S. R. Bain. 1983. Neisserial colonisation of the pharynx. Br. J. Vener. Dis. 59:228-231.

326. Young, H., A. B. Harris, and J. W. Tapsall. 1984. Differentiation of gonococcal and non-gonococcal neisseriae by the superoxol test. Br. J. Vener. Dis. 60:87-89.

327. Yourassowsky, E., M. P. Van der Linden, M. J. Lismont, and F. Crokaert. 1988. Bactericidal activity of BMY-28100 versus amoxicillin/clavulanic acid against Branhamella catarrhalis. Eur. J. Clin. Microbiol. Infect. Dis. 7:433-434.

328. Yuen, K. Y., W. H. Seto, and S. G. Ong. 1989. The significance of Branhamella catarrhalis in bronchopulmonary infection-a case-control study. J. Infect. 19:251-256.

329. Zheng, X., and Y. Cao. 1988. Beta-lactamase-producing Branhamella in Beijing, China. Pediatr. Infect. Dis. J. 7:744. 